Cornell University Law School Scholarship@Cornell Law: A Digital Repository

1999

\title{
Why the Law Hates Speculators: Regulation and Private Ordering in the Market for OTC Derivatives
}

Lynn A. Stout

Cornell Law School,1s483@cornell.edu

Follow this and additional works at: https://scholarship.law.cornell.edu/facpub

Part of the Banking and Finance Law Commons, Business Organizations Law Commons, and the Securities Law Commons

\section{Recommended Citation}

Lynn A. Stout, "Why the Law Hates Speculators: Regulation and Private Ordering in the Market for OTC Derivatives," 48 Duke Law Journal 701 (1999)

This Article is brought to you for free and open access by the Faculty Scholarship at Scholarship@Cornell Law: A Digital Repository. It has been accepted for inclusion in Cornell Law Faculty Publications by an authorized administrator of Scholarship@Cornell Law: A Digital Repository. For more information, please contact jmp8@cornell.edu. 


\title{
WHY THE LA W HATE S SPE CULATORS: REGULATION AND PRIVATE ORDERING IN THE MARKET FOR OTC DERIVATIVES
}

\author{
LYNN A. STOUT†
}

\begin{abstract}
A BSTRACT
A wide variety of statutory and common law doctrines in A merican law evidence hostility towards speculation. Conventional economic theory, however, generally views speculation as an efficient form of trading that shifts risk to those who can bear it most easily and improves the accuracy of market prices. This A rticle reconciles the apparent conflict between legal tradition and economic theory by explaining why some forms of speculative trading may be inefficient. It presents a heterogeneous expectations model of speculative trading that offers important insights into antispeculation laws in general, and the ongoing debate concerning over-the-counter (OTC) derivatives in particular.
\end{abstract}

A lthough trading in OTC derivatives is presently largely unregulated, the Commodity Futures Trading Commission recently announced its intention to consider substantively regulating OTC derivatives under the Commodity Exchange Act (CEA). B ecause the $C E A$ is at heart an antispeculation law, the heterogeneous expectations model of speculation offers policy support for the CFTC's claim

$\dagger$ Professor of Law, G eorgetown U niversity Law Center. M uch of the work on this A rticle was completed while I was a Guest Scholar at the Brookings Institution, and I am grateful to $B$ rookings for its support. E arlier versions were presented at workshops at the law schools of Cornell, Fordham, G eorgetown, $\mathrm{H}$ arvard, I owa, M ichigan, T oronto, and $\mathrm{V}$ anderbilt, and at the A nnual M eeting of the A merican Law and E conomics A ssociation. I thank the participants at those sessions for their many helpful comments. I owe a special debt to the following individuals for their guidance and insights: $G$ eorge $A$ kerlof, $M$ argaret Blair, Stephen Cohen, William Dickens, Jill Fisch, M erritt Fox, M ark Geistfeld, B ruce Hay, Jack H irshleifer, L ouis Kaplow, D onald Langevoort, H arold M aier, G eorge Martin, Martin Mayer, James OIdham, D ouglas O lin, E ric Posner, Sam R ea, Steven Shavell, Steve Thel, R andall Thomas, and William Vukowich. Finally, I am grateful to W ells E ngledow, M ark Fitzpatrick, K aren J ennings and J oseph $\mathrm{V}$ itale for their assistance in preparing this A rticle. 
of regulatory jurisdiction. This model also, however, suggests an alternative to the apparently binary choice now available to lawmakers (i.e., either regulate OTC derivatives under the CEA, or exempt them). That alternative would be to regulate OTC derivatives in the same manner that the common law traditionally regulated speculative contracts: as permitted, but legally unenforceable, agreements. By requiring derivatives traders to rely on private ordering to ensure the performance of their agreements, this strategy may offer significant advantages in discouraging welfare-reducing speculation based on heterogeneous expectations while protecting more beneficial forms of derivatives trading.

\section{TABLE OF CONTENTS}

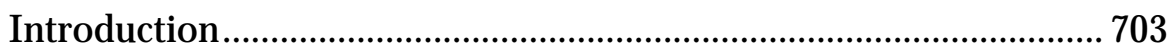

I. A ntispeculation R ules in A merican L aw ................................... 712

A. The Common Law R ule A gainst D ifference Contracts........ 713

B. Codifying the Common L aw: A ntibucketshop Statutes and the Commodity Exchange A ct........................ 721

C. A ntispeculation R ules in Insurance $L$ aw:

The D octrines of I ndemnity and I nsurable I nterest............ 724

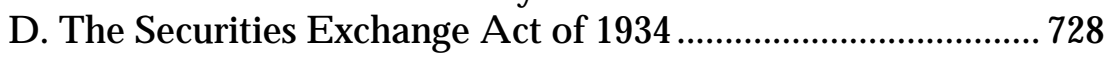

E. Summary: The Prevalence of A ntispeculation $L$ aw .............. 733

II. Conventional E conomic Theories of Speculation: The R isk

H edging and Information A rbitrage M odels ........................ 735

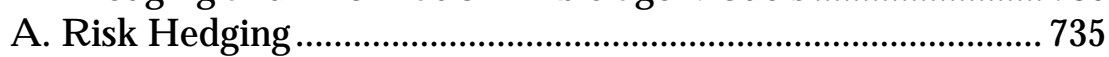

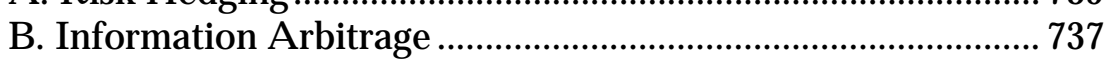

C. Summary: N ormative I mplications of

Conventional Theories......................................................... 739

III. The H eterogeneous Expectations Theory of Speculation ......... 741

A . The H eterogeneous Expectations A pproach ........................ 741

1. A $n$ Example of Trading $B$ ased on H eterogeneous

Expectations.

2. Characteristics of HE Trading: U ncertainty, Speculator-with-Speculator Trading and

Ex Post Speculator L osses.

3. E mpirical E vidence of $\mathrm{HE}$ Trading.................................. 746

4. Some $O$ bjections to the HE M odel: R ational Expectations and Trader L earning.

B. Normative I mplications of the HE M odel .............................. 751

1. HE Trading and Trader W elfare. .................................. 751 
2. HE Trading, Price A ccuracy, and Speculative B ubbles.

C. Summary: The HE M odel and the Common Law

Conception of Speculation.

IV . HE Speculation and the M arket for OTC Derivatives ............... 764

A . OTC D erivatives as O ff-E xchange Futures and O ptions ..... 765

B. The Controversy over A pplying the CE A to D erivatives..... 767

C. HE Theory and the E conomic Consequences of

D erivatives Speculation

D. D iscouraging HE Trading in Derivatives: Lessons

from the CEA

E. D iscouraging HE Trading in D erivatives: L essons

from the Common Law

F. Summary: R egulation and Private Ordering in the

$M$ arket for OTC D erivatives.

\section{INTRODUCTION}

The public disapproves of speculators. ${ }^{1}$ So, traditionally, does the law. A Ithough hostility towards speculators is so deeply woven into our nation's legal fabric that it often goes unnoticed, a remarkable variety of laws discourages people from trying to profit from shortterm price changes. Tax law, for example, favors those who hold assets for long periods over those who resell quickly. ${ }^{2}$ B oth the common law of contract ${ }^{3}$ and the Commodity Exchange A ct (CE A $)^{4}$ prohibit certain types of speculative transactions outside the confines of a regulated futures exchange. Even in the stock market, an area of economic life many regard as synonymous with speculation, federal regulations limit speculators' ability to wager on market downturns by "selling short." ${ }^{5}$ A ntispeculation rules are pervasive, appearing in

1. See For Richer, For Poorer, The Economist, Nov. 5, 1994, at 19, 20 (noting that A mericans resent financial speculators). "Speculation" can be defined as the purchase of an asset with the intent of quickly selling it, or the sale with the intent of quickly repurchasing. A more detailed analysis of the factors motivating speculative activity is offered infra in Parts II and III.

2. See infra text accompanying note 137 (discussing capital gains rules).

3. See infra Part I.A (discussing the common law rule against difference contracts).

4. See infra Part I.B (discussing the Commodity Exchange A ct's ban on off-exchange futures).

5. See infra text accompanying notes $121-30$ (discussing short sales restrictions designed 
statutes and in the common law, in doctrines ancient and new, and at the state and federal levels. ${ }^{6}$

R ecent years have witnessed the rise of a new challenge to this longstanding legal regime. That challenge is from over-the-counter (OTC) derivatives, private contracts for payments determined by the changing price of some underlying commodity or financial instrument. ${ }^{7}$ Trading in derivatives has grown dramatically since these agreements first became popular in the 1980s. In the last five years alone, estimates of the notional value ${ }^{8}$ of outstanding derivative contracts have risen from $\$ 14$ trillion to $\$ 70$ trillion ${ }^{9}$ - nearly ten times

to discourage speculation).

6. For other examples, see infra text accompanying notes 44-45 (discussing antiwagering rules), 96-109 (discussing indemnity and insurable interest rules), 118-20 (discussing the margin requirements of the Securities Exchange A ct of 1934), and 136 (discussing the champerty prohibition and trust laws' prudent person rule).

7. A derivative contract generally creates either an option or an obligation to make or to receive payments determined by some changing interest rate, financial index, or market price. See generally Richard A. Brealey \& Stewart C. Meyers, Principles of Corporate FINA NCE 711-29 (5th ed. 1996) (providing an overview of derivative instruments). For example, one common derivative is the "interest rate swap," in which one party exchanges its promise to make a series of payments at some floating rate of interest determined by market conditions in return for the other party's promise to make payments at a fixed rate. See infra text accompanying notes 243-44 (describing swaps). "Exchange traded" derivatives are standardized futures and options contracts which are traded on a regulated commodities exchange subject to the oversight of the Commodity Futures Trading Commission. See infra text accompanying notes 68-72 (discussing exchanges) and 87-95 (describing federal regulation of exchange trading). OTC derivatives, in contrast, are privately traded and often highly customized agreements that are usually negotiated between large institutions such as banks, corporations, and pension funds. See generally Thomas Lee $\mathrm{H}$ azen, Rational Investments, Speculation, or G ambling? D erivative Securities and Financial Futures and Their E ffect on the Underlying Capital M arkets, 86 NW. U. L. REV. 987, 989-91 (1992) (explaining derivatives); H enry T.C. H u, H edging Expectations: "D erivative Reality" and the $L$ aw and Finance of the Corporate Objective, 73 TEX. L. REV. 985, 996-1000 (1995) [hereinafter H u, Hedging Expectations] (same); Henry T.C. Hu, $M$ isunderstood D erivatives: The Causes of Informational Failure and the Promise of R egulatory Incrementalism, 102 Y A LE L.J . 1457, 1464-67 (1993) [hereinafter H u, M isunderstood Derivatives] (same); R oberta R omano, A Thumbnail Sketch of D erivative Securities and Their Regulation, 55 MD. L. REV. 1 (1996) (same); see also infra note 238 and accompanying text (describing the OTC market).

8. Derivatives are usually valued according to their "notional amount," meaning the market value of the assets or debt balance on which payments are based. See $\mathrm{H} \mathrm{u}$, M isunderstood D erivatives, supra note 7, at 1459 n.6.

9. See Saul S. Cohen, The Challenge of Derivatives, 63 FORDHAM L. REv. 1993, 1993 (1995) (estimating the notional value of outstanding derivatives at $\$ 14$ to $\$ 35$ trillion); Thomas A. Tormey, Note, A D erivatives Dilemma: The Treasury A mendment Controversy and the Regulatory Status of Foreign Currency O ptions, 65 FORDHAM L. REV. 2313, 2315 n.2 (1997) (estimating the global notional amount of outstanding over-the-counter derivatives in 1995 at $\$ 47.5$ trillion); Elizabeth M acD onald, FA SB M oving A head on Rule on Derivatives, W A LL ST. J., J uly 17, 1997, at A 2 (citing Chairman of the Securities and Exchange Commission A rthur C. 
the U .S. gross domestic product. ${ }^{10} \mathrm{~A}$ nd while derivatives are often described as instruments for hedging against business risks, ${ }^{11}$ they are also frequently used as vehicles for speculating on everything from fuel oil prices to home mortgage rates. ${ }^{12}$

The sudden appearance of a largely unregulated, multi-trillion dollar market in OTC derivatives accordingly highlights the need for a solid understanding of the nature and purpose of traditional antispeculation laws. ${ }^{13}$ This need is especially pressing in light of the recent announcement by the Commodity Futures Trading Commission (CFTC) of its intent to develop a comprehensive scheme to regulate derivatives under the Commodity Exchange A ct (CEA). ${ }^{14}$ The CEA is an important-if often overlooked-antispeculation law that requires most futures and option contracts to be traded only after the CFTC has approved them, and only on a regulated futures exchange where the CFTC imposes technical rules designed to deter speculative trading. ${ }^{15}$ B ecause applying the CEA to derivatives implies that OTC derivatives trading is presumptively illegal absent CFTC approval, ${ }_{1}^{16}$ the CFTC's announcement has provoked a storm of protest

L evitt's estimate of $\$ 70$ trillion); Suzanne M cG ee \& E lizabeth M acD onald, Pre-E mptive Strike by Derivatives Players, WALL ST. J., Feb. 21, 1997, at C1 (citing an estimate by an industry newsletter, Swaps M onitor, of $\$ 55$ trillion).

10. See B ureau of E conomic A nalysis, U .S. D ep't of Commerce, G ross D omestic Product: Fourth Quarter 1998 (Preliminary), News Release BEA 98-24 (Feb. 26, 1999) $<$ <ttp://www.bea.doc.gov/bea/newsrel/gdp498p.htm> (listing the current dollar 1998 U.S. GDP at $\$ 8.5$ trillion).

11. See U.S. Gen. A cCoUnting OfFICE, GA O/G GD-94-133, FInANCIAL DERIVATIVes: Actions Needed to Protect the Financial System 25 (1994) [hereinafter Ga O RePORT].

12. See id. (describing derivatives speculation); see also infra text accompanying note 245 (reporting that nearly half of derivatives traders report using derivatives for speculation).

13. See infra text accompanying note 262 (discussing how derivatives users can evade antispeculation laws).

14. O ver-the-Counter D erivatives, 63 Fed. R eg. 26,114 (1998) (to be codified at 17 C.F.R . pts. 34-35) (proposed M ay 12, 1998).

15. See infra text accompanying notes 87-95 (describing theCEA's exchange trading requirement). The CFTC has authority to exempt classes of instruments from this exchange trading requirement, and in the past it has avoided confrontation over the scope of its authority by choosing to "exempt" most financial derivatives from its oversight. See O ver-the-Counter D erivatives, 63 Fed. R eg. at 26,116-19 (discussing exemptions for swaps and hybrids). In M ay 1998 the CFTC issued a release announcing its intention to "reexamine its regulatory approach" and to revisit these exemptions. Id. at 26,115. The release raises for the first time the prospect of significant CFTC intervention in the OTC market.

16. See infra text accompanying note 255 (discussing the implications of applying the CEA to financial derivatives and objections to the CFTC's release). If the CEA were applied to OTC derivatives, the CFTC would enjoy tremendous discretion to decide which types of derivatives 
from the industry and from rival agencies. ${ }^{17}$ In response, the U.S. Congress has passed legislation that bans the CFTC from taking any action before $M$ arch $1999 .{ }^{18}$

W hat should Congress do when that legislation expires: allow the CFTC to regulate the multi-trillion dollar derivatives market, or declare these instruments exempt from the CEA 's antispeculation provisions? The answer to this question must depend in part on whether derivatives speculation is beneficial or harmful. In an earlier era, lawmakers would have viewed the sudden appearance of an enormous speculative market as a menace to the public welfare. During the nineteenth century, for example, courts routinely refused to enforce many types of speculative agreements on the grounds that speculation was contrary to public policy. ${ }^{19}$ Legislatures shared this negative perception of the effects of speculation well into the twentieth century; both the Securities Exchange A ct of 1934 and the Commodity Exchange A ct of 1936 were passed in large part to temper the perceived problems of "excessive" speculation in corporate stocks and in commodities futures and options. ${ }^{20}$

could be traded. See infra text accompanying notes 280-83 (describing how the CFTC determines which contracts may be traded).

17. See CFTC Seeks Public Comment as it R eexamines O versight of OTC M arket, $30 \mathrm{Sec}$. Reg. \& L. Rep. (BNA), at 721 (M ay 8, 1998) (discussing the CFTC's announcement and the reaction to it from the Treasury, Federal R eserve Chairman A lan G reenspan, and the Securities and Exchange Commission); The Financial M arkets R eassurance A ct of 1998, H.R. 4507, 105th Cong. (1998) (limiting, if passed, the CFTC's authority to alter the regulation of swaps and certain other derivatives under the $\mathrm{CEA}$ ); House $\mathrm{Ag}$ Chair Introduces Bill to Curtail CFTC's A ctivity in OTC D erivatives M arket, 30 Sec. Reg. \& L. Rep. (BNA), at 1197 (A ug. 7, 1998) (discussing the bill) [hereinafter Chair Introduces Bill]; House, Senate Committees to H old J uly OTC Derivatives H earings, $30 \mathrm{Sec}$. R eg. \& L. Rep. (BNA ), at 1057 (J uly 10, 1998) (discussing the CFTC's M ay 1998 release and the reactions to it); A aron Lucchetti \& M ichael Schroeder, CFTC to Review OTC D erivatives M arket, W A LL ST. J., M ay 8, 1998, at C1 (same); Timothy L. O 'B rien, A Federal Turf War over Derivatives Control, N.Y. TIMES, M ay 8, 1998, at D 3 (same).

18. See O mnibus Consolidated and E mergency Supplemental A ppropriations A ct, 1999, Pub. L. N o. 105-277, § 760(a)(3), 112 Stat. 2681 (West, WE ST L A W) (imposing a "restraint period" to expire M arch 30, 1999).

19. See infra Part I.A (describing the common law rule against difference contracts); Part I.C (discussing indemnity and insurable interest rules); text accompanying note 136 (discussing the champerty doctrine). This judicial hostility toward speculators was based on the perception that speculators caused specific economic harms. In particular, judges condemned speculation for being "nonproductive," for causing destabilizing price "bubbles," and for impoverishing speculators themselves. For a more detailed discussion, see infra text accompanying notes 5462.

20. See infra text accompanying notes $83-86$ (discussing the history of the CEA ), 112-16 (explaining the origins of the SE A). 
M ore recently, however, the idea that speculation is harmful has lost favor. Conventional economic wisdom now holds that speculation-whether in stocks, real estate, or derivatives-is economically efficient because it shifts risk to those who can bear it most easily and helps market prices more accurately reflect underlying forces of supply and demand. ${ }^{21}$ Thus, champions of derivatives have praised them as useful financial "innovations" that reduce risk and improve market pricing, while critics have focused not on derivatives' use for speculation, but on the perceived problem of "systemic risk" - that is, the chance that a derivatives trading disaster that drives one firm into bankruptcy could trigger a chain reaction of failures at other firms. ${ }^{22}$ The modern notion that speculation serves efficiency has undermined the claim that making derivatives subject to the CEA 's antispeculation rules serves any useful purpose.

$Y$ et economic reasoning itself cautions against simply dismissing antispeculation laws as the mistaken products of ignorance and envy. A $n$ important strain of the law and economics literature argues that the common law generally favors efficient rules. ${ }^{23} \mathrm{M}$ any contemporary antispeculation laws, including the $C E A$, can trace their roots back to the earliest days of the common law. ${ }^{24}$ These origins hint that

21. See infra Part II.A-B (discussing the risk hedging and information arbitrage theories of speculation).

22. See infra text accompanying note 268 (discussing systemic risk). This focus on systemic risk appears to provide little policy support for the CFTC's claim of jurisdiction over derivatives.

23. A n extensive literature argues that because inefficient rules by definition impose higher social costs, they tend to be challenged more often, creating a tendency for the common law to evolve toward efficient rules without regard to the desires of judges or litigants. See, e.g., George L. Priest, The Common L aw Process and the Selection of Efficient Rules, $6 \mathrm{~J}$. LEGA L STU D. 65, 72 (1977) (finding that “[i]nefficient rules 'perish' because they are more likely to be reviewed"); Paul H. Rubin, Why is the Common Law Efficient?, 6 J. LEGAL STUD. 51, 53-57 (1977) (same); see also R obert Cooter \& L ewis K ornhauser, Can Litigation Improve the L aw Without the H elp of J udges?, 9 J . LEGA L STUD. 139, 156-57 (1980) (discussing common law efficiency and arguing that litigation will have a "moderate influence on the persistence of good rules... without judicial insight"). A second strand of argument suggests that the common law tends to be efficient because judges, as disinterested parties, are more likely to select efficient rules than are legislatures beholden to special interests. See, e.g., RICHARD A. POSNER, ECONOMIC ANALYSIS OF LAW 569-70 (5th ed. 1998) (arguing for the relative efficiency of judge-made law); L ynn A. Stout, Strict Scrutiny and Social Choice: A $\mathrm{E}$ conomic Inquiry into Fundamental Rights and Suspect Classifications, 80 G E O. L.J. 1787, 1831-34 (1992) (same).

24. See, e.g., infra text accompanying notes 35-45 (discussing the rule against difference contracts); 96-109 (discussing indemnity and insurable interest rules); 136 (discussing champerty prohibition); 43-45 (discussing antiwagering rules); and note 136 (discussing the prudent person rule). 
antispeculation rules actually may serve an important, if generally unrecognized, efficiency function.

This A rticle seeks to shed light on the apparent conflict between modern economic theory and the legal tradition of antispeculation rules by inquiring more closely into the theoretical foundations of the modern notion that speculation is efficient. Contemporary economic theory generally emphasizes two explanations for speculative trading: the risk hedging model, which describes speculators as traders who profit by accepting risk from more risk-averse "hedgers," and the information arbitrage model, which posits that speculators invest in predictive information that allows them to trade at an advantage with less well informed consumers and producers. ${ }^{25} \mathrm{~B}$ oth provide plausible explanations for why someone might purchase an asset for no other purpose than to resell it, and both likely explain many trades. M oreover, both theories suggest that speculative trading promotes allocative efficiency, either by increasing the trading parties' net welfare (risk hedging), or by improving the accuracy of market prices (information arbitrage). ${ }^{26}$ This explains why students of economics tend to regard speculators as misunderstood capitalist heroes.

$Y$ et the conventional risk hedging and information arbitrage models of speculation may paint an incomplete and inaccurate portrait of speculative markets. This A rticle argues that any full understanding of speculation also must take account of differences in individuals' subjective expectations as a reason for trading. This heterogeneous expectations ( $\mathrm{HE}$ ) approach can explain a number of otherwise mysterious market phenomena that have troubled scholars who rely on the risk hedging and information arbitrage theories. More importantly, it suggests that speculation may not be nearly so benign a phenomenon as is often assumed. Whereas trading driven by risk hedging and information arbitrage generally increases the net welfare of the trading parties and improves the accuracy of market prices, trading driven by heterogeneous expectations produces opposite results: it reduces trader welfare and can distort prices.

25. See infra Part II (discussing the risk hedging and information arbitrage theories).

26. "A llocative efficiency" refers to the increase in social welfare that comes from allocating society's scarce resources to those who value them most highly, and costs to those who find them least burdensome. See POSNER, supra note 23, at 12-17 (discussing allocative efficiency). E conomists recognize other types of efficiency as well. See, e.g., BREA LEY \& MEYERS, supra note 7, at 323-36 (discussing "market efficiency" in setting accurate prices that incorporate all available information); see also infra text accompanying note 153 (discussing "informational" or "pricing" efficiency). 
The HE model of speculation accordingly carries important policy implications for speculative markets, including the market for derivatives. $\mathrm{H}$ igh-profile trading disasters of the sort suffered by LongTerm Capital Management, Gibson Greetings, Procter \& Gamble, and O range County, California, amply illustrate the risks that derivatives speculation can pose for individual traders. ${ }^{27}$ The $\mathrm{HE}$ model predicts, in addition, that derivatives speculation can harm the economy as a whole. A dding the insights of the HE model to those of the risk hedging and information arbitrage theories suggests that the multi-trillion dollar derivatives market may be a source of great efficiency gains-or great losses.

To maximize derivatives' benefits while minimizing their costs, we need legal rules that protect beneficial forms of trading while discouraging inefficient transactions. O ne way to do this might be to alIow the CFTC to apply the CEA to derivatives. This approach would force most market participants to do their trading on organized futures exchanges, where the CFTC requires traders to demonstrate that their contracts serve a useful economic purpose beyond "mere speculation." ${ }^{28}$ The HE model suggests an intriguing alternative to this "government gatekeeper" strategy, however. That alternative would be to permit derivatives trading outside the regulated exchanges while amending the CEA to return to the common law rule that viewed off-exchange derivatives-once known as "difference contracts" - as permissible, but legally unenforceable, transactions. By requiring off-exchange traders to rely on private ordering rather than courts to enforce their agreements, this counterintuitive approach may discourage welfare-reducing speculation while protecting more beneficial forms of trading.

27. See $G$. B ruce K necht, D erivatives $L$ ead to $H$ uge $L$ oss in Public Fund: California's O $r$ ange County has L ost $\$ 1.5$ Billion in Aggressive Strategy, W ALL ST. J., D ec. 2, 1994, at A 3 (describing O range County's derivatives losses); Steven Lipin, B ankers Trust Sued on D erivatives, W A LL ST. J., Sept. 13, 1994, at C1 (describing G ibson G reetings Inc.'s reported $\$ 23$ million loss from trading interest rate swaps); A nita Raghavan \& M itchell Pacelle, To the Rescue? A H edge Fund Falters, so the F ed Persuades Big Banks to A nte Up, W A LL ST. J ., Sept. 24, 1998, at $A 1$ (describing L ong-T erm Capital M anagement's losses due to derivatives trading); B ankers Trust: Shamed A gain, THE ECONOMIST, Oct. 7, 1995, at 87 (describing Procter \& Gamble's $\$ 195$ million loss trading in swap contracts).

28. See infra text accompanying notes 87-95 (discussing the exchange trading requirement of the CEA). As an alternative, would-be derivatives traders would have to appeal to the CFTC for an exemption from the exchange trading requirement. See supra note 15 (discussing the CFTC's authority to issue exemptions). 
The analysis proceeds as follows. Part I provides an overview of A merican antispeculation law by exploring four instrumental examples of antispeculation rules: (1) the common law rule against difference contracts, an important precursor of many modern antispeculation doctrines; (2) the Commodity Exchange A ct, which provides the basis for the CFTC's claim of jurisdiction over derivatives; (3) the doctrines of indemnity and insurable interest, two fundamental principles of insurance law that are often explained as responding to problems of moral hazard but which also have antispeculation goals; and (4) the margin requirements and short sales restrictions of the Securities Exchange A ct of 1934. These rules illustrate how A merican law systematically discourages speculation and confines it-or at least, confined it before the arrival of derivatives-primarily to the securities markets and the organized futures exchanges.

Part II reviews the risk hedging and information arbitrage models of trading. The risk hedging model describes speculators as relatively risk-neutral traders who earn profits by dealing with hedgers who pay them to assume the risk of future price changes. B ecause both sides to a hedging deal regard themselves as better off after trading than they were before, risk hedging is thought to increase traders' net welfare. In contrast, the information arbitrage model describes speculators as traders who invest in information about future prices that allows them to deal on advantageous terms with others in the market who are less well informed. A lthough information arbitrage is not necessarily mutually beneficial, arbitrageurs' trades tend to increase the accuracy of market prices as barometers of underlying supply and demand. Both models accordingly suggest that speculation serves allocative efficiency, albeit in different ways. The net result has been a strong presumption among theorists that speculation is beneficial.

Part III presents the heterogeneous expectations model of speculative trading and demonstrates how it provides theoretical support for the traditional legal hostility towards speculators. The $\mathrm{HE}$ model rests on the premise that, even when traders share identical attitudes toward risk and willingness to invest in information, they may form different beliefs about the future if they acquire different information. Although most theoretical discussions of speculation neglect the role this kind of subjective disagreement can play in inspiring trading, a notable exception can be found in the work of the 
economist Jack Hirshleifer, who has modeled speculative markets driven by what he terms "differential beliefs." ${ }^{29}$ In the two decades since Hirshleifer's papers on speculation were published, however, the implications of his model have gone largely unrecognized and undeveloped. ${ }^{30}$ Part III revives $\mathrm{H}$ irshleifer's approach and expands upon it by exploring some of its striking normative implications. In particular, the HE model contradicts the risk hedging model's claim that speculation improves trader welfare, and also undermines the information arbitrage model's claim that speculation makes prices more accurate by suggesting that $\mathrm{HE}$ speculation generally does not promote price accuracy and under some conditions can actually distort prices.

Part IV reviews the impending legislative battle over derivatives and considers some lessons the $\mathrm{HE}$ model may offer lawmakers faced with the task of deciding whether and how to regulate derivatives trading. B ecause regulators have found it difficult to understand and to articulate the policy problems associated with derivatives speculation, the debate thus far has been strongly flavored by a presumption that economic theory unreservedly champions derivatives trading. Once the insights of the $\mathrm{HE}$ model are added to those of the risk hedging and information arbitrage theories, however, it becomes apparent that one of the greatest regulatory challenges posed by derivatives is how to protect beneficial forms of trading while discouraging welfare-reducing transactions. L awmakers presently appear to face a binary choice: either apply the CEA to financial derivatives, or exempt them. The first approach makes trading presumptively illegal absent CFTC approval, and may therefore discourage beneficial risk hedging and information arbitrage transactions. The second strategy, however, invites excessive HE speculation. Part IV explores an alternative: amend the CEA to return to the common law rule that treated off-exchange derivatives as unenforceable, but not criminal, transactions. This approach would reinforce the CFTC's regulatory role by requiring derivatives users who want their contracts to be le-

29. See infra note 165 and accompanying text. Hirshleifer's work on speculation should not be confused with his influential earlier piece on the welfare effects of information arbitrage. See J ack H irshleifer, The Private and Social Value of Information and the Reward to Inventive A ctivity, 61 A M. E CON. REV. 561 (1971) [hereinafter H irshleifer, Information and Invention]; see also infra note 154 and accompanying text (discussing the implications of $\mathrm{H}$ irshleifer's 1971 article).

30. See infra text accompanying note 165 and Part III.A .4 (discussing H irshleifer's model and possible reasons why it has not attracted much attention). 
gally enforceable to do their trading on organized futures exchanges, subject to the CFTC's substantive review. At the same time, offexchange trading could still flourish. Outside the regulated exchanges, however, traders would have to rely on reputation, rather than the coercive power of the state, to ensure the performance of their agreements. A s will be seen, this time-honored strategy may harness the phenomenon of private ordering in a fashion that discourages welfare-destroying speculation while preserving more beneficial forms of trading.

\section{A NTISPECULATION RULESIN A MERICAN LAW}

To some observers, the claim that the law discourages speculation at first may seem implausible. Speculative trading appears to be the order of the day on stock exchanges like the N ew Y ork Stock Exchange, and on commodities futures exchanges like the Chicago B oard of Trade, not to mention the burgeoning derivatives market. H ow then can the law be hostile to speculators?

The answer lies in recognizing that speculators' presence in such highly visible but limited arenas obscures their relative absence elsewhere. In theory, there is no need for speculators to limit themselves to trading corporate securities and those relatively few commodities contracts officially listed for trading on an organized futures exchange. They also could wager on the future prices of plastic surgery, narrow ties, Manhattan condos, popular television shows, and law school graduates. ${ }^{31}$ In practice, speculation in such goods and services is rare. The reason can be traced to a network of obscure but impor-

31. This A rticle focuses on the phenomenon of speculation, which can be understood as a form of disagreement-based wagering on future market prices. See infra Part III.A.1-2 (describing the heterogeneous expectations model of speculative trading). Individuals who believe that they can make superior predictions for the future can also try to profit from others' subjective disagreement by placing wagers on the outcomes of horse races, card games, and sporting events. This latter type of speculation is more commonly known as "wagering" or "gambling," and like speculative trading in markets, it traditionally has been subject to severe legal restraints. See infra notes 43-45 and accompanying text (discussing the regulation of wagering). A lthough the heterogeneous expectations model of speculation may offer a variety of insights into the nature and appropriate regulation of disagreement-based wagering, the market for gambling probably differs significantly from the market for speculative trading. For example, gamblers who participate in games based on pure luck, such as slot machines or lotteries, may well share homogeneous expectations regarding the probability of winning, and smallstakes gambling at race tracks or in glitzy casinos may provide significant recreational benefits. A discussion of the gambling market accordingly lies beyond the scope of this A rticle. 
tant legal doctrines that severely limit speculators' role in most markets.

O ne of the most fundamental of these doctrines is the common law requirement that speculators who want to wager on prices through futures and options agreements have to make and accept delivery of the goods and services they trade. A Ithough few contemporary legal scholars seem aware of this rule, it persists in a variety of modern forms, most notably in insurance law ${ }^{32}$ and the Commodity Exchange $A$ ct. $^{33}$ Its net effect is to confine speculation primarily to regulated commodities futures exchanges, which are exempt from the general rule, and to the corporate securities market, where delivery is relatively easy and inexpensive. Even in these markets, moreover, speculators who seek short-term profits must run an obstacle course of margin requirements, ${ }^{34}$ position limits, ${ }^{35}$ short sales restrictions, ${ }^{36}$ capital gains rules, ${ }^{37}$ and other technical regulations that have both the purpose and the effect of deterring speculative trading. The arcana of modern tax, securities, and commodities law provide a second important curb on speculation.

The net result is a legal system that works with surprising consistency to channel our nation's economic energy toward the actual production and distribution of goods and services, and away from the pursuit of short-term trading profits. In illustration, the discussion below considers some important examples of antispeculation rules drawn from both statutes and common law. These rules suggest a pattern of legal antipathy toward speculators that springs from the longstanding belief that speculation wreaks economic harm because it is nonproductive, distorts market prices, and impoverishes speculators themselves.

\section{A. The Common $L$ aw Rule A gainst $D$ ifference Contracts}

O ne of the earliest and most important examples of antispeculation law can be found in the common law doctrine that shall be referred to below as "the rule against difference contracts." D ifference

32. See infra Part I.C (discussing indemnity and insurable interest doctrines).

33. See infra text accompanying notes 87-91 (discussing the CEA's exchange trading requirement).

34. See infra text accompanying notes 118-20 (discussing margin requirements).

35. See infra text accompanying note 95 (discussing position limits).

36. See infra text accompanying notes $121-25$ (discussing short sales restrictions).

37. See infra text accompanying notes 137-39 (discussing capital gains rules). 
contracts were close cousins to futures (contracts for the sale of goods for future delivery) and options (agreements granting one party the right but not the obligation to buy or sell at a specified price at or before some predetermined future date).$^{38}$ In a difference contract, however, the contracting parties would agree to perform not by actually delivering the good that was the subject of the contract, but by paying the difference between the contract price and the market price at the time of performance. Thus a "seller" who didn't own wheat and a "buyer" who didn't want wheat might have entered a difference contract for one ton of wheat at a contract price of $\$ 1,000$ per ton, to be settled in six months. If at the end of six months the market price for wheat had risen to $\$ 1,200$ per ton, the seller would pay the buyer $\$ 200$. If the price had dropped to $\$ 900$ per ton, the buyer would pay the seller $\$ 100$. In either case, no wheat would actually change hands. ${ }^{39}$

The common law regarded difference contracts as legally unenforceable on grounds of public policy. ${ }^{40}$ A s the U nited States Supreme Court described the rule in the 1884 case of I rwin v. Williar: ${ }^{41}$

The generally accepted doctrine in this country is . . . that a contract for the sale of goods to be delivered at a future day is valid, even though the seller has not the goods, nor any other means of getting them than to go into the market and buy them; but such a contract is only valid when the parties really intend and agree that the goods are to be delivered by the seller and the price to be paid by the buyer; and, if under guise of such a contract, the real intent be merely

38. See William F. Sharpe et al., InVestments 916, 923 (6th ed. 1998) (defining futures and options); $\mathrm{H}$ azen, supra note 7 , at 989-90 (same).

39. This is an example of a futures contract performed by settling differences. In the case of an options contract, the buyer might purchase the right to be paid the difference between the contract price for one ton of wheat and the prevailing market price for wheat during some future time period. Such a right would be valuable only if the market price for wheat rose above the contract price during the option period.

40. See, e.g., State v. Stripling, 113 A la. 120, 123-24 (1896) (dictum) (stating that difference contracts have been "the source of great injury to morals"); C unningham $v$. National Bank, 71 Ga. 400, 403-05 (1882) (stating that difference contracts are "fraught with . . . evil consequences" and are hence contrary to public policy); R umsey v. Berry, $65 \mathrm{M} \mathrm{e.} \mathrm{570,} 574$ (1876) (dictum) (emphasizing that difference contracts are "against public policy, and not only void, but deserving of the severest censure"); Cassard v. H inmann, 14 H ow. Pr. 84, 90-91 (N.Y. Sup. Ct. 1856) (invalidating a difference contract under a law prohibiting betting and gaming for fear that speculative contracts would become "as common as legitimate dealing"); B rua's A ppeal, 55 Pa. 294, 298-99 (1867) (holding invalid promissory notes for debts owed on a speculative contract on the grounds that "[a]ll gambling is immoral" and leads to misery and suffering).

41. 110 U .S. 499 (1884). 
to speculate in the rise or fall of prices, and the goods are not to be delivered, but one party is to pay to the other the difference between the contract price and the market price of the goods at the date fixed for executing the contract, then the whole transaction constitutes nothing more than a wager, and is null and void. ${ }^{42}$

This rule against "settling differences" offers a variety of useful insights into antispeculation law. First, it suggests a perceived link between speculation and gambling, ${ }^{43}$ a link that is considered again in Part III. ${ }^{44}$ Common law courts regarded speculation as a type of wagering rather than a useful form of economic commerce. Thus difference contracts, like private wagers, were declared legally unenforceable. ${ }^{45}$

A second striking aspect of the rule is the strategy it employed to discourage speculation. In effect, the rule forced speculators who wanted their contracts to be enforceable to trade in the underlying "spot market," ${ }^{46}$ making and accepting delivery of the goods they bought and sold. The rule thus imposed a "tax" on speculators by requiring them to incur expenses that they could have avoided if difference agreements had been enforceable. For example, spot market speculators would incur substantial transportation expenses trading in commodities that were bulky (wheat), obstinate (livestock), or dif-

42. Id. at 508-09 (emphasis added).

43. See Stripling, $113 \mathrm{~A}$ la. at $123-24$ ("O ne of the most pernicious forms of gambling is 'speculating in futures,' on margins, and settling differences only."); C unningham, $71 \mathrm{G}$ a. at 403 (declining to enforce difference transaction and confessing that "[i]f this is not a speculation on chances, a wagering and betting between the parties, then we are unable to understand the transaction").

44. The heterogeneous expectations model suggests that the difference between speculators and certain gamblers is simply that speculators disagree in their predictions for market prices, while gamblers disagree in their predictions for horse races, political elections, and other nonmarket events. See infra text accompanying note 164 (describing gambling as disagreementbased trading). Thus antiwagering laws may be another form of antispeculation rule.

45. Private wagers have been invalid and unenforceable since the earliest days of A merican common law. See Irwin, 110 U.S. at 509-10 (discussing the illegality of wagering); NA tiOnA L INST. Of LAW ENFORCEMENT AND CRIMINAL JUSTICE, U.S. DEP'T OF JUSTICE, THE DEVELOPMENT OF THE LAW OF GAMBLING: 1776-1976 62 (1977) [hereinafter THE LAW OF GAMBLING] (same). Even in those limited venues where wagering is now allowed (e.g., licensed casinos and pari-mutuel racetracks), gambling remains a highly taxed and highly regulated industry.

46. In the "spot" market, a sale is followed by the immediate delivery of the commodity in question. See SHARPE ET AL., supra note 38, at 929. In the "cash forward" market, delivery is delayed by agreement. See BARBA RA L. CARR OLL, FINANCIA L FUTURESTRA DING 175 (1989). For convenience, this A rticle uses the phrase "spot market" to describe both sorts of transactions. 
ficult to transfer securely (gold bullion). Requiring delivery also forced speculators to bear the costs and risks of "carrying" goodsstoring, protecting, maintaining, even feeding and watering themduring the period between purchase and sale. Finally, the rule reduced speculators' liquidity by tying up their wealth in inventory. ${ }^{47}$ For some forms of property, these transaction costs would be relatively small: baseball cards and corporate stocks could each be spot traded relatively cheaply. ${ }^{48}$ In most markets, however, delivery greatly increased the cost of taking a speculative position. ${ }^{49}$ The rule against difference contracts thus raised a significant hurdle to speculation in most goods and services. ${ }^{50}$

A third remarkable feature of the rule against difference contracts is that is was explicitly grounded in public policy. Some cases phrased this policy in moral terms, ${ }^{51}$ describing difference contracts as "tainted and poisoned" ${ }^{52}$ and "the source of great injury to morals." ${ }^{53}$ Other cases, however, justified the rule as necessary to temper speculation's supposedly pernicious economic consequences. In other words, speculation was thought to harm not just morals, but markets.

Concern for speculation's economic effects was reflected in three curious charges courts lodged against speculators in difference con-

47. Speculators could reduce carrying costs and restore liquidity through measures such as buying insurance on warehoused inventory, or taking out loans secured by inventory. These strategies involve their own costs, however.

48. Spot market speculation in baseball cards and stocks accordingly is relatively attractive. See infra note 113 and accompanying text (discussing the prevalence of speculation in the stock market).

49. Consider, for example, the expenses associated with spot trading in real estate, livestock, or plastic surgeons' services.

50. Buyers and sellers who trade goods and services because they grow them, produce them, consume them, or use them in a manufacturing process must also incur transportation, storage, and liquidity costs. These sorts of traders, however, both expect and desire sales contracts that call for physical delivery: a milling company can only turn wheat into flour if the wheat is delivered. Speculators, in contrast, would prefer to avoid delivery by structuring their transactions through futures and options contracts that are ultimately settled simply by paying the difference between the contract price and the market price at time of settlement.

51. See, e.g., State v. Stripling, 113 A la. 120, 123-24 (1896) (describing difference contracts as injurious to public morals); Cunningham v. National Bank of A ugusta, $71 \mathrm{Ga} .400,404$ (1882) (stating that difference contracts are "immoral" and "fraught with . . . evil consequences"); Rumsey v. Berry, 65 Me. 570, 574 (1876) (stating that difference contracts are "deserving of the severest censure"); see also E dwin W. Patterson, H edging and Wagering on Produce Exchanges, 40 Y A LE L.J . 843, 852 (1931) (citing "moral sentiments of the community" as a source of judicial hostility towards difference contracts).

52. Cunningham, $71 \mathrm{G}$ a. at 403 .

53. Stripling, $113 \mathrm{~A}$ la. at 124 . 
tract cases. The first was that speculators were nonproductive. ${ }^{54}$ Thus judges refused to enforce difference contracts on the grounds that speculation "promote[d] no legitimate trade" ${ }^{55}$ and "discourage[d] the disposition to engage in steady business or labor . . ." ${ }^{56}$ This argument seems to have been based on a perception that speculators' profits came out of the pockets of the unfortunates who traded with them, so that speculators were social parasites who fed on others' labor while themselves contributing nothing to the community. ${ }^{57}$

A second economic concern mentioned in difference contract cases arose from speculators' supposedly harmful effects on market prices. Speculators were associated with market instability and especially the puzzling phenomenon of price bubbles. ${ }^{58}$ Thus judges condemned speculators because their trading "agitate[d] the markets" ${ }^{59}$ and "derang[ed] prices to the detriment of the community." 60

54. See Patterson, supra note 51, at 853 (arguing that many judges and commentators are hostile toward difference contracts because they consider the contracts unproductive activity); cf. THE LAW OF GAMBLING, supra note 45, at 97 ("The public remains wary of speculative activities whose appeal lies in the prospect of 'getting rich quick' ... without any physical or intellectual effort."). Common law courts similarly condemned wagering as nonproductive. See id. at 62; see also, e.g., A mory v. Gilman, 2 M ass. 1, 11 (1806) (Sedgwick, J., concurring) ("The practice of gaming ... withdraws the exertions of men from useful pursuits.").

55. M elchert v. A merican U nion Tel. Co., 11 F. 193, 195 (D . I owa 1882).

56. J usth v. Holliday, 13 D.C. (2 M ackey) 346, 349 (1883).

57. A s the Supreme Court of Pennsylvania described it:

A nything which induces men to risk their money or property without any other hope of return than to get for nothing any given amount from another, is gambling, and demoralizing to the community, no matter by what name it may be called. ... [T] ]he losing party has received just as much for the money parted with in the one case as the other, viz.; nothing at all. The lucky winner of course is the gainer, and he will continue so until fickle fortune in due time makes him feel the woes he has inflicted on others.

B rua's A ppeal, 55 Pa. 294, 298-99 (1867).

58. This association between speculators and price bubbles is also apparent in section 2 of the Securities Exchange A ct of 1934, which states that "securities ... are susceptible to . . . excessive speculation, resulting in sudden and unreasonable fluctuations in . . . prices." 15 U .S.C. $\S 78 b$ (1994).

59. Melchert, $11 \mathrm{~F}$. at 195 (also identifying "sudden fluctuations in values" as the "illegitimate progeny" of speculation).

60. J usth, 13 D.C. (2 M ackey) at 349; see also K irkpatrick \& L yons v. B onsall, 72 Pa. 155, 158 (1872):

[V ]entures upon prices invite men of small means to enter into transactions far beyond their capital, which they do not intend to fulfil, and thus the apparent business in the particular trade is inflated and unreal, and like a bubble needs only to be pricked to disappear; often carrying down the bonâ fide dealer in its collapse. 
A third apprehension judges voiced in difference contracts cases related to speculation's supposedly deleterious effects on speculators themselves. By offering an easy way to bet on market prices, difference agreements were thought to tempt people into accepting unreasonable risks. ${ }^{61}$ The sad result, according to some cases, was to "fill the cities with . . . bankrupt victims" of speculative fever, along with their impoverished dependents. ${ }^{62}$

Parts II and III reconsider these arguments and explore how they may or may not be supported by economic theory. For the moment, it should be noted that even while judges in difference contract cases condemned speculation generally, they also appeared to recognize that some forms of difference contract trading might be socially beneficial. This intuition was reflected in two important exceptions to the general rule of unenforceability: the exception for indemnity agreements, and the exception for exchange-traded futures.

While generally refusing to enforce contracts of sale not intended to be settled by delivery, common law courts applied an exception in cases where one party to a difference contract could demonstrate that the contract served a legitimate hedging function. Such a party would have to show that at the time she entered the contract, she held an economic interest that would be damaged by the happening of the very same event that would allow her to profit under the contract. ${ }^{63}$ Thus, for example, a plaintiff seeking to enforce a difference agreement that allowed her to profit if wheat prices fell might demonstrate that she held a wheat inventory, the value of which would be damaged by a price decline. ${ }^{64}$ Because such a contract would offset a preexisting source of loss rather than creating an op-

61. See J usth, 13 D.C. (2 M ackey) at 348-49 ("[T ]he inevitable effect of [difference contracts] is to encourage wild speculations ....."); Cunningham v. N ational Bank, $71 \mathrm{G} \mathrm{a.} \mathrm{400,} 404$ (1882) (emphasizing that speculation encourages unreasonable risk with resulting losses); Brua's A ppeal, $55 \mathrm{~Pa}$. at 299 (stating that speculation “induces men to risk their money or property" and results in bankruptcies); see also Patterson, supra note 51, at 853 (describing the judicial perception that speculation leads to the "impoverishment of losers and their dependents").

62. J usth, 13 D.C. ( 2 Mackey) at 349. A $n$ increase in the incidence of financial ruin was thought to spawn its own social ills. See Cunningham, $71 \mathrm{G}$ a. at 403 (declaring that speculation results in "bankruptcies, defalcations of public officers, embezzlements, forgeries, larcenies, and death"); B rua's A ppeal, $55 \mathrm{~Pa}$. at 299 (positing that speculation contributes to "failures and embezzlements by public officers, clerks, agents and others acting in fiduciary relations").

63. See Patterson, supra note 51 , at $851-52$.

64. See id. 
portunity for gain, courts recharacterized these types of contracts as enforceable "indemnity" agreements. ${ }^{65}$

The indemnity exception to the rule against difference contracts suggests that judges recognized that difference agreements could be used for insurance as well as for gambling. ${ }^{66} \mathrm{~A}$ the same time, the fact that the indemnity exception was an exception implies a judicial perception that many difference contracts didn't insure against a preexisting risk. In other words, risk hedging was perceived as the exception- not the rule-in difference contract trading. ${ }^{67}$

The notion that some difference contracts served a useful hedging function while others did not also underlay the second important exception to the rule against difference contracts: the exception for exchange-traded futures. To finance theorists, any contract of sale for future delivery is a "future." ${ }^{68}$ In legal terminology, however, the word "future" is sometimes interpreted more narrowly to apply only to the highly standardized contracts for future delivery that are traded in "pits" on organized commodities exchanges such as the Chicago Board of Trade. ${ }^{69}$ Traders who buy exchange-traded futures are technically entitled to demand delivery. A s a practical matter, however, most exchange-traded futures are settled through an "offset" process in which one party to the contract extinguishes her obligation by reentering the pit and purchasing a second, offsetting contract. Thus a trader obligated to sell 100 bushels of wheat on $M$ ay 1 might offset her obligation by purchasing a contract to buy 100 bushels on $\mathrm{M}$ ay 1 , absorbing the price difference as profit or loss. ${ }^{70}$

In economic substance, an offset futures contract looks very much like a difference agreement. Courts nevertheless adopted very differing attitudes toward the two types of transactions. A s J ustice $\mathrm{H}$ olmes explained in the 1905 case Board of Trade of Chicago v. Christie Grain \& Stock Co.:

\footnotetext{
65. Seeid.
}

66. See infra text accompanying notes 105-09 (exploring the relationship between speculation and insurance).

67. This contradicts the risk hedging model's prediction that speculators will always trade against hedgers. See infra Part III .A (discussing the risk hedging model of speculation).

68. See sources cited supra note 38.

69. See generally W illiam L. Stein, The Exchange-Trading R equirement of the Commodity Exchange A ct, 41 V A ND. L. REV . 473, 488 (1988) (discussing the legal definition of futures).

70. See J ohn Buchovecky, Comment, The Future of L everage Contract Trading U nder the Futures Trading A ct of 1986, 37 A M . U. L. R EV . 157, 159 (1987) (discussing offset).

71. 198 U.S. 236 (1905). 
There is no doubt that the large part of those [futures] contracts is made for serious business purposes. Hedging, for instance, as it is called, is a means by which collectors and exporters of grain or other products, and manufacturers who make contracts in advance for the sale of their goods, secure themselves against the fluctuations of the market by counter contracts for the purchase or sale, as the case may be, of an equal quantity of the product, or of the material of manufacture. .... It seems to us an extraordinary and unlikely proposition that the dealings which give its character to the great market for future sales in this country are to be regarded as mere wagers .... A set-off is in legal effect a delivery. We speak only of the contracts made in the pits, because in them the members are principals. ${ }^{72}$

A s this language suggests, courts perceived organized futures markets as serving primarily the bona fide insurance needs of commodities suppliers and consumers, rather than the passions of speculators. ${ }^{73}$ To preserve these benefits, ${ }^{74}$ courts accordingly declared offset to be a form of delivery distinguishable from the forbidden practice of settling differences. ${ }^{75}$ The technical distinction between "offset" and "settling differences" provides an interesting example of an early attempt to devise a legal rule that discouraged harmful speculation while protecting more valued forms of trading. ${ }^{76}$ It also laid the foundation for the primary legal regime governing "difference contract" trading today: the Commodity Exchange A ct of 1936.

72. Id. at 249-50.

73. While in Holmes's day most organized futures trading may have reflected hedging by commodities consumers and suppliers, this may no longer be true. See CARROLL, supra note 46 , at 55 (estimating that commercial hedging accounts for only $20 \%$ of daily trading volume in financial futures).

74. Holmes's opinion also seems to recognize, at least in lay terms, the exchanges' potential to improve the accuracy of market prices. See Christie, 198 U .S. at 249 ("[T ] he quotations of prices from the market are of the utmost importance to the business world, and not least to the farmers...."); see also infra Part II.B (discussing the information arbitrage model).

75. See Christie, 198 U.S. at 249 ("Purchases made with the understanding that the contract will be settled by paying the difference between the contract and the market price at a certain time stand on different ground from purchases made merely with the expectation that they will be satisfied by set-off.") (citation omitted). See generally Patterson, supra note 51, at 863-84 (describing judicial tolerance for futures trading on organized exchanges).

76. See infra notes $277-78$ and accompanying text (arguing that the basic policy problem presented by speculation is filtering out welfare-reducing transactions from more beneficial forms of trading). 


\section{B. Codifying the Common L aw: A ntibucketshop Statutes and the Commodity Exchange A ct}

M odern legislation has largely replicated, and in important ways strengthened, the common law rule against difference contracts. Codification of the rule first began in the late nineteenth and early twentieth centuries, when a large number of state legislatures passed "antibucketshop" laws declaring contracts for the sale of goods illegal unless settled by delivery. ${ }^{77}$ L ike the common law, many of these statutes contained exclusions for organized futures trading ${ }^{78}$ and for indemnity agreements where one of the parties could prove a hedging purpose. $^{79} \mathrm{U}$ nlike the common law, many went beyond merely declaring difference contracts to be unenforceable by providing for criminal sanctions. ${ }^{80}$

A ntibucketshop laws remain on the books in many states. ${ }^{81}$ Their influence has waned, however, as the federal government has extended its own authority in the area. ${ }^{82}$ Congress first entered the field in 1921 with the Future Trading A ct, reenacted in 1936 as the Commodity Exchange A ct (CEA) ${ }^{83}$ The original CEA applied only to fu-

77. "Bucket shop" was a derogatory term applied to businesses that offered opportunities to wager on prices without actually delivering the stock or commodity in question. See Gatewood v. N orth Carolina, 203 U .S. 531, 536 (1906). In the typical bucket shop, a customer would bet on future prices with the bucket shop acting as bookie and matching customer bets against each other while assuming risks for any net position. See Stein, supra note 69 , at 477 . See generally N ote, L egislation E ffecting Commodity and Stock Exchanges, 45 H A R V. L. R E V. 912 (1932) (discussing antibucketshop laws).

78. See Dickson v. U hlmann Grain Co., 288 U.S. 188, 197 n.3 (1933) (listing state antibucketshop statutes that exempted exchange-traded futures); Note, supra note 77, at 920 n.35 (same).

79. See N ote, supra note 77 , at 919 n.32 (listing statutes with hedging exceptions).

80. See id. at 917 n.26 (listing statutes that criminalized bucket shops).

81. See, e.g., A LA. COde §§ 8-1-120 to 8-1-131 (1993); A RIZ. Rev. StA T. A NN. §§ 44-1651 to 44-1660 (West 1994); N.Y. G EN. B U S. LA W $\S \S 351$ to 351-e (M CK inney 1988).

82. Whether and to what extent the Commodity Exchange A ct preempts state antibucketshop laws is hotly debated. Compare Barry W. Taylor, The Commodity Exchange Act and O ther Bucket Shop L aws: The Future of Commodity Swaps Without Preemption, in THE SWA P MARKET IN 1990, at 501-47 (PLI Corporate Law and Practice Course Handbook Series No. 689,1990 ) (arguing that off-exchange "swaps" agreements might be subject to state antibucketshop and gambling laws), and J ulie M. A llen, K icking the B ucket Shop: The M odel State Commodity Code as the L atest Weapon in the State A dministrator's A nti-F raud A rsenal, 42 W A SH . \& LEE L. REV. 889, 891 (1985) (arguing that the CEA authorizes states to enact newly-drafted model code provisions regulating off-exchange futures and options), with $\mathrm{K}$ evin $\mathrm{T}$. V an Wart, Preemption and the Commodity Exchange Act, 58 CHI.-KENT L. REV. 657, 657-722 (1982) (arguing that the CEA preempts application of state laws to off-exchange derivatives trading).

83. The Future Trading A ct of 1921 (FTA ), Pub. L. N 0. 67-66, 42 Stat. 187, applied a pro- 
tures and options trading in cotton, grain, and a limited group of other agricultural commodities. ${ }^{84}$ In 1974, however, Congress significantly expanded the federal sphere of influence by extending the CEA to "all other goods and articles," including all "services, rights, and interests," ${ }^{85}$ and creating a five-member Commodity Futures Trading Commission (CFTC) charged with enforcing the statute. ${ }^{86} \mathrm{As}$ a result, federal regulators now play a leading role in curbing speculative trading.

To understand this point, it is essential to recognize that one of Congress's primary goals in enacting the CEA was to curb speculation in those goods and services that fall within the CEA's purview. A s originally enacted, section 5 of the CEA provided that "[e]xcessive speculation in any commodity under contracts of sale... for future delivery . . . is an undue and unnecessary burden on interstate commerce . . . . . ${ }^{87}$ Thus the centerpiece of the CEA is an "exchange trading requirement" that reincarnates, in a modified statutory form, the common law rule requiring contracts of sale for future delivery to be settled by actual delivery.

The CEA resembles the common law because it prohibits all contracts of sale for future delivery that are not made on, and subject to the rules of, an organized exchange. ${ }^{88}$ This prohibition does not apply, however, to contracts that are intended to be settled by delivering the underlying good or service. ${ }^{89}$ The net result is that trading in futures and options that are not intended to be settled by delivery is

hibitive tax to futures trades off organized exchanges. See id., 42 Stat. at 187. The Supreme Court subsequently held the FTA to be an unconstitutional exercise of the taxing power. See Hill v. Wallace, 259 U.S. 44, 63-72 (1922). The statute was subsequently reintroduced and passed under the Commerce Clause as the Grain Futures A ct (G FA) of 1922, Pub. L. N o. 67331, 42 Stat. 998. The GFA was significantly amended and renamed the Commodity Exchange A ct in 1936. See S. REP. N o. 93-1131, at 12-15 (1974), reprinted in 1974 U .S.C.C.A.N. 5843, 5852-56 (discussing the CEA 's history).

84. See S. REP. N o. 93-1131, at 14 (1974), reprinted in 1974 U .S.C.C.A .N. 5843, 5855

85. The Commodity Futures Trading Commission A ct of 1974, Pub. L. No. 93-463, § 201(b), 88 Stat. 1389, 1395 (codified as amended at 7 U.S.C. $\S 2$ (1994)) (defining the term "commodity" and providing for CFTC jurisdiction over all options and futures trading in commodities); see also Stein, supra note 69 , at $485-86$ (discussing the meaning of "commodity" under the CEA).

86. See The Commodity Futures Trading Commission A ct of 1974, Pub. L. No. 93-463, § 101(a) (3), 88 Stat. 1389, 1389-91 (codified as amended at 7 U .S.C. § 4a (1994)).

87. Commodity Exchange A ct, Pub. L. N o. 74-675, § 5, 49 Stat. 1491, 1492 (1936).

88. See 7 U.S.C. § 6(a)(1) (1994); see also Stein, supra note 69 , at $479-82$ (describing the CEA 's exchange trading requirement).

89. See 7 U .S.C. § 2 (1994); see also Stein, supra note 69, at 486-92 (discussing exemption for contracts intended to be settled by delivery). 
legally permissible only within the safe harbor of a regulated exchange. O ff-exchange "difference contracts" are not just unenforceable, but illegal under federal law. ${ }^{90}$

The CE A 's exchange trading requirement- sometimes dubbed a "ban on off-exchange futures" - thus plays a critical role in curbing speculative activity in the $U$ nited States economy. W hile an extensive list of contracts are approved for trading on the designated futures exchanges, for each commodity for which a contract is listed there are tens of thousands of goods and services not listed. ${ }^{91}$ W ould-be speculators hoping to take a position in the markets for miniskirts, mittens, Monets, mandarin oranges, management consultants, or Montana real estate will find that neither these nor most other goods and services have contracts listed for trading on a designated exchange. To speculate in these markets one must resign oneself to spot trading, with all its expense and inconvenience.

Indeed, the CEA in many respects keeps speculators on an even shorter leash than the common law did. Like many antibucketshop statutes, the CEA goes beyond the common law rule of civil unenforceability to provide for criminal penalties for off-exchange trading in contracts not settled by delivery. ${ }^{92}$ (The significance of this sanction is discussed further in Section IV.E.) Equally important, the CEA empowers the CFTC to act as a gatekeeper to the exchanges and to decide which contracts will be accepted for trading. A ny exchange seeking to offer a new type of future or option for trading accordingly must first demonstrate to the CFTC that the contract is not "contrary to the public interest" ${ }^{93}$ the CFTC has interpreted this dictate to require a showing that the contract serves some economic purpose beyond mere speculation. ${ }^{94}$ Within the sanctuary of the exchanges, the CFTC imposes other restrictions to deter speculative transactions. For example, the CFTC can seek to discourage speculative trading by imposing "position limits" that restrict the size of the position an in-

90. See, e.g., 7 U .S.C. § 13 (1994) (establishing criminal penalties for off-exchange trading in contracts not settled by delivery); CFTC v. Noble M etals Int'I, Inc., 67 F.3d 766, 772 (9th Cir. 1995) (holding "Forward D elivery Program contracts" to be illegal off-exchange futures where traders' customers did not expect to take actual delivery).

91. See Futures INDUSTRY A SSOCIATION, Volume OF FUtURES \& OPTIONS TRADING ON U .S. FUTURES EXCHANGES 6-8 (1992) (showing that in 1992, only 52 types of commodities saw futures trading volume in excess of 100,000 contracts on the $U$ nited States exchanges).

92. See 7 U.S.C. $\S 13$ (1994).

93. Id. § 7.

94. See 17 C.F.R. pt. 5, A pp. A (1998) (describing the economic purpose requirement); Stein, supra note 69 , at 482 (same). 
dividual trader can take in any particular contract, as well as "trading limits" that restrict the size of particular transactions. ${ }^{95}$

The net result is that federal legislation largely replicates, and in many respects strengthens, the common law's restrictions on speculation through difference agreements. A Ithough modern observers often overlook the CEA's antispeculation function, federal commodities law plays a fundamental role in channeling our nation's entrepreneurial energy away from speculative trading. Part IV returns to consider in greater detail the implications of this role for the CFTC's claim of jurisdiction over the market for financial derivatives.

\section{A ntispeculation Rules in Insurance $L$ aw: The D octrines of Indemnity and Insurable Interest}

The common law rule against difference contracts and the CEA both deter speculation in a similar fashion: by requiring speculators outside a regulated futures exchange to incur the costs associated with spot market delivery. This strategy, it turns out, is mirrored in insurance law. ${ }^{96}$ T wo doctrines that lie at the heart of insurance-the requirement of insurable interest and the indemnity principle-have both evolved, in part, to prevent speculators from using insurance for speculation.

95. See 7 U S.C. $§ 6 a(a)$ (1994) (directing the CFTC to impose limits on the size of traders' positions and transactions for the purpose of preventing "excessive speculation"). These limits are not applied to traders who can prove that their transactions hedge against a preexisting business risk. See id. § $6 a$ (c).

A number of other rules also discourage speculation in futures. For example, a customer who opens a futures trading account must sign a disclosure statement acknowledging that she understands the risks involved; she must also characterize the account either as a "trade" (or "hedge") account or a "speculative" account. The latter are scrutinized more carefully. See DARRELL DUfFIE, FUtURES MARKETS 67-70 (1989). Moreover, because exchange-traded futures and option contracts must include standardized terms regarding such matters as delivery date, contract size, and so forth, they are of limited value to many would-be speculators. For example, a trader who thinks wheat prices will rise 12 months hence cannot speculate through futures or options that expire in six months. See MEHRAJ MATTOO, StRUCTURED DERIVATIVES 13-14 (1997) ("[A ]Il futures contracts and exchange traded options have fixed attributes in terms of delivery dates, contract size, strike rates and so on. Such derivatives cannot, therefore, be tailored to specific hedging or investment requirements.").

96. A $n$ insurance policy is essentially an "option" in which the buyer pays a fixed fee for the right to profit if certain events occur. Thus the requirement that off-exchange contracts of sale be settled by delivery would be seriously undermined if speculators could use insurance to accomplish similar results. Consider the example of a speculator precluded from betting on local real estate prices through difference agreements who instead purchased a policy "insuring" nearby homes against a decline in market value. If the policy were enforceable, the speculator would reap a profit if prices fell without ever buying or selling a single property. 
There are several different tests for determining whether a policyholder has an "insurable interest." ${ }^{97}$ A a general rule, however, courts refuse to enforce an insurance policy unless the policyholder can demonstrate that she would suffer some significant economic detriment if the insured property is destroyed. ${ }^{98}$ Thus, the owner of an automobile has an insurable interest in her car, and her bank also may be able to purchase a policy if it financed the purchase and holds a collateral interest in the vehicle. Neither the owner nor the bank, however, can purchase a policy on some third party's vehicle.

Even for policyholders who hold insurable interests, recovery will be limited by a second antispeculation rule: the indemnity principle. Under the indemnity rules, a policyholder cannot recover any amount exceeding the economic value of her interest in the insured property. ${ }^{99}$ A $n$ automobile owner whose car is destroyed can recover the fair market value of the vehicle, but can not recover three times that amount even if she has purchased and paid for three policies. Similarly, her bank can recover only the amount of its unpaid loan.

The doctrines of indemnity and insurable interest arose in the earliest days of insurance law ${ }^{100}$ and persist, often in statutory form, to this day ${ }^{101}$ B oth reflect an axiom of insurance so fundamental that it goes to very meaning of the word: insurance policies are to compensate for losses suffered-not to generate profits. ${ }^{102}$ Two evils are

97. See generally Kenneth S. A braham, Insurance LaW and REgulation: Cases A ND M A TERIALS 195-200 (2d ed. 1995) [hereinafter A BRAHA M, InSURA NCE LAW]; Samuel A. R ea, J r., The E conomics of Insurance L aw, 13 INT'L REV. L . \& E CON. 145, 146-51 (1993); William T. Vukowich, Insurable Interest: When It M ust Exist in Property and L ife Insurance, 7 WILLA METTE L.J . 1, 1-42 (1971). The discussion below focuses on the rules of property insurance. Somewhat different doctrines apply in the case of life insurance, reflecting policy concerns outside the moral hazard and speculation issues addressed here.

98. See A BRAHAM , INSURA NCE LA W, supra note 97, at 199.

99. See id.; R ea, supra note 97, at 151-53. A limited exception exists in some states for "value" policies that specify the value of the property insured. See generally A BRAHAM, INSURA NCE LA W, supra note 97, at 263-64 (describing value policies).

100. See 1 James Oldham, The Mansfield Manuscripts and the Growth of ENGLISH LAW IN THE EIGHTEENTH CENTURY 469 (1992) (identifying the insurable interest doctrine in the earliest records of E nglish law).

101. See, e.g., A LA SKA STA T. § 21.42 .030 (M ichie 1998) (declaring that a policy without insurable interest is void; indemnity is limited to amount of insurable interest); A RIZ. REV. STAT. $\S 20-1105$ (1990) (same); DEL. CODE A NN. tit. 18, § 2706 (1989) (same); see also A BRAHAM, INSURANCE LAW, supra note 97, at 195-200 (discussing indemnity and insurable interest in the modern context).

102. See, e.g., R yan v. R oyal Ins. Co. of A m., 916 F.2d 731, 739 (1st Cir. 1990) (emphasizing that "the legitimate object of insurance is to provide reimbursement for loss-and nothing more"); see also A BRAHAM, INSURANCE LAW, supra note 97, at 199 (stressing that "the pur- 
thought to flow from using insurance policies for gain. The first is "moral hazard," a picturesque phrase referring to the fear that insurance might tempt policyholders into not protecting adequately against losses, or even destroying insured property for profit. ${ }^{103}$ The second fundamental concern underlying the indemnity and insurable interest requirements, however, is the fear that speculators otherwise would use insurance policies to wager on the future. ${ }^{104}$

B oth early and modern insurance cases frequently cite the antispeculation function of the indemnity and insurable interest rules, ${ }^{105}$ as does academic commentary dating well into the mid-twentieth century. ${ }^{106}$ M ore recently, however, scholars have shown a curious reluctance to credit the traditional antispeculation rationale, instead emphasizing moral hazard as the rules' underlying foundation. ${ }^{107}$ The very structure of the indemnity and insurable interest rules nevertheless reveals that they are at least as much concerned with discouraging speculation as they are with avoiding moral hazard. In some

pose of insurance is to protect the insured against suffering a loss, not to create the opportunity for gain").

103. See Vukowich, supra note 97, at 8-9 (describing insurable interest as a means of discouraging insureds from destroying lives and property); KENNETH S. ABRAHAM, DISTRIBUTING RISK: INSURANCE, LEGAL THEORY, AND PUBLIC POLICY 137 (1986) [hereinafter A BRAHAM, DISTRIBUTING RISK] (describing the indemnity rule as a guard against moral hazard).

104. See ABRAHAM, DISTRIBUTING RISK, supra note 103, at 137 (noting that the antiwagering rationale is the oldest justification for indemnity rules); V ukowich, supra note 97 , at 6-8 (identifying the antiwagering policy which underlies insurable interest).

105. See, e.g., Warnock v. Davis, 104 U .S. 775, 779 (1881) (holding that a policy held by a party without an insurable interest is unenforceable as "a wager policy, or a mere speculative contract"); B rockway v. M utual Benefit Life Ins. Co., 9 F. 249, 254 (W.D. Pa. 1881) (stating that policies purchased by individuals who lack insurable interest are "speculative insurance," and that the law does not sanction insurance "obtained for the purpose of speculation upon ... hazard" ); H elmetag's A dm'x v. M iller, 76 A la. 183, 186 (1884) (stating that “'wager policies' . . . are entitled to no higher dignity, in the eye of the law, than gambling speculations"); Crossman v. A merican Ins. Co. of N ewark, 164 N.W. 428, 429 (M ich. 1917) (finding that "[p]olicies of insurance founded upon mere hope and expectation and without some interest in the property, or the life insured, are objectional as a species of gambling"). For an example of a modern case, see J ackson N at'I Life Ins. Co. v. R ececoni, 827 P.2d 118, 130 (N.M. 1992) (noting that a lack of insurable interest "encourag[es] speculation").

106. See, e.g., Vukowich, supra note 97 , at 8-9 (discussing antiwagering policy).

107. See, e.g., POSNER, supra note 23 , at 107-08 (discounting the antiwagering argument and favoring moral hazard as the best explanation for indemnity and insurable interest rules); R ea, supra note 97, at 146-47, 151 (noting, but rejecting, the antiwagering explanation for the indemnity and insurable interest rules); see also A BRA H A M, I NSU RA NCE L A W, supra note 97, at 199 (noting that while the indemnity principle originated in the desire to prevent use of policies for speculation, "[t]he predominant justification now given for the requirement is that it combats moral hazard"). 
situations, for example, the requirement of insurable interest actually magnifies moral hazard problems. Consider the case of an insurance company that sells policies against damage from earthquakes or hurricanes. No policyholder is likely to be able to alter the chances of such a natural disaster occurring. A property owner can, however, take steps to limit any resulting damage through such preventative measures as reinforcing brickwork or storing valuables securely. If moral hazard was insurance law's principal concern, it would make more sense to allow insurance companies to sell earthquake and hurricane policies to third parties than to property owners. $Y$ et in the interest of discouraging speculation, the rules of insurable interest dictate exactly the opposite result.

A nother aspect of the indemnity and insurable interest rules that highlights their antispeculation origins is the fact that neither rule is waivable. ${ }^{108}$ Suppose a homeowner wants to violate the indemnity principle by taking out a policy that would pay three times her home's value in the event of its destruction. The insurance company could insist on a variety of terms (such as exclusions for arson) to protect itself against moral hazard. Moreover, to the extent moral hazard could not be eliminated entirely, the company could charge a higher premium. If no third parties are harmed, why not let the company sell the policy? ${ }^{109}$

A $s$ in the case of the rule against difference agreements, the doctrines of indemnity and insurable interest are curiously unyielding legal barriers to contract-even contracts entered by legally competent and mutually consenting parties. This inflexibility seems unjustified if moral hazard is the law's primary concern. Nonwaivability makes sense, however, if the insurable interest and indemnity rules are intended to protect society from the detrimental effects of speculation, as well as to protect insurance companies from their policyholders' misbehavior.

108. See, e.g., CAL. INS. CODE § 287 (1995) (stating that "[e]very stipulation in a policy of insurance for the payment of loss whether the person has or has not any interest . . . is void"); Ben Kennedy \& A ssocs. v. St. Paul Ins. Co., 40 F.3d 318, 319-20 (10th Cir. 1994) (refusing to enforce an agreement where both parties to a contract intended the policyholder to recover upon the happening of a contingent event without suffering actual loss); B rown v. J.C. Penney Cas. Co., 649 F. Supp. 22, 23 (E.D. M o. 1986) (observing that the requirement of an insurable interest is not waivable).

109. See Brockway, $9 \mathrm{~F}$. at 254 (positing that an insurable interest is required "not in the interests of insurance companies," but out of concern for "good morals and sound public policy"); see also Rea, supra note 97 , at 155-58 (discussing the indemnity and insurable interest rules as a response to concern for third parties). 


\section{The Securities Exchange A ct of 1934}

The rule against difference contracts, the CEA's ban on offexchange futures, and the insurance requirements of indemnity and insurable interest all force individuals who wish to wager on market prices to incur the transportation, carrying, and liquidity costs associated with doing business in the spot market. This makes speculative trading in most goods and services far more difficult and expensive. However, there is one spot market where transportation, carrying, and liquidity costs are inherently negligible: the market for corporate securities.

Corporate stocks and bonds are cheap to transport and almost costless to store. B ecause lenders readily accept them as collateral, buyers often can borrow the money needed to buy them, avoiding much sacrifice of liquidity. A s a result, the spot market for corporate securities offers a safe haven for speculators driven from other spot markets by high transaction costs. It is far easier to bet on petroleum prices by buying stock in Exxon than by hoarding fuel oil.

Not surprisingly, securities markets have long been associated with speculation. This association, moreover, has long troubled lawmakers. A Ithough movements to curb stock market speculation date back at least to the beginning of the twentieth century, ${ }^{110}$ it was not until the market crash of 1929 and the ensuing $G$ reat D epression that Congress decided to take action. The result was the Securities Exchange A ct of 1934 (SE A ). ${ }^{111}$

The SEA is not usually thought of as an antispeculation law. Nevertheless, curbing stock speculation was one of Congress's primary goals in passing that statute. ${ }^{112} \mathrm{R}$ ampant speculation was believed to be a root cause of both the 1929 market crash and the hard

110. See Steve Thel, The O riginal Conception of Section 10(b) of the Securities Exchange A ct, 42 StA N. L. R E V. 385, 394-407 (1990). For example, in 1908 President Theodore R oosevelt urged Congress to adopt measures to prevent "at least the grosser forms of gambling in securities," which he viewed as "pernicious to the body politic." Id. at 396 (quoting 42 CONG. REC. 1347, 1349 (1908)). Similarly, in 1912 a report by the House Committee on Banking and Currency found that speculative trading dominated the business of the stock exchange and that "[s]uch excessive and indiscriminate speculation ... is not only hurtful in the way that all public gambling is hurtful, but in addition it withdraws from productive industry vast quantities of capital." I d. at 403 (quoting H.R. REP. N o. 62-1593, at 45 (1913)).

111. Pub. L. N o. 73-291, 48 Stat. 881 (codified as amended at 15 U .S.C. §§ 78a-78II (1994)).

112. See Thel, supra note 110, at 395-424 (concluding that discouraging excessive speculation was a driving motive behind the passage of the $1934 \mathrm{Act}$ ). 
times that followed. ${ }^{113}$ Section 2 of the SEA accordingly describes the need for regulation as follows:

[T] ]ransactions in securities as commonly conducted upon securities exchanges and over-the-counter markets are affected with a national public interest ..... F requently the prices of securities on such exchanges and markets are susceptible to ... . excessive speculation, resulting in sudden and unreasonable fluctuations in the prices of securities .... N ational emergencies ... are precipitated, intensified, and prolonged by ... sudden and unreasonable fluctuations of securities prices and by excessive speculation .... .114

Like judges in difference contract cases, the 1934 Congress associated speculation with specific economic harms. Thus the House Reports accompanying the SEA condemned stock speculation as a nonproductive activity that drained credit and other valuable resources away from "other more desirable uses of commerce and industry." ${ }^{115}$ A second familiar concern highlighted in the legislative history was the fear that speculation produced "wide fluctuations in the price of securities, which ultimately imperiled the holdings of bona fide investors of every type." 116

Dedicated to curbing stock speculation in principle, in practice Congress found it difficult to design policies that would rein in speculators without also discouraging "legitimate" stock transac-

113. See S. REP. No. 73-792, at 3 (1934) ("Excessive [stock] speculation has caused acute suffering and demoralization. ... [It has also] brought in its train social and economic evils which have affected the security and prosperity of the entire country."). President Franklin D. R oosevelt wrote Congress to urge that it regulate the securities market because "[t]he people of this country are, in overwhelming majority, fully aware of the fact that unregulated speculation in securities and in commodities was one of the most important contributing factors in the artificial and unwarranted 'boom' which had so much to do with the terrible conditions of the years following 1929." Letter from Franklin D. R oosevelt, President, to Sam R ayburn, Chairman, H ouse Interstate \& Foreign Commerce Committee (M ar. 26, 1934), quoted in H.R. REP. No. 73-1383, at 2 (1934).

114. 15 U.S.C. § 78b (1994).

115. H.R. REP. N O. 73-1383, at 8 (1934); see also S. REP. No. 73-792, at 3 (1934) (finding that stock speculation siphoned credit "from agriculture, commerce and industry"); STAFF OF the Board of Governors of the Federal Reserve System, A Review and Evaluation of Federal Margin Regulations 118 (1984) [hereinafter ReVIEW of FEDERAL MARGIN REGULATIONS] (describing one main objective of the 1934 A ct as preventing the diversion of credit from productive uses into stock speculation).

116. S. REP. No. 73-1455, at 11 (1934). The notion that speculation caused price bubbles seemed, of course, especially compelling to a legislature sitting five years after the 1929 market's spectacular rise and fall. 
tions. ${ }^{117}$ O ne strategy eventually adopted to attack speculative excess was to impose "margin requirements" limiting investors' ability to borrow to buy stocks. ${ }^{118}$ Thus section 7 of the SE A directs the Federal R eserve Board to limit stock traders' ability to borrow money from banks or brokers to fund their speculations. ${ }^{119} \mathrm{U}$ nder present rules, investors can borrow no more than $50 \%$ of the funds they use to purchase corporate equities. ${ }^{120}$

A second provision of the SEA designed to curb speculation places restrictions on "short selling" - that is, selling borrowed stock. ${ }^{121}$ The 1934 Congress believed that short selling encouraged speculation, ${ }^{122}$ and concern about "shorting" played a central role in the hearings surrounding the SE A's passage. ${ }^{123}$ Section 10(a) of the A ct directs the Securities and Exchange Commission (SEC) to issue rules that restrict short selling. ${ }^{124} O$ ne interesting result is $\mathrm{R}$ ule $10 \mathrm{a}-1$, also known as the "uptick rule," which bans short sales except after a stock's price has risen. ${ }^{125}$

117. See Thel, supra note 110, at 423 (noting the perceived difficulty of designing substantive rules that would distinguish undesirable speculative trading from legitimate activity); see also infra note 171 (distinguishing speculation from investment).

118. M argin trading was widely believed to have encouraged speculation in the 1929 market by allowing traders to take large positions with relatively small commitments of personal funds. See H.R. REP. No. 73-1455, at 9 (1934) (discussing the effects of the crash on margin traders).

119. See 15 U.S.C. $\S 78 \mathrm{~g}$ (1994) (directing the Federal R eserve to impose margin requirements).

120. R egulation $\mathrm{T}$ does not permit investors to borrow more than $50 \%$ of a stock purchase from a securities firm. See 12 C.F.R. § 220.18(a) (1998). O ther regulations limit the abilities of banks and other firms to lend to investors. See Review of FEderal MARGIN REGULATIONS, supra note 115 , at 47-50.

121. See 15 U .S.C. § 78j(a) (1994). See generally J onathan R. M acey et al., Restrictions on Short Sales: An A nalysis of the Uptick Rule and Its Role In View of the O ctober 1987 Stock M arket Crash, 74 COR NELL L. REv. 799 (1989) (describing short selling rules); D avid C. W orley, The Regulation of Short Sales: The Long and Short of It, 55 BRooK. L. REV. 1255 (1990) (same).

122. See Thel, supra note 110 , at 410,432 . Short selling is associated with speculation because a short seller can profit only if he can sell the borrowed stock at a higher price than he must pay when the time comes to repurchase it and return it to the lender. Short sales thus amount to bearish bets on stock declines.

123. See M acey et al., supra note 121 , at $801-02$ (stressing the importance Congress placed on the role of short selling in the market crash of 1929).

124. See 15 U.S.C. § 78j(a) (1994).

125. See Short Sales, 17 C.F.R. § 240.10a-1 (1998). A dopted by the SE C shortly after passage of the $1934 \mathrm{Act}$, the uptick rule prohibits short selling unless it occurs at a price higher than the last reported market price (an "uptick"), or at a market price which is higher than the last reported, different price. See M acey et al., supra note 121, at 803-04. The uptick rule's an- 
In practice, it is unclear how effective margin requirements and shorts sales restrictions are in discouraging stock speculation. M argin requirements ignore the fungibility of credit, $^{126}$ while the uptick rule allows short selling after even a brief price increase. ${ }^{127}$ Perhaps more importantly, stock speculators have recently been able to evade both restrictions by trading in derivatives whose values mimic those of the underlying stocks. ${ }^{128}$

W hether the SE A 's margin requirements and short sales restrictions are effective or not, however, they are compelling evidence that the 1934 Congress believed both that speculators are endemic in the spot market for securities, and that they work much mischief there. ${ }^{129}$ The rules also reveal a legislative determination to curb stock speculation through substantive restrictions where necessary. Indeed, they

tispeculation purpose is reflected in its exceptions. For example, it does not apply to a seller who "owns the security sold and intends to deliver such security as soon as is possible." 17 C.F.R. § 240.10a-1(e)(1) (1996). This exception appears to distinguish between an investor who wants to close out a position in the cash market as soon as possible and needs to borrow the security for settlement, and a speculator who simply wants to wager on a market downturn. See M acey et al., supra note 121, at 808-11 (discussing the exemptions from the uptick rule for certain hedging transactions).

0 ther rules also restrict short selling. See id. at 812 (noting that short selling is subject to more severe regulation than other forms of trading). Short sellers, for example, are subject to higher margin requirements. See id. Section $16(\mathrm{~b})$ of the $1934 \mathrm{~A}$ ct also forbids corporate officers, directors, and large shareholders from selling short. See 15 U .S.C. § 78p (1994). U ntil recently, many institutional investors were also deterred from short selling by the belief that they would suffer severe tax penalties on any profits earned by short selling. See V ineeta A nand, Pension Funds M ay Sell Short: IRS M ove is Expected to B oost U se of M arket-N eutral Strategies, PENSION \& INVESTMENT, Jan. 9, 1995, at 1.

126. For example, speculators banned from borrowing more than $50 \%$ of their stock purchases from their brokers may be able to easily fund their acquisitions by taking out home equity loans or increasing credit card debt.

127. This curious asymmetry reflects historical context. Short selling was thought to have exacerbated the 1929 crash by creating a ready vehicle for fearful speculators to bet on their pessimistic predictions. See M acey et al., supra note 121, at 801 (discussing how the 1929 crash led to concerns over short selling). In adopting Rule 10a-1, the SE C accordingly focused only on preventing "demoralizing" speculation. See SEC, REPORT OF THE SPECIAL STUdY OF SECURITIES MARKETS, H.R. DoC. No. 88-95, pt. 2, at 251 (1963) (noting that short sales restrictions were intended to discourage only "demoralizing" speculation). Thus, the uptick rule seeks to prevent speculative bubbles from bursting, rather than to hinder their formation in the first place.

128. See W orley, supra note 121 , at 1268-69 (describing how stock derivatives allow traders to evade short sales restrictions).

129. See Thel, supra note 110, at 385 (arguing that Section 10(b) of the SE A was primarily intended not to protect investors from fraud, but "to empower the Securities and Exchange Commission (SE C) to regulate any practice that might contribute to speculation in securities"); see also infra note 306 (describing how the SEA 's disclosure provisions may discourage speculation by encouraging subjective agreement). 
flatly prohibit certain transactions deemed too closely tied to speculation.

These observations highlight a curious phenomenon: many contemporary scholars and policymakers appear to have forgotten the SEA's antispeculation goals. Instead, conventional wisdom now views the SEA as first and foremost a disclosure statute. Thus the Supreme Court has opined that "the fundamental purpose of the 1934 A ct [is] 'to substitute a philosophy of full disclosure for the philosophy of caveat emptor,'" ${ }^{131}$ while academics have asserted that the dominating principle of federal securities regulation "is that anyone willing to disclose the right things can sell or buy whatever he wants at whatever price the market will sustain." ${ }^{132}$

This modern perception of the SE $A$ is in tension with the Act's language and its history. Section 2 of the SE A, in describing the A ct's purposes, refers twice to "excessive speculation" but does not even mention disclosure of information. ${ }^{133}$ Similarly, a recent historical study of the SEA concluded that "in 1934 there was a widespread consensus that excessive stock market speculation and the collapse of the stock market had brought down the economy [and] those who enacted the Exchange A ct were primarily concerned with preventing

130. These spot market restraints, it should be noted, are unique to securities. A n optimistic speculator who wants to "go long" by buying fine art or beachfront property is free to use his purchase as collateral for as large a loan as the bank is willing to give him, just as a pessimist is free to borrow such assets to sell short when prices are falling. Practical obstacles limit short selling in most spot markets outside the market for securities, however. See infra text accompanying notes 219-23.

131. Santa Fe Indus. v. G reen, 430 U .S. 462, 477 (1977) (quoting A ffiliated U te Citizens v. U nited States, 406 U .S. 128, 151 (1972)).

132. Frank H. Easterbrook \& D aniel R. Fischel, M andatory D isclosure and the Protection of Investors, 70 V A . L. R EV . 669, 670 (1984). The heterogeneous expectations model of speculation suggests that mandatory disclosure rules may in fact discourage stock speculation by providing investors with uniform information that encourages homogeneous expectations. See L ynn A . Stout, A re Stock M arkets Costly Casinos? D isagreement, $M$ arket $F$ ailure, and Securities Regulation, 81 V A . L. R EV . 611, 695-97 (1995) [hereinafter Stout, Casinos] (arguing that mandatory disclosure may reduce heterogeneous expectations). A s a rule, however, modern scholars describe the SEA's disclosure provisions not as one of many statutory means toward the end of reducing speculation, but as the SEA 's singular purpose. See E asterbrook \& Fischel, supra, at 670 . D isclosure in turn is usually defended as essential to the "accuracy enhancement" of stock prices. E dmund W. K itch, The Theory and Practice of Securities D isclosure, 61 B R o o K. L. REV . 763, 764-65 (1995). B ut see generally L ynn A. Stout, The Unimportance of B eing E fficient: An E conomic A nalysis of Stock Market Pricing and Securities Regulation, 87 MICH. L. REV. 613, 692-95 (1988) (arguing that accurate securities prices may not provide as much economic benefit as is commonly assumed).

133. 15 U .S.C. § 78b (1994). 
a recurrence." ${ }^{134}$ Concern for excessive stock speculation nevertheless seems to have largely disappeared from the agendas of modern securities scholars and policymakers. ${ }^{135}$

\section{$E$. Summary: The P revalence of $A$ ntispeculation $L$ aw}

"A ntispeculation law" generally is not taught as a subject in the modern legal curriculum. Perhaps it ought to be, for hostility towards speculators appears to be a fundamental characteristic of A merican law. The rule against difference contracts, the CEA, the doctrines of indemnity and insurable interest, and the SE A 's margin requirements and short sales restrictions each play important roles in deterring speculative trading. They are, however, only a few of the many legal doctrines that work to rein in speculators. A policy of discouraging speculative trafficking in legal claims lies at the heart of the doctrine of champerty, the common law prohibition against buying and selling lawsuits that survives in statutory form in most states. ${ }^{136}$ The Internal R evenue Code also deters speculation by limiting preferential capital gains treatment of income earned from the sale of assets to those held for some minimum period (under current law, one year). ${ }^{137}$ This discourages speculation in spot markets outside the CFTC's jurisdiction, including not only the spot market for corporate securitiesalready subject to the SE A 's margin requirements and short sales restrictions-but also spot markets for fine art, real estate, and other tangible assets. Although modern observers often attribute the holding period requirement to concerns over inflation, income averaging, and "lock in" effects, ${ }^{138}$ legislative history indicates that Con-

134. Thel, supra note 110 , at 409.

135. Instead, debate in the legal literature has focused primarily on the wisdom and necessity of mandatory disclosure rules. See, e.g., Symposium, Contemporary Problems in Securities Regulation, 70 V A . L. R EV . 545 (1984) (discussing modern securities regulation).

136. See, e.g., N.Y . JUD. LAW § 489 (M CK inney 1998); cf. A ri D obner, N ote, Litigation for Sale, 144 U. PA. L. REV. 1529, 1543-55 (1996) (discussing the history of and the policy behind champerty laws). A nother common law rule reflecting antispeculation bias is the "prudent person" standard applied to trustees, which has been interpreted to preclude speculation. See M ichael T. J ohnson, Note, Speculating on the E fficacy of "Speculation": A n A nalysis of the Prudent Person's Slipperiest Term of A rt In Light of M odern Portfolio Theory, 48 STA N. L. REV. 419, 419-20 (1996).

137. See I.R.C. $\S 1222$ (1998). This rule applies to income earned from the sale of "capital assets," generally defined as property not used in a taxpayer's trade or business. Id.

138. See, e.g., Joseph A. Pechman, Federal TAX Policy 116-22 (5th ed. 1987) (describing holding period requirement as responding to inflation, income averaging, and lock in effects). 
gress adopted the requirement to reward long-term "investment" while discouraging short-term "speculation." 139

Throughout most of the nineteenth and twentieth centuries, A merican judges and legislators appear to have followed a policy of actively and deliberately discouraging speculative transactions. R ecent years have seen a curious development, however. Lawmakers' longstanding belief that speculation is harmful seems to be eroding. A Ithough antispeculation rules remain a staple of A merican law, contemporary observers seem increasingly reluctant to subscribe to the notion that deterring speculation should be a goal of public policy. Thus academics routinely offer alternative justifications for such traditional antispeculation rules as the SEA (now described as a disclosure statute) or insurance law's indemnity principle (now explained as a response to moral hazard). ${ }^{140}$

What explains this modern skepticism towards antispeculation laws? The answer may lie in economic theory's growing influence on legal thinking. Judges and legislators traditionally condemned speculators as nonproductive parasites whose trading destabilizes market prices and often brings financial ruin to speculators themselves. Contemporary economic theory, however, describes speculators in far more flattering terms. Thus the next Part of this A rticle turns to prevailing economic theories of speculation and the modern notion that speculators serve the economic goal of allocative efficiency.

139. See, e.g., S. REP. N o. 77-1631, at 50 (1942) (noting that the holding period requirement would be a "deterrent to the speculator as contrasted with the legitimate investor"); STA FF OF the Joint COMm. on TAXation, 94th Cong., General Explanation of the Tax REFORM A CT OF 1976, at 426 (Comm. Print 1976) (same). The Committee staff explained that the holding period requirement favors gains from investment over speculative profits, because:

[A ] person who holds an asset for only a short period of time is primarily interested in obtaining quick gains from short-term market fluctuations, which is a distinctively speculative activity.... [W hile] the person who holds an asset for a long time probably is interested fundamentally in the income from his investment and in the longterm appreciation value.

Id.; see also infra note 171 and accompanying text (discussing the distinction between investment and speculation).

140. See supra text accompanying notes 105-09, 131-35. 


\section{Conventional E COnOmic Theories of Spe Cula tion: The RISK HEDGING AND INFORMATION ARBITRAGE MODELS}

A $n$ extensive economic literature discusses the phenomenon of speculation. ${ }^{141}$ The exact meaning of the term, however, has proven remarkably elusive. Theorists generally use the word "speculator" to refer to someone who purchases an asset with the intent of quickly reselling it, or sells an asset with the intent of quickly repurchasing it. ${ }^{142}$ This approach distinguishes speculators from those who trade in goods and services because they produce or consume them, and also may offer a rough means of differentiating short term "speculation" from long term "investment." ${ }^{143}$ Beyond this basic starting point, modern finance lacks a generally accepted definition. ${ }^{144}$

Speculation is a slippery concept, in part, because more than one motive can inspire short-term trading. In fact, the contemporary economic literature appears to incorporate two distinct explanations for speculative trading: risk hedging and information arbitrage.

\section{A. Risk H edging}

In economic parlance, "risk" refers to probabilistic variation in wealth: chances of gains, as well as of losses. ${ }^{145} \mathrm{E}$ conomic theory holds

141. See, e.g., J ean-Pierre D anthine, Information, Futures Prices, and Stabilizing Speculation, 17 J. E CON. THEORY 79 (1978); Sanford G rossman \& J oseph Stiglitz, On The Impossibility of Informationally E fficient M arkets, A M. E CON. REV., J une 1980, at 393; O liver D. H art \& D avid M. K reps, Price D estabilizing Speculation, 94 J. POL. E CoN. 927 (1986); A Ibert S. K yle, Informed Speculation with Imperfect Competition, 56 REV. ECON. STUD. 317 (1989); John Leach, Rational Speculation, 99 J. POL. E CON. 131 (1991).

142. See Martin S. Fridson, Exactly What Do Y ou Mean by Speculation?, J. Portfolio MGMT., Fall 1993, at 29.

143. See infra note 171 and accompanying text (discussing speculation and investment).

144. See Fridson, supra note 142 , at $29-30$ (noting the lack of a universally accepted definition of the term "speculation"); H art \& K reps, supra note 141, at 928 (same); J ohnson, supra note 136, at 420 (same). This lack of precision creates difficulties when legal rules treat "speculative" transactions differently from nonspeculative ones. See, e.g., 26 C.F.R . § 1.1221-2 (1998) (attaching different tax consequences to speculative and hedging transactions); see also GA $O$ REPORT, supra note 11, at 102 (lamenting the lack of a "clear distinction between dealing activities, speculative activities, and hedging and other risk-management activities" using derivatives); J ohnson, supra note 136, at 420 (noting that the lack of clear understanding of what is speculation "often creates paralyzing uncertainty for trustees"). Part III suggests that finding a generally accepted definition of "speculation" has proven to be something of an enduring puzzle for economic theory because one of the pieces- the heterogeneous expectations approach-has been missing.

145. Consider the choice between either receiving a quarter with certainty, or tossing the coin "double or nothing." B ecause a $50 \%$ chance of receiving 50 cents has an expected value of 
that people generally dislike risk, and are willing to pay to avoid it (hence the insurance industry). ${ }^{146} \mathrm{The}$ flip side of risk aversion is that individuals with greater tolerance for risk can, like insurance companies, reap profits by accepting risks others pay to avoid. A ccording to the risk hedging model of speculation, speculators are just such relatively risk-neutral traders. ${ }^{147}$

Consider the classic example of the wheat farmer whose crop will soon be ready for harvest. If the farmer is risk averse-more concerned about the chance that prices will fall than the chance that they will rise-she might prefer to sell her crop now at a slight discount, and deliver it thirty days hence. Conversely, a more riskneutral wheat speculator might purchase such a contract because the price discount creates a "risk premium" that compensates him for accepting the chance of future price changes. ${ }^{148}$

A s this scenario suggests, the risk hedging model implies that speculative trades generally involve "hedgers" on one side of the transaction, and "speculators" on the other ${ }^{199} \mathrm{~A}$ second important implication is that both parties regard themselves as better off after trading than they were before. R isk-averse hedgers are happy to pay to avoid the price variation inherent in holding assets, while more risk-neutral speculators are happy to be paid a premium to assume that risk. ${ }^{150}$ Thus the risk hedging model is consistent with the

25 cents, both options offer the same probable return. The second option is riskier than the first, however.

146. See POSNER, supra note 23 , at $12-13$ (contending that "most people are risk averse most of the time").

147. See id. at 54-55 (describing risk hedging). This time-honored theory is often associated with J ohn M aynard K eynes and J ohn H icks, among others. See J ack H irshleifer, The Theory of Speculation under A Iternative Regimes of M arkets, 32 J. FIN. 975, $975 \&$ n.1 (1977) [hereinafter Hirshleifer, Theory of Speculation] (citing JOHN R. HICKS, VALUE AND CAPITAL 137-39 (2d ed. 1946); 2 J OHN M. KEYNES, A TREATISE ON MONEY, ch. 29 (1930)).

148. This risk premium implies that although risk-bearing speculators may lose money on some trades, over time the average speculator should be able to reap risky, but certain, profits. See infra text accompanying notes 167-71 (defining risk and uncertainty).

149. A Iternatively, a risk hedging trade may involve a hedger on both sides, as when a wheat farmer sells futures to a cereal manufacturer that uses wheat as a productive input. The risk hedging model does not explain, however, trades between two speculators. See infra text accompanying note 171 (discussing how the heterogeneous expectations approach can explain speculator-with-speculator trading).

150. A third, similarly symbiotic explanation of speculation occasionally found in the finance literature is the liquidity dealing approach. Because people value and are willing to pay for liquidity, a trader willing to maintain inventory can extract profits by offering to buy at a slightly lower price than he offers to sell, thus creating a "bid-ask spread" that compensates him for the risks and costs of keeping inventory. A classic example might be the used car dealer, who offers liquidity (for a price) to those too impatient to buy and sell through the classified 
"invisible hand" view of markets in which voluntary exchange is presumed to reallocate resources in a fashion that benefits both the trading parties and society as a whole.

\section{B. Information A rbitrage}

In addition to the risk hedging theory, the economic literature frequently incorporates a second model of speculative trading: the information arbitrage model. ${ }^{151}$ The information arbitrage approach describes speculators as traders whose research helps them to predict future changes in prices. A rmed with superior knowledge, they then trade on favorable terms with less-informed buyers and sellers who are trading for other reasons. Thus a wheat speculator who collects data on the regional harvest might discover a brewing shortage that presages a price rise and then profit by buying wheat from less well informed farmers.

Like the risk hedging approach, the information arbitrage model implies that speculators need nonspeculators (for example, wheat farmers and consumers) with whom to trade. Thus the information arbitrage model does not address the scenario where an optimistic speculator who believes he has superior information about future prices buys from a pessimistic speculator who believes she has superior information about future prices. (Such speculator-withspeculator trading is discussed in greater detail in Part III.) The information arbitrage model also resembles the risk hedging model in predicting that information arbitrage speculators should, on average, profit from their trades. Indeed, in theory superior information about future prices should allow information arbitrage speculators to reap risky but certai ${ }^{152}$ profits: for example, a trader who accurately predicts a probable rise in the price of wheat can lock in profits by buying wheat while also buying a "put" option that insures against the unlikely event of a price decline by giving the speculator the option

ads. See, e.g., H art \& K reps, supra note 141, at 928 (developing a model of consumers and speculators where "speculation is synonymous with storage"). Like the risk hedging model, the liquidity dealing model of speculation implies that speculators trade with nonspeculators, and that speculators generally make money at their counterparties' expense. Like the risk hedging model, the liquidity dealing approach also predicts that both sides nevertheless benefit from trading.

151. This approach is often associated with a classic article by G rossman and Stiglitz, On the Impossibility of Informationally E fficient M arkets, supra note 141; see also POSNER, supra note 23 , at 54-55 (describing speculation on superior information); D anthine, supra note 141, at 84-85 (same); K yle, supra note 141, 341-42 (same).

152. See infra text accompanying notes 167-71 (distinguishing risk and uncertainty). 
to sell at today's prices. Thus trading on truly superior information is described herein as a form of "arbitrage," in which the trader arbitrages between time periods, rather than between markets.

The information arbitrage approach parts company with the risk hedging model, however, by suggesting that trading between speculators and nonspeculators may not necessarily benefit both parties. (O ne can see how uninformed farmers might prefer not to trade at a disadvantage against savvier speculators.) $Y$ et society still benefits from information arbitrageurs' trades. A rbitrageurs ferret out information that indicates whether prevailing prices are "too low" (a shortage is developing that will raise prices) or "too high" (a surplus will soon depress prices). By buying when prices are low and selling when prices are high, they tend to move prices in the "correct" direction. Thus, for example, if arbitrageurs buy wheat in times of a brewing shortage, prices rise and farmers respond by planting more wheat, helping to reduce the shortage. In economic parlance, information arbitrage contributes to "pricing" or "informational" efficiency, ${ }^{153}$ which in turn promotes allocative efficiency.

It is important to note that these pricing benefits can be exaggerated. Information arbitrageurs must invest time and money to acquire superior information about future prices, and these research costs are ultimately borne by their less-informed counterparties. Thus there is no guarantee that the private cost of arbitrageurs' information gathering will always be outweighed by its public benefit in terms of an improved allocation of society's scarce resources. ${ }^{154}$ The information arbitrage model nevertheless supports the claim that "speculation is efficient" by predicting that speculators help prices reflect supply and demand more accurately.

153. See supra note 132 (discussing informational efficiency in securities markets).

154. See Hirshleifer, Information and Invention, supra note 29, at 567-69. Consider the example of information that allows an arbitrageur to forecast with certainty that a particular company's assets will be destroyed within minutes by a huge meteorite. A ssume that no steps can be taken to prevent, or even alleviate, the loss. The ability to predict the meteorite has no social value, because acquiring the information does not permit society to allocate resources more efficiently. The prediction nevertheless has substantial private value to the arbitrageur who can extract wealth from uninformed traders by "shorting" the company's stock. See supra notes 121-28 and accompanying text (describing short selling). Thus the arbitrageur might invest substantial resources in meteorite prediction, even if such expenditures are wasteful from a social perspective. 


\section{Summary: N ormative Implications of Conventional Theories}

The risk hedging and information arbitrage models of speculation rely on diverging explanations of why someone might expect to profit from buying, and then quickly reselling, goods or services. B oth models imply, however, that speculative trading furthers efficiency, either by shifting risk between parties in a fashion that generates mutual gains (risk hedging), or by improving market prices' accuracy as barometers of future supply and demand (information arbitrage). Given this result, it should come as no surprise that economics scholars frequently rise to defend the honor of the speculator, ${ }^{155}$ or that economic theory is seen as generally supporting speculative trading. ${ }^{156}$

$Y$ et if theory blesses the speculator, why has the law historically condemned him? The unflattering perceptions of speculators described in Part I seem to conflict directly with the risk hedging and information arbitrage models. The idea that speculation is "nonproductive," for example, seems inconsistent with both theories, as both assert that speculation promotes efficiency. The belief that speculators "derange" prices flies in the face of the information arbitrage theory's claim that speculators improve price accuracy. A nd the notion that speculation increases the incidence of poverty, while crafted by judges untutored in the language of modern economics, can be interpreted as an assertion that speculation increases the level of risk found in the market-directly contradicting the risk hedging model's prediction that speculation effectively reduces risk by reallocating it to those who can bear it most easily. ${ }^{157}$

The result is a remarkable clash between modern economic thinking and the legal tradition of hostility towards speculators. ${ }^{158}$ This conflict has led many contemporary policymakers and scholars to become increasingly reluctant to support legal rules that deter

155. See, e.g., POSNER, supra note 23 , at 54 (arguing that speculators perform "a valuable economic function").

156. In the ongoing debate over derivatives, for example, champions of derivatives have relied strongly on the claim that derivatives trading reduces risk and improves the accuracy of market prices. See infra note 263 and accompanying text.

157. This idea also seems inconsistent with the risk hedging and information arbitrage models' prediction that speculators on average profit from trading. See supra text accompanying notes 148 (describing how risk-accepting speculators are paid a risk premium) and 152 (noting that information arbitrageurs should earn trading profits).

158. The apparent clash between economic theory and lawmakers' perceptions is not absolute. For example, the indemnity exception to the rule against difference contracts seems designed to protect transactions that provide insurance benefits of the sort described by the risk hedging model. See supra text accompanying notes 65-67 (discussing indemnity exception). 
speculative trading. The SEC, for example, has recently questioned the value of short sales restrictions on the grounds that economic theory predicts that speculation promotes efficiency. ${ }^{159}$ Similarly, the Federal R eserve has rejected the idea that margin limits are necessary to keep stock speculators from diverting credit from more productive uses as inconsistent with economic thinking. ${ }^{160} \mathrm{~A}$ nd in the ongoing battle over OTC derivatives, champions of derivatives have argued that trading should remain unregulated because it reduces risks and improves the accuracy of market prices. ${ }^{161}$

In short, contemporary scholars and policymakers seem increasingly inclined to view speculation as a beneficial, rather than harmful, activity. $Y$ et hostility towards speculators seems too deeply rooted in the A merican legal system to comfortably dismiss antispeculation laws as inefficient anachronisms. Indeed, the chasm between modern economic theory and lawmakers' traditional perceptions seems so great as to raise the question: are both discussing the same phenomenon?

159. See Self-R egulatory O rganizations, Exchange A ct R elease N o. 34-34277, 59 F ed. R eg. $34,885,34,891$ (1994) (stating that short sales regulations can "hinder efficient price discovery"); W orley, supra note 121, at 1255-56, 1268-71 (stating that "the Commission noted that short selling activities ... might actually be beneficial in that [they] . . facilitate[] a decline to a price that reflect[s] the market's perception of ... true value"); see also Sullivan \& L ong, Inc. v. Scattered Corp., 47 F.3d 857, 860, 862 (7th Cir. 1995) (defending short selling as providing an "economic service" by moving prices toward their "true value").

160. Instead, the Federal R eserve now justifies margin requirements as protection against "systemic risk." See Review of Federal MaRgin RegULATIONS, supra note 115, at 2-3, 1015. But see id. at 6 (acknowledging that "protection of brokers- or of the market mechanism more generally - was not a central focus of the writers of securities credit legislation a half century ago").

161. See H u, M isunderstood D erivatives, supra note 7, at 1466; 1513 (defending derivatives on efficiency grounds and arguing against regulation); Jerry W. Markham, "Confederate Bonds," "General Custer," and the Regulation of Derivative Financial Instruments, 25 SETON H A LL L. REV . 1, 72 (1994) [hereinafter M arkham, Confederate B onds] (same); J erry W. M arkham, Regulation of $\mathrm{H}$ ybrid Instruments Under the Commodity Exchange A ct: A Call for A Iternatives, 1990 Colum. Bus. L. REV. 1, 53 (1990) [hereinafter Markham, Hybrid Instruments] (same); Romano, supra note 7, at 5 (same); Stein, supra note 69, at 498 (same). Similarly, scholars have criticized other antispeculation doctrines on the theory that speculation is economically beneficial. See, e.g., POSNER, supra note 23, at 487-88 (attacking the SEA's short sales restrictions and margin requirements as reducing speculation's beneficial effects); D obner, supra note 136, at 1565, 1566 (arguing that the antispeculation policy underlying champerty rule conflicts with the "fact" that "speculation . . . is the cornerstone of our modern capitalist economy"); Stout, Casinos, supra note 132, at 699-700 (discussing recent administration proposals to impose a modest federal tax on trading in corporate equities and raising the possibility that such legislation may be motivated by a desire to curb behavior viewed as undesirable). 


\section{The HeTEROgEnEOUSEXPECTATIONSTHEORY OF SPECULATION}

The two conventional theoretical models of speculative trading surveyed in Part II explain speculation as a consequence of differences among traders: either differences in their attitudes towards risk (the risk hedging model), or differences in their willingness to invest in the information needed to predict future prices (the information arbitrage model). There is a third type of difference among traders, however, that may lie closer to the legal culture's traditional understanding of speculation-differences in traders' subjective expectations.

\section{A. The $\mathrm{H}$ eterogeneous $\mathrm{E}$ xpectations A pproach}

The heterogeneous expectations (HE) model of speculation begins with the assumption that individuals' predictions for future prices can differ markedly: where a bull believes that prices are sure to rise, a bear predicts a fall. D isagreement of this sort is a natural consequence of incomplete and heterogeneous information. ${ }^{162}$ The information arbitrage model incorporates the idea of heterogeneous information to some extent, by hypothesizing that speculators invest in predictive information that allows them to earn trading profits at the expense of less well informed counterparties, who are trading for consumption or other nonspeculative reasons. The information arbitrage model fails to account, however, for the possibility that two speculators who invest in different predictive information might reach different conclusions about the future. ${ }^{163}$

1. A $\mathrm{n}$ E xample of Trading B ased on H eterogeneous E xpectations. $R$ ecognizing that traders who rely on heterogeneous, incomplete subsets of information might make differing predictions for the future suggests an alternative theory of speculative trading that can perhaps be most easily understood by considering an archetypal example. Suppose that, after investigating the gold market, a risk-averse

162. Like other resources, information is often scarce and expensive. A s a result, even the most rational of individuals often acts on incomplete information. Moreover, different individuals may have ready access to, and rely on, different subsets of incomplete information.

163. A Iternatively, two traders who acquire the same information might reach different conclusions because they interpret the data differently in light of their own past experiences. This is much the same thing, as traders with differing experiences are effectively relying upon different subsets of information. 
speculator who has no interest in producing or consuming gold predicts that there is a $100 \%$ chance that today's gold price of $\$ 500$ per ounce will rise to $\$ 510$ tomorrow. A second, equally risk-averse speculator who also has researched the market disagrees, and predicts a $100 \%$ chance that prices will fall to $\$ 490$. The bull perceives an expected return of $\$ 10$ per ounce from buying, while the bear sees an expected return of $\$ 10$ per ounce from selling. Thus, the bull eagerly buys while the bear eagerly sells.

A s this example demonstrates, traders who share identical risk preferences and willingness to invest in information nevertheless may trade voluntarily in assets they neither produce nor consume if they make differing estimates of the probability distribution of future prices. In effect, HE speculation is a form of wagering where the gamblers bet on market prices, rather than on the outcome of a card game or sporting contest. A s M ark Twain once observed, differences of opinion make a horserace. ${ }^{164}$ The $\mathrm{HE}$ theory of speculative trading suggests that differences of opinion also can make a stock market or futures exchange.

Noneconomists are likely to find the idea of disagreement-based trading intuitively quite plausible. So has at least one prominent economist: over two decades ago, J ack $\mathrm{H}$ irshleifer published a series of papers offering a theory of speculative trading based on differential beliefs. ${ }^{165} \mathrm{~F}$ or reasons which are explored further below, however, $\mathrm{H}$ irshleifer's approach is rarely mentioned in contemporary discussions of speculation. ${ }^{166} \mathrm{M}$ oreover, $\mathrm{H}$ irshleifer himself did not discuss

164. See Samuel L. Clemons, Pudd'nhead Wilson and Those Extraordinary TWINS 92 (Sidney E. Berger ed., W.W. Norton \& Co. 1980) (1894) ("It were not best that we should all think alike; it is difference of opinion that makes horse-races.").

165. See J ack H irshleifer, R eply To Comments on "Speculation and E quilibrium: Information, Risk, and M arkets," 90 Q . J. E CoN. 689 (1976); J ack H irshleifer, Speculation and E quilibrium: Information, Risk, and Markets, 89 Q. J. EcoN. 519 (1975) [hereinafter H irshleifer, Speculation and E quilibrium]; $\mathrm{H}$ irshleifer, Theory of Speculation, supra note 147; see also J A CK HIRSHLEIFER, Two Models of Speculation and Information [hereinafter HIRSHLEIFER, Two Models], in TIME, U NCERTA INTY, A ND INFORMA TION 291-300 (1989) (responding to a critique of the idea of disagreement-based trading). H irshleifer attributes a similar approach to Professor Holbrook Working. See Hirshleifer, Speculation and Equilibrium, supra, at 519 (citing Working's argument that speculative hedging depends upon varying beliefs or knowledge regarding price prospects).

166. See J eremy C. Stein, Informational Externalities and Welfare-reducing Speculation, 95 J. POL. E CON. 1123, 1125 (1987) (noting that papers on speculation tend "to ignore the issue of heterogeneous information among market participants"). For examples of papers ignoring subjective disagreement, see $\mathrm{H}$ art \& $\mathrm{K}$ reps, supra note 141, at 928-29 (assuming that speculators have access to the same information and therefore draw identical inferences); L each, supra 
the normative implications of the model he proposed. $\mathrm{H}$ is work nevertheless suggests an alternative way of thinking about speculative markets that differs strikingly from the risk hedging and information arbitrage approaches.

2. Characteristics of HE Trading: Uncertainty, Speculator-withSpeculator Trading and Ex Post Speculator L osses. Three important characteristics of $\mathrm{HE}$ trading can help to develop the distinction between $\mathrm{HE}$ speculation on the one hand, and risk hedging and information arbitrage on the other. The first is uncertainty as a prerequisite to trade. A Ithough even sophisticated commentators often blur the distinction, "risk" and "uncertainty" are not synonyms. "R isk" describes circumstances where the future is unknown, but the probability distribution of possible futures is known. A coin toss, for example, is risky but not uncertain: although we do not know whether a tossed coin will come up heads or tails, we know-and can agree- that there is a $50 \%$ chance of either occurring. ${ }^{167}$ "U ncertainty," in contrast, describes circumstances where the probabilities of possible future outcomes are themselves imperfectly known. ${ }^{168}$ Thus the stock market is both risky and uncertain: we not only do not know if the market will rise or fall, we also do not know-and therefore can disagree on-the probability of either event. ${ }^{169}$

note 141, at 132 (modeling speculation based on the assumption that all agents place an identical value on a given asset).

167. See Mark J. Machina \& Michael Rothschild, Risk, in The New Palgrave: A DICTIONARY OF E CONOMICS 201, 201 (J ohn Eatwell et al. eds., 1987) [hereinafter THE NEW PALGRAVE] ("A situation is said to involve risk if the randomness facing an economic agent can be expressed in terms of specific numerical probabilities...."); see also Paul D avidson, Is Probability Theory Relevant for Uncertainty? A Post K eynesian Perspective, J. EcoN. PERSP., W inter 1991, at 129, 130-31 (discussing the "objective probability environment").

168. See Peter J. H ammon, Uncertainty, in THE NEW PALGRAVE, supra note 167, at 728 , 728, 732 (defining "uncertainty" as present whenever "a decision can lead to more than one possible consequence" and discussing the term's relation to subjective probabilities); see also D avidson, supra note 167, at 131 (discussing the "subjective probability environment").

169. The discussion below treats the terms "uncertainty" and "subjective disagreement" as largely synonymous by emphasizing how people disagree in their probability estimates when they have access to differing sets of private information. There is an alternative characterization of "uncertainty," often associated with the economist Frank Knight, which focuses on situations when even a person with access to the common set of all available information might find it impossible to make an estimate of future probabilities. See generally FRA NK H. KNIGHT, RISK, UNCERTAINTY, AND PROFIT 197-263 (1921); see also Davidson, supra note 167, at 131 (discussing the "true uncertainty environment," in which the decisionmaker believes that unforeseeable changes will dictate future outcomes and that no reliable estimate of probabilities can be made). 
B ecause uncertainty permits individuals to hold differing beliefs concerning future probabilities, ${ }^{170}$ the notion of uncertainty as a prerequisite to trade provides a theoretical distinction between $\mathrm{HE}$ trading and risk hedging. A lthough risk hedging obviously requires risk, it does not require uncertainty: so long as two individuals' tastes for risk differ, they can arrange a hedging deal even if they share identical expectations for the probability distribution of future prices. In contrast, HE speculation requires two parties with differing subjective estimates of future probabilities. ${ }^{171}$

W hile the requirement of uncertainty helps to distinguish $\mathrm{HE}$ trading from risk hedging, at least at the theoretical level, the relationship between uncertainty and the information arbitrage approach is more complex. In a sense, the information arbitrage model also implies differences in traders' subjective estimates of future prices. Consider the case of the ignorant farmer who sells wheat at too low a price to an information arbitrageur who accurately predicts an impending shortage: presumably, the farmer would not sell cheaply if she shared the arbitrageur's estimate of future prices. A the same time, the farmer does not so much disagree with the arbitrageur's predictions, as find it uneconomic invest in research. ${ }^{172}$ In effect, the farmer grudgingly chooses to pay the price of ignorance because it would be even more costly for her to do the research necessary to avoid trading at a disadvantage.

Consequently, subjective disagreement alone may not suffice to differentiate $\mathrm{HE}$ trading from information arbitrage. $\mathrm{HE}$ trading also exhibits two additional characteristics that distinguish it from risk hedging and information arbitrage, however. O ne is speculator-withspeculator trading. R ecall the risk hedging and information arbitrage models' predictions regarding the nature of speculators' counterparties. ${ }^{173}$ A ccording to the risk hedging model, speculators trade with

170. In contrast, in an objective probability environment, rational agents make identical estimates of an asset's statistical value. Thus, all rational individuals would place a statistical value of 25 cents on an opportunity to flip a quarter "double or nothing."

171. Uncertainty also provides a distinction between HE speculation and investment. Investors perceive it as being in their interest to defer consumption by purchasing assets that provide a positive return even when they agree with the market's valuation of those assets. Speculators, in contrast, buy an asset when they disagree with its market price.

172. This observation explains why the information arbitrage model is consistent with rational expectations analysis, which predicts that rational individuals should never trade on subjective disagreement. See infra note 184 and accompanying text (discussing the "no-trade" result).

173. See supra notes $147-51$ and accompanying text. 
hedgers who want to protect themselves from future price fluctuations. A ccording to the information arbitrage model, speculators deal with rationally less well informed producers and consumers who decline to invest in available, but costly, predictive information. B oth models thus imply that speculators deal with nonspeculators-traders who are buying and selling for reasons other than the hope of profiting from predicting a shift in market prices.

In contrast, HE transactions can involve speculators on both sides. Thus, in the example presented earlier, bull and bear-both speculators-disagreed in their predictions for the future price of gold, and traded with one another. This analysis suggests that $\mathrm{HE}$ trading can be identified by focusing on the nature of a speculator's counterparty. When a trader acquires superior predictive information and trades profitably with rationally ignorant consumers or producers, the transaction involves information arbitrage. But, if the same trader deals with a counterparty who also expects to reap trading profits because she also believes she has superior predictive information, the transaction is better described by the HE model.

Focusing on the identity of speculators' counterparties helps to explain a third fundamental characteristic of HE trading that distinguishes it from both risk hedging and information arbitrage: speculator error as judged by ex post results. Consider again the case of the bull who anticipates a $\$ 10$ per ounce profit from buying gold and the bear who hopes to avoid a $\$ 10$ per ounce loss by selling. The bull and bear cannot both be right. A Ithough each hopes to reap an expected gain of $\$ 10$ per ounce from their trade ex ante ( $\$ 20$ per ounce total), they necessarily experience an average return of $\$ 0$ : speculation on disagreement is a zero-sum game in which one player's gain is necessarily the other's loss.

Indeed, when HE trading involves transaction costs, speculators' average returns become negative. A ssume that to execute the trades the bull and bear must each pay $\$ 1$ per ounce brokers' commissions. While the traders expect total gains of $\$ 18$ per ounce (each expects a $\$ 9$ net gain), the inevitable result of their trading is a $\$ 2$ per ounce decline in their aggregate wealth. This is because any gain enjoyed by one party has come from the other's pocket, and both have had to pay brokers' fees. ${ }^{174}$

174. See Stout, Casinos, supra note 132, at 670-77 (discussing the negative-sum nature of stock speculation). 
The $\mathrm{HE}$ model of speculation consequently implies that $\mathrm{HE}$ speculators as a class lose wealth as a result of trading. ${ }^{175}$ Some individual traders may win while other lose, but the iron laws of mathematics ensure that when transaction costs are positive, trading makes $\mathrm{HE}$ speculators, on average, poorer. This result poses a stark contrast to the risk hedging and information arbitrage theories, which both predict that speculators as a class should reap trading profits at the expense of their more risk-averse, less well informed counterparties. ${ }^{176}$ It also offers a means of testing the empirical-as opposed to the theoretical-validity of the HE approach.

3. E mpirical Evidence of $\mathrm{HE}$ Trading. If $\mathrm{HE}$ trading is common, we should find evidence of both speculator-with-speculator trading and ex post speculator losses in speculative markets. In fact, the available data strongly suggest that in markets commonly associated with speculation, such as the stock market and organized futures exchanges, both phenomena are present. The vast majority of trading in the stock market, for example, appears driven by investors' hopes to beat the market. ${ }^{177}$ In other words, most investors who buy are acquiring stocks they perceive as underpriced from others who sell because they think the same stocks are overpriced. This sort of speculator-with-speculator trading is difficult to reconcile with the standard risk hedging and information arbitrage theories. In contrast, the $\mathrm{HE}$ model supports the idea of a trading market composed primarily, or even entirely, of speculators hoping to outpredict each other.

Studies also have found that, both in the stock market and on the organized futures exchanges, traders who identify themselves as speculators on average lose money by trading. ${ }^{178}$ This remarkable re-

175. Ex post speculator error can be viewed as a consequence of imperfect information. See infra note 196 and accompanying text (discussing imperfect information as a cause of welfarereducing exchanges).

176. See supra notes $150-51$ and accompanying text.

177. See Stout, Casinos, supra note 132, at 661-67 (reviewing evidence suggesting that the vast majority of trading in the secondary stock market is driven by subjective disagreement). A similar presumption underlies the hedging exception to the common law rule against difference contracts, which reflects the judicial perception that most difference agreements are made between speculators, rather than between a speculator and a hedger. See supra notes 66-67 and accompanying text.

178. See Stout, Casinos, supra note 132, at 663-64 (reviewing evidence that pension funds and mutual funds that try to boost their returns by stock trading on average underperform the market); L ester G. Telser, Why There A re O rganized Futures M arkets, 24 J .L. \& E CON. 1, 9-10 (1981) (reviewing studies finding that speculators in futures markets on average incur losses). 
sult has been paid scant attention by theorists. It nevertheless presents a serious challenge to both the risk hedging model, which predicts that speculators should be paid a premium for bearing risk, and the information arbitrage model, which predicts that arbitrageurs should reap trading profits at their less well informed counterparties' expense. The HE model, in contrast, both explains and predicts the trading losses that speculators as a class experience. ${ }^{179}$

4. Some Objections to the HE M odel: Rational Expectations and Trader $L$ earning. The heterogeneous expectations approach provides an explanation for speculative trading that seems intuitively plausible. M oreover, the idea of HE trading is supported by empirical evidence that seems impossible to reconcile with the risk hedging and information arbitrage theories. Why, then, has the economic literature neglected the HE approach?

Contemporary theorists' reluctance to incorporate expectations heterogeneity into discussions of speculation may be due, in part, to the fact that introducing subjective disagreement can enormously compound the difficulties of mathematically describing rational decisionmaking. In the face of disagreement, elegant and tidy market models can become unruly. Theorists accordingly often prefer to simply assume disagreement away. The standard Capital A sset Pricing Model, for example, expressly assumes that all investors share homogeneous expectations. ${ }^{180}$

A t least two more substantive objections to the HE approach, however, may have contributed to economists' tendency to overlook $\mathrm{H}$ irshleifer's papers on the subject of speculation. The first is associated with a branch of modern game theory known as "rational expectations" analysis. ${ }^{181}$ Shortly after Hirshleifer published his work on speculation, several prominent theorists responded with papers that challenged the idea of disagreement-based trading as inconsistent

179. See infra text accompanying note 286 (discussing how CFTC inquiry into the identity of speculating traders' counterparties and into speculating traders' ultimate success in their quest for profits can help distinguish markets dominated by $\mathrm{HE}$ trading from markets where most speculators are actually information arbitrageurs).

180. See infra notes 212-14 and accompanying text (discussing the standard Capital A sset Pricing M odel).

181. R ational expectations analysis was the basis for a recent $\mathrm{N}$ obel Prize in economics. See Great Expectations, and Rational Too, THE ECONOMIST, Oct. 14, 1995, at 96 (discussing the work of economist R obert L ucas, who was awarded the N obel Prize in 1995). 
with rational expectations. ${ }^{182}$ In the wake of this critique, the idea that disagreeing speculators might trade with each other in mutual expectation of profit largely disappeared from the theoretical literature. ${ }^{183}$

This disappearance may provide an instructive example of the pitfalls associated with economists' fascination with mathematical models. The rational expectations critique of $\mathrm{H}$ irshleifer's $\mathrm{HE}$ model relies on a result known as the "no-trade" theorem. ${ }^{184}$ In brief, the notrade theorem predicts that rational individuals should never trade on subjective differences of opinion. This peculiar result is driven by the idea that speculators who try to predict the future from limited information should realize that their estimates are imperfect, and revise them in the face of another's disagreement. ${ }^{185}$ Thus bulls should refuse to buy when they learn that bears are willing to sell, and vice versa. In effect, each party asks, "what does the other side know that I don't?"

A t a general level, the proposition that traders pay attention to others' behavior seems quite plausible. $Y$ et to reach its counterintuitive result, the no-trade theorem relies on several empirically unlikely assumptions that counsel against dismissing the $\mathrm{HE}$ approach on rational expectations grounds. These include the assumptions of concordant beliefs (meaning that all speculators process information in an identical fashion, and reach the same conclusion given the same data) and common knowledge (meaning that all speculators know that they share concordant beliefs, and all speculators know that all speculators know this, and so on in infinite regress)..$^{186}$ In real mar-

182. See R obert J. A umann, A greeing to D isagree, 4 A N NA LS STA T. 1236, 1236 (1976); J ohn D. Geanakoplos \& Heraklis M. Polmarchakis, We Can't Disagree Forever, $28 \mathrm{~J}$. Econ. THE ORY 192, 192-93 (1982); Paul M ilgrom \& Nancy Stokey, Information, Trade, and Common Knowledge, 26 J. ECON. THEORY 17, 17 (1982); see also J ean Tirole, On the Possibility of Speculation Under Rational Expectations, 50 EconOMETRICA 1163, 1164 (1982) (concluding that "contrary to the Working-H irshleifer-Feiger view, rational and risk averse traders never trade solely on the basis of differences in information") (emphasis omitted).

183. For example, in a search of the LEXIS "LA WREV" database in February 1999, the author was unable to find a single reference to $\mathrm{H}$ irshleifer's work on speculation.

184. See M ilgrom \& Stokey, supra note 182, at 17-18 (discussing the no-trade result).

185. See id. at 18.

186. For example, each of the sources cited supra at note 182 assume concordant beliefs and common knowledge. Concordant beliefs and common knowledge do the work in ensuring that bulls and bears refuse to trade: although the bull might initially believe that gold is likely to rise, he also believes that the bear processes information just as he does, and would not be willing to sell unless she had access to private negative information that would lead the bull also to conclude gold was overpriced. The bull consequently revises his initial optimistic estimate of gold downwards in light of the bear's pessimism, while the bear similarly revises her 
kets, the assumptions of concordant beliefs and common knowledge seem implausible. ${ }^{187} \mathrm{~A} s$ a result, the rational expectations critique of the $\mathrm{HE}$ model is something of a theoretical hothouse flower. Rational speculators certainly should extract information from others' trading behavior and revise their initial expectations to some degree. Their revisions are likely to be only partial, however, and disagreement-based trading accordingly should persist. ${ }^{188}$

There is a second objection that can be raised against the notion of a disagreement-based market, however, that also may have contributed to the hegemony of the risk hedging and information arbitrage models. This second critique relies on the phenomenon of trader learning. O ver a series of repeated transactions, speculators who trade on subjective disagreement should eventually realize that the ex post result of their trading is trading losses, and should stop trading. Thus, the argument goes, HE speculation should extinguish itself over time. ${ }^{189}$

initial pessimistic estimate upwards in the light of the bull's optimism. A s a result, the bull and the bear come to agree in their estimates, and no sale occurs.

187. For example, if speculators believe that some portion of traders in the market are trading for reasons other than a disagreement with market price (e.g., because of changing risk or consumption preferences), then common knowledge is lacking, and trading on disagreement becomes rational. See HIRSHLEIFER, Two Models, supra note 165, at 294-95; Lynn A. Stout, A greeing to D isagree over Excessive Trading, 81 V A . L. REV . 751, 753-54 (1995). A similar outcome ensues if, contrary to the assumption of concordant beliefs, rational people extract differing meanings from the same data. This is because the assumption of concordant beliefs relies on the Bayesian premise that speculators estimating future events all start with identical prior probability estimates, which they then revise in light of sample information. In reality, people with different life experiences are likely to approach speculative markets with markedly different priors, and therefore draw different conclusions from similar data. See L ynn A. Stout, I rrational Expectations, 3 LEGAL THEORY 227, 240-41 (1997).

188. Indeed, any other suggestion appears flatly contradicted by the data. A second consideration arguing against relying on the no-trade result is the overwhelming evidence that people in fact often invest substantial resources on the basis of disagreement. (The present debate over the consequences of speculation is, of course, itself a case in point.) If trading on disagreement is inconsistent with rational expectations, this sort of behavior appears both endemic and predictable.

189. For example, commentators have cautioned that regulators should not draw inferences from the spectacular losses recently reported by many investment funds and corporations that use derivatives, because even if derivatives users may initially mistake the derivatives' value, over time the market should come to be dominated by traders who trade only when it truly serves their interest to do so. See Thomas C. Theobald, Regulatory Chokehold: D erivatives A ren't the D anger, W A LL ST. J., M ay 23, 1994, at A 14 (arguing against derivatives regulation on the theory that "[m]anagers who make informed decisions and have appropriate internal controls in place ... will emerge as winners in the marketplace. Those that don't will be losers, subject to the discipline of the market"). 
Considerable evidence suggests that traders who lose money speculating do, in fact, eventually exit the markets. ${ }^{190} \mathrm{~N}$ evertheless, at least two important considerations suggest that speculative markets can thrive in the face of trader learning. First, learning is more difficult in some markets than in others. For example, the natural volatility of stock prices makes it difficult for losing traders to determine whether their losses are the result of poor prediction or mere chance. ${ }^{191}$ Similarly, learning is likely to be slow in markets where people trade only infrequently, like the residential real estate market. ${ }^{192}$ Second, and perhaps more importantly, the learning critique of the HE model confuses financial "survival of the fittest" with biological survival. Even as one disappointed generation of $\mathrm{HE}$ speculators leaves a market, demographic processes ensure that it will be replaced by a new generation eager to try its hand at trading. $D$ arwin-

190. See Stout, Casinos, supra note 132, at $640 \&$ n.74 (citing evidence that those who lose money trading stocks stop trading); Telser, supra note 178, at 9-10 (reviewing studies finding that larger speculators earn positive returns in futures markets and smaller traders suffer losses, which implies that there may be more turnover among small speculators and that small speculators who are successful become large while those who are unsuccessful leave the market and are replaced by new small speculators); see also JAMES B. WOY, COMMODITIES FUTURES TRADING: A BIBLIOGRAPHIC GUIDE 5 (1976) (citing sources which suggest that "the drop-out rate for beginning commodity speculators is very high"); T reasurers Put Their V iews on Banks, EUROMONEY, M ay 1995, at 65, 68 (positing that in wake of publicized cases of derivatives losses, corporate treasurers have grown extremely cautious about using complex derivatives).

191. Two finance scholars once calculated that it would take twenty-five years for a fund manager who outperformed the stock market by an impressive $2 \%$ each year to establish at a $95 \%$ confidence level that her superior performance was a result of skill rather than luck. See Louis K.C. Chan \& Josef Lakonishok, Are the Reports of Beta's Death Premature?, J. PORTFOLIO MGMT., Summer 1993, at 51, 54.

192. It also appears that experience gained in one financial instrument or strategy does not necessarily carry over to others. For example, in 1987, many stock fund managers learned that "portfolio insurance" strategies involving exchange-traded stock-index futures did not, in fact, protect them against market declines. See G eorge A nders, Investors Rush for Portfolio Insurance, W A LL ST. J ., O ct. 14, 1986, at A 6 (describing the increasing popularity of the practice of selling stock futures to hedge against losses in equities portfolio); G eorge A nders, Portfolio Insurance Failed to Serve as Cushion in Crash, W A LL ST. J ., O ct. 28, 1987, at A 6 (noting that fund managers found portfolio insurance did not protect against losses in 1987 stock market crash); R andall Smith, U se of Portfolio Insurance Fell A fter Crash, W A LL ST. J ., J an. 12, 1988, at $A 4$ (reporting that the use of portfolio insurance shrank by two-thirds or more following the 1987 stock market crash). By the 1990s, however, managers again perceived opportunities to eliminate equities risk through the similar strategy of "dynamic hedging" with "portfolio puts." See K evin G. Salwen \& Craig Torres, Portfolio Insurance Is Back for Stocks in New Guise, W A LL ST. J ., M ay 31, 1990, at C1 (speculating that although traditional portfolio insurance used prior to the 1987 stock market crash is "almost defunct," institutions now attempt dynamic hedging against stock market declines through portfolio puts). 
ian selection cannot reasonably be expected to eliminate $\mathrm{HE}$ trading. ${ }^{193}$

A closer examination of the trader learning argument accordingly suggests that disagreement-based speculation can persist in a variety of markets despite the likelihood that losing speculators will stop trading eventually. A the same time, trader learning also implies that $\mathrm{HE}$ trading may be more common in some markets, and among some sorts of traders, than others. Part IV considers in greater detail how this observation may offer insights to regulators seeking to deter HE speculation in the market for OTC derivatives. ${ }^{194}$

\section{B. Normative Implications of the HE M odel}

Thus far, the analysis has focused on developing the $\mathrm{HE}$ model of speculation as a theoretical alternative to conventional theories, as well as considering some of its positive insights into speculative markets. The HE approach also carries vital normative implications, however. This is because the $\mathrm{HE}$ model contradicts the risk hedging model's prediction that speculation benefits the trading parties, by suggesting how speculation can reduce average trader welfare. Further, it undermines the information arbitrage model's prediction that speculation improves price accuracy, and in fact explains how speculation may reduce it. In other words, the $\mathrm{HE}$ model suggests that speculative trading-whether in stocks, real estate, or derivativescan be economically inefficient.

1. HE Trading and Trader Welfare. Neoclassical economic theory generally assumes that voluntary exchange benefits both sides to a transaction. ${ }^{195}$ The risk hedging model of speculation fits neatly into this view by predicting that risk hedging, on average, benefits both hedgers and their speculating counterparties. Hedgers are happy to pay to avoid risk, while less risk-averse speculators are happy to be paid a premium to bear it. In contrast, the HE model paints a darker

193. See Stout, Casinos, supra note 132, at 637-41 (explaining why investor learning should not be expected to eliminate speculative trading).

194. See, e.g., infra notes 295-302 and accompanying text.

195. Neoclassical theory also recognizes, however, that in the face of incomplete and heterogeneous information, rational parties may expect benefits from exchange ex ante that fail to materialize ex post. Consider, for example, the case of the consumer who buys tainted milk. 
picture of speculation's effects by suggesting how speculative trading may inefficiently reduce trader welfare. ${ }^{196}$

The HE model predicts that trading driven by subjective disagreement can have the perverse effect of harming trader welfare through two distinct mechanisms: first, by reducing traders' wealth through trading that produces a net negative return; and second, by increasing traders' exposure to risk. ${ }^{197}$ Focusing first on the issue of $\mathrm{HE}$ traders' returns from trading, recall that when transaction costs are positive, disagreement-based trading inevitably reduces participants' aggregate monetary wealth. ${ }^{198}$ Some individual traders may win while other lose, but transaction costs ensure that traders as a class lose money by trading. Of course, risk hedging deals also involve transaction costs that reduce trader wealth. The parties to a risk hedging transaction, however, generally enjoy ex post the riskshifting benefits they anticipated and were willing to pay for ex ante. A s a result, risk hedging reallocates resources in a fashion that increases their value as measured by individuals' willingness to pay for them. In contrast, HE speculators hope to become richer by trading on their contrary predictions, yet find themselves, on average, poorer. This curious result produces the prediction that heterogeneous expectations trading decreases the ex post monetary wealth-and welfare - of speculating traders.

Second, and more subtly, disagreement-based trading also carries the potential to reduce trader welfare by increasing risk, because the perceived opportunity to profit from predicting future prices can tempt HE speculators into volatile markets that they would otherwise avoid, just as it tempts them into paying transaction costs that they would otherwise avoid. ${ }^{199}$ Consider the example of the speculator

196. A s in the case of the purchase of tainted milk, this ex post speculator error can be described as a consequence of imperfect information. Given perfect information regarding the future, bull and bear both would know whether gold prices were going to rise or fall. No trade would occur because if one were willing to buy the other would be unwilling to sell, and vice versa. However, since imperfect information permits subjective disagreement, bull and bear each perceive opportunities to extract trading profits from the other despite the zero-sum nature of such transactions.

197. Modern portfolio theory predicts that rational traders should care about only two variables when choosing a trading strategy: the likely returns from the strategy, and the likely risk of those returns. See generally BREALEY \& MYERS, supra note 7, at 173-83 (describing the birth of portfolio theory and the relationship between risk and return). Since returns are good and risk is bad, traders accordingly try to maximize returns while minimizing risk.

198. See supra text accompanying note 174 .

199. See L ynn A. Stout, B etting the Bank: H ow D erivatives Trading Under Conditions of 
whose wealth is already concentrated in gold. Portfolio theory cautions the speculator to reduce the risk of his portfolio by diversifying, selling gold to buy other investments such as stocks or diamonds. ${ }^{200}$ If the speculator expects gold prices to soon rise, however, he may buy more gold, increasing the risk of his portfolio. ${ }^{201}$ Similarly, corporate executives, municipal treasurers, and investment fund managers who believe that they can predict future interest rates or market prices may choose to negotiate derivatives deals that increase their institutions' risk exposure, believing that they will reap trading profits that compensate for the increased risk. ${ }^{202} \mathrm{U}$ nfortunately, when speculators are really $\mathrm{HE}$ traders, this belief is statistically mistaken.

Trading on subjective disagreement can accordingly reduce trader welfare by tempting otherwise risk-averse traders into accepting uncompensated risks. While these welfare losses may be more difficult to quantify than wealth losses due to HE trading, they are just as real. In illustration, Part IV returns to consider in greater detail the case of speculative trading in OTC derivatives.

2. HE Trading, Price A ccuracy, and Speculative Bubbles. By explaining how disagreement-based speculation can reduce traders' monetary wealth while increasing their risk, the HE model offers a striking counterpoint to the risk hedging model's prediction that speculation improves trader welfare. M utually beneficial risk shifting is not the only efficiency benefit economists associate with speculation, however. A ccording to the information arbitrage model, speculation also serves allocative efficiency by promoting "informational" or "pricing" efficiency-i.e., by improving the accuracy of market prices.

Uncertainty Can Increase Risks and E rode Returns In Financial M arkets, 21 J. CORP. L. 53, 62 63 (1995) (arguing that the HE model suggests that opportunities for derivatives speculation can increase the average trader's assumed risks and reduce his returns by increasing transaction costs).

200. Because the prices of the other investments are likely to vary in different patterns from gold prices (e.g., stock prices rise when gold prices fall), diversifying an asset portfolio can reduce its overall risk or variation. See generally BREALEY \& MEYERS, supra note 7, at 153-65 (discussing how diversification reduces risk).

201. This point should not be overstated. Sometimes subjective disagreement with market prices can lead a trader to reduce risk, as when a gold bull becomes bearish, and sells. A s a general matter, however, HE speculation seems likely to increase traders' risk by tempting them into volatile markets they otherwise would avoid.

202. See infra notes $271-73$ and accompanying text (discussing recent examples in which derivatives speculation increased an institution's risk exposure, in some cases leading to bankruptcy or near-bankruptcy). 
In a market where speculators are truly information arbitrageurs armed with superior knowledge about the future, speculation should indeed shift prices to more accurately reflect the underlying forces of supply and demand. ${ }^{203}$ The HE model of trading suggests, however, that traders who believe they have superior information can be mistaken in their belief. Their information is not superior to the information of other traders; it is merely different. This possibility challenges the conventional presumption that speculators improve the accuracy of market prices.

The $\mathrm{HE}$ model undermines the claim that speculators improve market prices because under the HE model, speculators who trade on subjective disagreement with market prices are just as likely to be wrong as right. ${ }^{204}$ Thus there is no reason to believe a priori that a market price influenced by $\mathrm{HE}$ traders' bullish and bearish opinions will be any more accurate than the price set in a market composed only of actual producers and consumers. ${ }^{205} \mathrm{U}$ nlike true information arbitrage, HE speculation does not produce a social benefit in the form of better pricing.

In lawmakers' eyes, however, speculators traditionally have been perceived as guilty of more than just failing to improve market prices. To the contrary, speculators have often been accused of triggering speculative price "bubbles" - instances where market prices rise suddenly, inexplicably, and unreasonably before the bubble bursts and prices return to earlier levels. The most famous example may be the 1637 D utch tulip bulb frenzy. D uring the course of this "tulipmania," the price of common tulip bulbs rose twenty-fold before abruptly sinking again to previous levels. ${ }^{206}$

203. This is not to say that prices in a market deprived of information arbitrageurs would be completely divorced from economic reality; presumably, consumers and producers also invest some effort in valuing the goods and services they trade. R ecognizing that consumers and producers do not necessarily need information arbitrageurs to value assets helps explain why the private costs of information arbitrage can outweigh its public benefits. See supra note 154 and accompanying text (discussing the possible inefficiency of information arbitrage).

204. A fter all, when a bull predicts that prices will rise while a bear predicts a fall, at least one must be mistaken.

205. Cf. Lynn A. Stout, Technology, Transactions Costs, and Investor Welfare: Is a M otley Fool Born Every M inute?, 75 W A SH. U . L.Q . 791, 801-02 n.24 (1997) [hereinafter Stout, Technology] (criticizing the argument that adding speculators to the market increases the accuracy of prices by increasing the size of the sample from which average opinion is drawn).

206. See Peter M. G arber, Tulipmania, 97 J. PoL. E con. 535, 556 (1989). 
Scholars who study markets have shown an enduring fascination with bubbles. ${ }^{207}$ Because most find the idea of bubbles difficult to reconcile with conventional pricing theory, some have questioned whether bubbles really occur, arguing that reported bubbles in the markets for art, real estate, and so forth actually reflect the impact on prices of important new information-information that academics, presumably, are unable to detect. ${ }^{208} 0$ thers have suggested that bubbles prove that some traders are irrational. ${ }^{209} \mathrm{Y}$ et a third approach is reflected in the growing literature that explains price bubbles as selffulfilling prophecies, the rational by-products of expectations that prices will soon deviate from fundamental values. ${ }^{210}$ These "rational bubble" theories have been criticized, however, for failing to explain how deviations from fundamental value initially arise. ${ }^{211}$

207. See generally id. at 536 n.2 (discussing historical examples of speculation that economists have classified as bubbles); BURTON G. MALKIEL, A RANDOM WALK DOWN WALL StREET 34-53 (6th ed. 1996) (same).

208. See, e.g., R obert P. Flood \& R obert J. H odrick, On Testing for Speculative Bubbles, J . ECON. PERSP., Spring 1990, at 85, 87 (contending that bubble findings can be explained as results of model misspecification or market fundamentals).

209. See, e.g., D avid M. Cutler et al., Speculative D ynamics and the R ole of F eedback Traders, 80 A M. E CON. REV. 63, 65 (1990) (discussing irrational "feedback" traders); J . Bradford D e L ong et al., Positive F eedback Investment Strategies and D estabilizing Rational Speculation, 45 J. FIN . 379, 393-94 (1990) (attributing bubbles to irrational "noise" traders).

210. See Robert P. Flood \& Peter M. Garber, Bubbles, Runs, and Gold Monetization, in Crises IN THE ECONOMIC ANd Financial Structure 275, 276 (Paul Wachtel ed., 1982) [hereinafter CRISES] (defining a price bubble as when "the arbitrary self-fulfilling expectation of price changes may drive actual price changes independently of market fundamentals"); see also Costas A zariadis, Self-Fulfilling Prophecies, 25 J. ECON. THEORY 380, 388-90 (1981) (showing that self-fulfilling prophecies occur frequently due to "extraneous uncertainty"); OIiver J. Blanchard \& M ark W. Watson, Bubbles, Rational Expectations, and Financial Markets, in CRISES, supra, at 295, 296-301 (explaining how bubbles proceed independently of an asset's fundamental value); B ehzad T. Diba \& Herschel I. Grossman, Rational Inflationary Bubbles, 21 J. MONETARY ECON. 35, 38 (1988) (demonstrating the self-confirming nature of rational bubbles).

211. See, e.g., K enneth A. Froot et al., H erd O $\mathrm{n}$ The Street: Informational Inefficiencies in a Market with Short-Term Speculation, 47 J. FIN. 1461, 1479 (1992) (arguing that the "rational bubble" model "offers no mechanism for what drives the market away from efficiency"); Leach, supra note 141, at 132 (questioning how the model would explain what initiates bubbles); see also M.C. A dam \& A. Szafarz, Speculative Bubbles and Financial Markets, 44 OXFORD E CON. PA PERS 626, 637-38 (1992) (concluding that rational expectations bubble theories do not fit the traditional conceptions of bubbles). The HE approach complements rational bubble theory by explaining why rational speculators might expect market prices to deviate from fundamental values. In particular, the HE approach suggests that in an incomplete market, an increase in uncertainty can produce price shifts that appear unjustified to the average observer. See infra notes 227-32 and accompanying text (discussing HE bubbles). 
O ne reason why bubbles have presented such a problem for theorists is that most analyses rely, implicitly or explicitly, on asset pricing models that assume homogeneous expectations. ${ }^{212}$ Such models generally predict that market prices reflect the best possible estimates of assets' fundamental values. ${ }^{213}$ A Ithough closer inspection reveals that this result is nearly a tautology (if all traders share identical expectations for a particular asset's future risks and returns, why wouldn't the market price mirror that consensus?) it nevertheless makes bubbles seem difficult to explain.

$Y$ et while pricing models that assume homogenous expectations remain a staple of introductory finance texts, ${ }^{214}$ a large and growing literature has begun to address how asset prices are set under conditions of expectations heterogeneity. ${ }^{215}$ These $\mathrm{HE}$ pricing models can explain a variety of otherwise puzzling market behaviors, including speculative bubbles. ${ }^{216}$ In illustration, the discussion below presents a simple example of a bubble in a market where individuals have heterogeneous expectations. A Ithough this example does not offer an definitive explanation for all bubbles ${ }^{217}-$ a full discussion of the na-

212. The classic example is the standard Capital A sset Pricing Model (CAPM). See BREALEY \& MEYERS, supra note 7, at 180-90 (describing CA PM, which predicts a linear relationship between return and risk).

213. See, e.g., id. at 337 (relying on homogeneity-based model for the proposition that one should always trust prices in an efficient market). B ut see $L$ ynn $A$. Stout, $H$ ow E fficient $M$ arkets Undervalue Stocks: CA PM and ECM H Under Conditions of Uncertainty and Disagreement, 19 CARDOZO L. REV. 475, 480-81 (1997) [hereinafter Stout, CAPM and ECMH] (arguing that while CA PM remains useful for describing a rational investor's attitude toward risk versus return, the model should not be relied upon as evidence that market price necessarily reflects an investment's intrinsic value).

214. See, e.g., BREALEY \& MEYERS, supra note 7, at 180-90 (presenting CA PM).

215. See, e.g., William F. Sharpe, Portfolio Theory and Capital Markets 104-13 (1970); J ohn L intner, The A ggregation of Investor's [sic] Diverse J udgments and P references in Purely Competitive Securities M arkets, 4 J. FIN. \& Q UANT. A NA LY SIS 347 (1969); E dward M. M iller, Risk, Uncertainty, and Divergence of O pinion, 32 J. FIN. 1151 (1977); Lynn A. Stout, A re Takeover Premiums Really Premiums? M arket Price, Fair Value, and Corporate L aw, 99 Y A LE L.J . 1235 (1990) [hereinafter Stout, Takeover Premiums]; Hal R. V arian, D ivergence of O pinion in Complete M arkets: A N ote, 40 J. FIN. 309 (1985); J oseph T. Williams, Capital A sset P rices with H eterogeneous B eliefs, 5 J . FIN. E CON 219 (1977). This body of work addressing the problem of equilibrium asset pricing under conditions of heterogeneity presents an interesting contrast to academic discussions of speculation, which tend to ignore disagreement's role in inspiring trading.

216. See Stout, CAPM and ECM H, supra note 213, at 479 (discussing how heterogeneous expectations models can explain a variety of market anomalies).

217. B ecause the example assumes obstacles to short selling, it may not provide a good description of price bubbles in assets with well-developed futures or options markets. However, the example may shed light on a variety of reported instances of speculative bubbles in spot 
ture and causes of asset price distortions under conditions of subjective disagreement lies beyond the scope of this A rticle-it illustrates how $\mathrm{HE}$ theory supports the traditional association between speculators and price distortions. ${ }^{218}$

The example begins with the assumption that there are obstacles to short selling (i.e., selling borrowed assets) ${ }^{219}$ A s discussed in Part I, federal securities law imposes significant restrictions on speculators who want to sell short in the stock market. ${ }^{220}$ A lthough bearish speculators who deal in other assets do not face this legal hurdle, practical difficulties severely limit short selling in most spot markets. For example, a bull who wants to "go long" in real estate or fine art must arrange only two transactions: a purchase, and a sale. In contrast, a bear who wants to short property she doesn't already own must arrange four transactions: a loan, a sale, a purchase, and then a return of the borrowed asset. Short sellers' transaction costs are correspondingly higher, ${ }^{221}$ especially because there are few organized

markets, such as the tulip frenzy. M oreover, finance scholars have begun to use the HE approach to develop bubble models that do not depend on short sales restrictions. See, e.g., J ack Treynor, Bulls, Bears, and Market Bubbles, FIN. A NALYSTS J., Mar.-A pr. 1998, at 69, 71 (examining bubbles in a complex model that relies on wealth effects).

218. In addition to their supposed role in unintentionally sparking price bubbles, speculators are often accused of deliberately manipulating market prices through such schemes such as "corners" and "squeezes." See generally Jerry W. Markham, Manipulation of Commodities Futures Prices-The Unprosecutable Crime, 8 Y A LE J. ON REG. 281 (1991) [hereinafter M arkham, M anipulation] (discussing commodities manipulation); W endy Collins Perdue, M anipulation of Futures Markets: Redefining the Offense, 56 FORDHAM L. REV. 345 (1987) (same); $D$ aniel R. Fischel \& David J. R oss, Should the $L$ aw Prohibit "M anipulation" in Financial M arkets?, 105 HARV. L. REV. 503 (1991) (discussing manipulation of securities and commodities markets); Steve Thel, $\$ 850,000$ in Six M inutes-The M echanics of Securities M anipulation, 79 CORNELL L. REV. 219 (1994) (discussing manipulation in securities trading).

219. HE pricing models generally must employ one of a number of reasonable assumptions of market incompleteness (e.g., risk aversion, wealth limitations, or short sales restrictions). The need for such assumptions becomes apparent if we return to the gold-trading example and assume that the bull who perceives an opportunity to reap certain profits of $\$ 10$ per ounce by buying "underpriced" gold is willing to commit all his wealth and an infinite amount of borrowed wealth as well to that purpose. If the bear similarly is willing to sell an infinite amount, trader disagreement prevents equilibrium. Bull and bear will, in effect, take infinite bets against each other. Incomplete markets, in contrast, limit traders' willingness or ability to take infinite positions, and thus permit equilibrium prices to exist in the face of disagreement. However, prices under such conditions may not necessarily equal the best estimate of value given all available data. See generally authorities cited supra notes 215 and 217 (discussing asset pricing under heterogeneous expectations).

220. See supra notes $121-28$ and accompanying text.

221. A ny attempt to circumvent such costs by entering an off-exchange agreement for payments contingent on price changes runs afoul of the rule against difference contracts and its 
borrowing markets outside the securities markets. ${ }^{222}$ These and other difficulties ensure that short selling is generally difficult and expensive. ${ }^{223}$

The net result is a selection bias that may offer an elegant and intuitive explanation for many speculative bubbles, because it implies that adding disagreeing $\mathrm{HE}$ speculators to an asset market previously comprised only of producers and consumers can inflate market prices. To see how this works, consider a simple three-period example in which the arrival and subsequent resolution of uncertainty induces speculators first to enter, and then to depart, the gold market. ${ }^{224}$ A ssume that in the first period, all individuals share homogeneous expectations for the future price of gold-all expect gold to continue to trade at its current market price of $\$ 500$ per ounce, as determined by preferences and production costs. A s result there is no disagreement and no speculation. The only individuals who purchase gold are those who extract consumption value from it or plan to use it as a productive input (e.g., jewelers and dentists).

In period two, new information arrives that creates uncertainty about future gold prices- perhaps the market receives news of a military coup in some gold-producing nation. A ssume that the new information changes the expectations of only two individuals in the market. O ne predicts gold production will fall, and prices will rise from $\$ 500$ to $\$ 510$ per ounce in the next period; the second predicts an increase in production, so that price will fall to $\$ 490$. The expecta-

modern descendant, the Commodity Exchange A ct. See supra Part I.A and notes 88-91 and accompanying text (describing the common law and modern statutory prohibitions).

222. In contrast to speculators who go long (who can usually take advantage of preexisting spot markets developed to serve producers and consumers), speculators seeking to borrow assets to sell short may have to incur substantial search and negotiation costs to arrange a loan.

223. The relative thinness of the asset borrowing market also increases the risk that a short seller will fall victim to a "short squeeze" or similar manipulative scheme. For example, the 1992 Salomon Brothers Treasury Note trading scandal was allegedly part of a scheme to squeeze dealers who had shorted Treasury N ote futures. See M A RTIN M A YER, NIGHTMARE ON Wall Street: Salomon Brothers and the Corruption of the Marketpla Ce 191-197 (1993); see also R ichard T. Baillie et al., B ear Squeezes, Volatility Spillovers and Speculative A ttacks in the Hyperinflation 1920s Foreign Exchange, $12 \mathrm{~J}$. INT'L MONEY \& FIN. 511, 512 (1993) (describing the practice of a "bear squeeze").

224. The example will incorporate a number of strong assumptions, including the assumptions of no short selling, first and final periods of absolute certainty and homogeneous expectations, uncertainty that increases the dispersion of traders' expectations but does not change average expectations, and an asset supply sufficiently limited so that a speculator can "corner the market" and determine prices. These assumptions are adopted for ease of illustration only. Similar results are produced even if these assumptions are relaxed, although the analysis becomes more complicated. 
tions of all others in the market remain unchanged. The ambiguous new information consequently has increased the dispersion of expectations in the market without changing the average expectation, which remains $\$ 500$ per ounce.

The arrival of uncertainty and subjective disagreement in period two means that there now exists a bull who expects gold prices to rise, and a bear who predicts prices will fall. B oth perceive opportunities to reap speculative profits by trading on their differing predictions. If short sales are restricted, however, bull and bear face asymmetrical trading opportunities. While the bull can easily go long and acquire gold, the bear's options are much more limited; unless she already holds gold, she cannot sell on her prediction of a price decline. Thus, the only speculator who enters the market will be the bull who expects prices to rise. ${ }^{225}$

The entry of an optimistic speculator into a market previously composed only of consumers and producers puts upward pressure on prices even if the average price expectation remains unchanged. This is because the available supply of gold will move into the hands of the bull, whose reservation price for gold is $\$ 510$ per ounce. So long as he believes his own forecast, he will not willingly part with gold for less. Thus, gold prices rise in period two in a bubble that appears- to the average individual - to be an unjustified response to the ambiguous news of the coup.

Selection bias may explain the initial appearance of a speculative bubble, but why does the bubble burst? J ust as the arrival of uncertainty and disagreement can precipitate a bubble, the resolution of uncertainty can cause the bubble to disappear. A ssume that after the price rise observed in period two, the market receives new information in the third period that resolves much of the uncertainty created by the coup-perhaps time has passed, and the new regime has become more settled and predictable. A ssume also, for simplicity's sake, that the traders' original responses to uncertainty prove to have been unbiased, so that the elimination of disagreement does not change the average expectation, which remains $\$ 500$ per ounce. Bull and bear both learn they were mistaken to expect a change in gold

225. A similar selection bias is responsible for the "winner's curse" that has been repeatedly observed in auctions, where the procedure of selling to the highest bidder tends to produce an auction price exceeding the average bidder's estimate of value. See generally RICHARD H. Thaler, The Winner's Curse: Paradoxes and Anomalies of Economic Life 50-62 (1992) (describing the winner's curse and considering whether it is consistent with rational expectations). 
production, and revise their expectations to agree with the average expectation. Period three, like period one, is characterized by certainty and subjective agreement. A II individuals, including the former bull, now expect gold to trade at $\$ 500$ per ounce. The price of gold accordingly declines.

This simple bubble example offers a host of useful lessons. First, it implies that bubbles can be a predictable consequence of increased uncertainty that invites a self-selected group of optimistic speculators into an asset market where short selling is restricted. In other words, a price bubble-a price rise that appears unjustified in average opinion-can be produced simply by increasing the dispersion of subjective expectations for future prices. ${ }^{226}$ The bubble is driven by the selection bias inherent in a market price set by the optimistic tail of a distribution that is "stretched" when increased uncertainty increases the dispersion of expectations. Indeed, even news that lowers the average individual's expectations might spark a bubble if it greatly increased the dispersion of expectations. This analysis suggests that any development that increases the dispersion of expectations can precipitate a bubble. ${ }^{227}$ For example, a shift in previously stable consumer preferences might trigger a bubble by creating uncertainty about future preferences. This may explain the Dutch tulipmania, which appears to have been an overreaction to the appearance of a fashion fad among French ladies who took to wearing tulips in their gowns. ${ }^{228}$

The example also suggests an explanation of how speculation on disagreement may not only fail to improve the accuracy of market prices, but sometimes may actually distort them. When short sales are

226. Similarly, new information that increases certainty compacts the distribution and brings prices back to their earlier range.

227. The HE model thus generates testable predictions concerning the circumstances likely to favor bubbles. In particular, it predicts that bubbles can be a natural consequence of exogenous technological or economic developments that increase expectations heterogeneity, inviting speculators into markets originally composed primarily of consumers and producers. In other words, bubbles are triggered by uncertainty-increased dispersion of subjective probability estimates-rather than mere risk. E ven if the price of a particular good or service has been historically volatile, bubbles are unlikely when traders share similar expectations for the probability distribution of future prices. Thus bubbles should occur less frequently in markets for agricultural products such as wheat or corn, where prices vary considerably according to weather patterns but where traders have access to extensive common information regarding price volatility. On the other hand, risky prices can contribute to the incidence of speculation in a particular market by slowing the learning process that eventually drives unsuccessful speculators from the market. See supra notes 190-93 and accompanying text.

228. See $G$ arber, supra note 206 , at $543 \&$ n.22. 
restricted, adding a self-selected group of optimistic speculators to a market previously composed of consumers and producers can raise the market price, even when the average of all individuals' estimates of value remains unchanged. $Y$ et if individuals' estimation errors tend to be unbiased, the average of their expectations is more likely to be an accurate measure of value than any individual expectation. ${ }^{229}$ Thus, speculation that raises market price above the average expectation seems likely to decrease the accuracy of prices, with a corresponding decrease in allocative efficiency. ${ }^{230}$

The argument that speculators can distort market prices is subject to an important caveat, however. It should be noted that the type of bubble examined above relies on two preconditions: subjective disagreement, and short sales restrictions. A s a result, a bubble can be said to be caused as much by the incomplete nature of a market where short selling is restricted, as by the phenomenon of speculation itself. This suggests that when it is difficult or impossible to discourage bullish HE speculators from entering a market, a second-best means of preventing bubbles might be to open the door to bears as well, by helping them avoid the costs associated with shorting in the spot market. In other words, some types of price bubbles can be best avoided not by discouraging speculation, but by encouraging short sales. The 1637 tulip bubble, for example, burst shortly after D utch traders developed an options market that made shorting tulip bulbs much easier. ${ }^{231}$

229. A s a result, HE pricing models can explain a variety of pricing "anomalies" that have been observed in highly-speculative markets. For example, HE pricing models have been offered in explanation of the "small-firm effect" and the "neglected-firm effect" in stock markets, as well as instances of negative risk premia contrary to the dictates of the CA PM. See Stout, Takeover Premiums, supra note 215 , at 1257 \& n.112; see also M iller, supra note 215 , at 1155 (discussing how differences in opinion may explain puzzling stock market behavior).

230. This analysis relies upon a presumption that short sales restrictions are less important in markets composed entirely of individuals who actually produce or consume an asset, because someone who becomes bearish in such a market is much more likely at any point to actually own the asset she wants to sell. A s a result, bears often don't need to borrow the assets they want to "short" - instead they can simply sell what they already own. Prices set in a market composed entirely of producers and consumer consequently are more likely to approximate the average of all expectations than are prices set in a market dominated by an optimistic subset of speculators.

231. See G arber, supra note 206, at 543. A rising demand for tulips due to French fashion appears to have driven the tulipmania by inviting a general class of speculators into the $D$ utch tulip bulb market, which was previously limited to professional growers. See id. \& n.22. D uring the height of the Dutch tulip frenzy, the absence of a well-developed borrowing market may have made it difficult for pessimists to sell short on their bearish opinions. See id. at 544. 0 ptimistic speculators who expected tulip prices to rise still further, however, could and did go long. 
The HE model consequently implies that under some circumstances, opening the door to bearish speculators through futures and options trading can improve the accuracy of market prices through a mechanism quite different than that described by the information arbitrage model. A t the same time, the heterogeneous expectations approach also suggests that, under other circumstances, opening futures and options markets can decrease price accuracy even as it reduces obstacles to short selling. Futures and options trading decreases the marginal cost of speculation. A s a result, allowing futures and options trading may draw a larger number of individuals into a particular market, increasing the range of traders' opinions. O nce composed of optimists and pessimists, the larger market now includes the wildly optimistic and wildly pessimistic as well. If any differential persists between the costs of going long and the costs of selling short, such an increase in the dispersion of opinions may increase, rather than decrease, the likelihood of bubbles. ${ }^{232}$ The net result is that asset pricing models that recognize that traders have heterogeneous expectations offer a much more uncertain view of whether speculative trading generally, or speculative trading through futures and options in particular, is likely to increase or decrease the accuracy of market prices. Part IV returns to consider in greater detail some of the implications of this result for the regulation of speculative trading in OTC derivatives.

\section{Summary: The HE M odel and the Common L aw Conception of Speculation}

It should now be apparent that an analysis of speculation that incorporates the reality of expectations heterogeneity offers a way of thinking about speculative markets that is more complex, but also

\footnotetext{
See id. at 543-45. Thus, in accord with HE theory, tulip bulb prices rose in an exaggerated and unjustified bubble. See id. A Iso in accord with HE theory, the development of a bulb futures market, which might have increased opportunities for short selling, may have contributed to the bursting of the tulip bubble. See id. Thus formal futures markets for bulbs were developed in the summer of 1636 and became "the primary focus of trading before the [price] collapse in February 1637." Id. at 543.

232. In any case, because futures and options decrease the marginal cost of speculation for bulls as well as bears, allowing such trading seems likely to increase both the number of $\mathrm{HE}$ traders in the market and the frequency of their trading, possibly producing an increase in traders' welfare losses that outweighs any resulting price accuracy benefit. See generally Stout, Technology, supra note 205, at 808-10 (discussing how the reduction of transaction costs can increase welfare losses from speculation when the demand for speculative trading is highly elastic).
} 
more realistic, than the simple "speculation is efficient" claim associated with conventional theory. This more nuanced perspective warns both against assuming that speculation increases traders' net welfare, as predicted by the risk hedging model, and against the idea that speculation promotes correct pricing, as suggested by the information arbitrage model. To the contrary, disagreement-based speculation may reduce traders' net welfare and decrease the accuracy of market prices. These results present a striking challenge to the standard view that speculation furthers efficiency. They also provide a solid theoretical foundation for the legal hostility towards speculators described in Part I. ${ }^{233}$

Consider first lawmakers' traditional belief that speculation is "nonproductive." A s noted earlier, this notion conflicts with both the risk hedging model and the information arbitrage approach, as both predict that speculation serves allocative efficiency. By predicting that trading on disagreement can reduce average trader welfare and distort prices, however, the heterogeneous expectations approach supports the view that speculation is a nonproductive-indeed potentially destructive-activity.

Similarly, the HE model also may explain the charge that speculation contributes to poverty among speculators. This charge can be recharacterized as a claim that speculation increases the level of risk found in the market. A lthough such a suggestion contradicts the risk hedging model's prediction that speculation reduces aggregate risk, the HE model supports the idea that speculation can tempt even risk-averse individuals into riding the markets' changing tides, creating both more millionaires and more paupers.

Finally, the HE approach provides theoretical support for the third form of economic harm traditionally associated with speculation-price bubbles. A sset pricing models that recognize the reality of subjective disagreement offer the unsettling prediction that speculative trading can sometimes improve, and sometimes harm, the accuracy of market prices. A Ithough this indeterminate result may be intellectually unsatisfying, it supports the idea of a link between speculators and bubbles, by explaining how price increases can be triggered by optimistic speculators' entry into markets previously dominated by producers and consumers. ${ }^{234}$

233. See supra notes 54-62 and accompanying text.

234. See A dam \& Szafarz, supra note 211 , at 637-38 (concluding that rational expectations bubble theories do not fit the traditional conception of bubbles). 
In sum, the HE model of speculation suggests that common sense and the common law may be far more solidly grounded in the economic realities of the market than conventional economic theory would appear to suggest. That possibility raises questions about the wisdom of the modern trend of discounting the value of legal barriers to speculation and even, in some cases, removing them. In illustration, the next Part considers lawmakers' response to the growth of the market for derivatives.

\section{He Speculation and the Market for OTC Derivatives}

Commentators sometimes use the word "derivative" to describe any contract whose value depends on (is derived from) the spot market price of an underlying good or service. ${ }^{235}$ B ecause this broad definition encompasses both forward contracts for the sale of goods to be delivered in the future, and exchange-traded futures and options, derivatives of agricultural and industrial commodities such as grain and copper have in fact been traded for centuries. ${ }^{236}$ In recent years, however, there has been an explosion in trading of contracts whose values are based on financial instruments such as currencies, corporate stocks, stock indexes, and debt obligations. Some of these "financial derivatives" take the form of standardized futures and options listed for trading on a regulated exchange. ${ }^{237}$ The much larger market, however, is the market for individually and privately negotiated over-the-counter (OTC) transactions. ${ }^{238}$

The sudden appearance of a thriving OTC market in financial derivatives raises a host of policy problems for regulators. For example, the Internal R evenue Service has been called upon to clarify de-

235. See $\mathrm{Hu}, \mathrm{M}$ isunderstood Derivatives, supra note 7, at 1464-65 (explaining that a "defining characteristic" of derivatives is that their value depends on changes in the price of an underlying asset).

236. See supra note 231 (describing options markets for tulip bulbs in 1637).

237. The second most frequently traded contract on the Chicago M ercantile Exchange, for example, is a futures contract based on the stocks comprising the Standard \& Poor's 500 Index. SeeFUTURES INDUSTRY A SSOCIATION, supra note 91 , at 8.

238. For example, two of the largest derivatives markets are the off-exchange "interbank" market for foreign currency futures and options and the OTC market for "swaps." See Tormey, supra note 9, at 2357-58 (describing the global interbank currency market); infra notes 243-44 and accompanying text (describing the swap market); see also J erry W. M arkham, Confederate B onds, supra note 161, at 3 (noting that in 1991, the OTC swaps market alone was as large as the regulated exchange market). 
rivatives' tax treatment, ${ }^{239}$ the SE C has adopted rules outlining corporations' obligations to disclose their derivatives use to investors, ${ }^{240}$ and the Federal Reserve has been forced to revise the capital requirements it imposes on banks and other financial institutions. ${ }^{241}$ In addition to these regulatory issues, however-and perhaps more significantly in terms of derivatives' ultimate effect on the economyOTC derivatives raise serious questions about the continued efficacy of A merican antispeculation laws.

\section{A. OTC D erivatives as O ff-E xchange F utures and O ptions}

D erivative agreements generally create either an obligation, or an option, to make or receive payments determined by the future price of some underlying currency, debt obligation, stock, or stock index. ${ }^{242}$ A s this description implies, derivatives are futures and options that are not generally settled by actually delivering the underlying financial instrument. Instead, they are settled through a cash payment or series of cash payments determined by changes in the market price of the underlying instrument.

Consider one of the most common derivative forms, the interest rate "swap." ${ }^{243}$ In a typical swap, Firm A exchanges its promise to pay a fixed rate of interest-say, $7 \%$ annually on a $\$ 100,000$ underlying "notional" amount-for firm B's promise to pay a floating interest rate on an equivalent notional amount. To accomplish the same result in the spot market for corporate debt, Firm A would have to issue a $\$ 100,000$ bond at $7 \%$ interest, and then buy another firm's $\$ 100,000$ floating-rate bond. In the swap market, however, A and B can avoid actually transferring the underlying $\$ 100,000$ by simply

239. See IRS I ntroduces D erivatives Pricing M odel, but $M$ any I ssues Remain U nder D iscussion, 29 Sec. Reg. \& L. Rep. (BNA ), at 481, 492 (A pr. 11, 1997).

240. See 17 C.F.R. §§ 210.4-08, 229.305, 230.419, 240.17a-12 (1996).

241. See Fed A dopts Final Revisions to Capital Requirements for Derivatives $\mathrm{H}$ oldings, 27 Sec. R eg. \& L. R ep. (BNA ), at 1417, 1422 (Sept. 1, 1995).

242. See $\mathrm{H}$ azen, supra note 7 , at 989 (observing that derivatives are essentially futures and options); $\mathrm{H} \mathrm{u}, \mathrm{M}$ isunderstood D erivatives, supra note 7, at 1466-67 \& n.40 (same).

243. See Henry T.C. Hu, Swaps, the Modern Process of Financial Innovation and the Vulnerability of a Regulatory Paradigm, 138 U. PA . L. REV. 333, 346-53 (1989) (describing interest rate swaps); J erry W. M arkham, H ybrid Instruments, supra note 161, at 27-28 (same); R omano, supra note 7, at 46-68 (same). 
agreeing that if interest rates fall, $A$ will make payments to $B$, while if rates rise, $B$ will pay $A{ }^{244}$

A s this example shows, financial derivatives give parties an economic interest in an underlying financial instrument without requiring either side to actually deliver the instrument. In other words, OTC derivatives are off-exchange futures and options not intended to be settled by delivery-the modern equivalent of nineteenth-century "difference contracts." Banks, corporations, investment funds, and other end users who trade derivatives enter these agreements for the same reasons that traders once entered difference contracts. Thus, some end users employ derivatives to hedge against business risks from fluctuating interest rates and commodity prices, while others are driven by speculative passions. A recent survey of nonfinancial firms, for example, found that over $43 \%$ of those using derivatives reported having done so to "take a view" - or speculate- on the future direction of prices and interest rates. ${ }^{245}$

That observation raises the question of how a thriving OTC derivatives market can be reconciled with the pattern of legal hostility toward speculators described in Part I. In particular, how did a $\$ 70$ trillion OTC market manage to develop in the face of the CEA's ban on off-exchange futures? Historical accident may provide at least part of the answer. Organized futures and option trading has traditionally focused on such industrial and agricultural commodities as silver and porkbellies. ${ }^{246}$ In contrast, most OTC derivatives are agreements whose values are derived from financial instruments such as corporate equities and debt obligations. ${ }^{247} \mathrm{~A}$ Ithough it is easy with the benefit of hindsight to recognize financial derivatives as offexchange futures and options, when the market first grew to significant size in the 1980s, the CFTC initially appeared reluctant to assert jurisdiction over such unfamiliar arrangements. ${ }^{248}$ Thus it ignored

244. Swap agreements can also be based on currency exchange rates, commodity prices, or stock prices. See H u, M isunderstood D erivatives, supra note 7, at 1467.

245. Gordon M. B odnar et al., Wharton Survey of D erivatives U sage by U.S. N on-Financial Firms, 24 FIN. M GMT. 104, 106 (1995).

246. See R omano, supra note 7 , at 12 (noting that the first exchange-traded futures contract on a financial asset was introduced in 1975).

247. For example, one of the largest OTC markets is the market for interest rate swaps, instruments whose values are derived from debt obligations. See supra notes 243-44 and accompanying text (describing swaps).

248. See M arkham, Confederate B onds, supra note 161, at 18-19. 
some forms of financial derivatives entirely, ${ }^{249}$ while granting others (for example, swaps) administrative exemptions from the CE A. ${ }^{250}$

\section{$B$. The Controversy over A pplying the CEA to D erivatives}

The CFTC's initial reluctance to intervene in the derivatives market has since been replaced by a more aggressive regulatory stance. ${ }^{251}$ Spurred by continued explosive growth in derivatives trading and reports of spectacular losses suffered by speculating corporations and investment funds, ${ }^{252}$ the CFTC has begun to grapple more seriously with the question of whether and how to claim jurisdiction over the new market. Most dramatically, in May 1998 the CFTC issued an administrative release announcing its intention to undertake a "comprehensive regulatory reform effort" directed at OTC derivatives trading. ${ }^{253}$ The release makes clear the CFTC's position that the CEA applies to off-exchange derivatives trading. The release also notes the CFTC's concern about "problems and abuses" in the OTC market. ${ }^{254}$

The CFTC's release thus raises, for the first time, the prospect of significant government intervention in the hitherto largely unregulated derivatives market. Indeed, if the CEA is applied to financial derivatives, off-exchange trading in these instruments is presumptively illegal absent some express exemption. A s a result, the release has provoked a barrage of objections from the derivatives industry and from other federal agencies eager to stake their own jurisdic-

249. For example, it was only in 1985 that the CFTC established a Financial Products A dvisory Committee to advise it on financial derivatives. See $\mathrm{M}$ arkham, $\mathrm{H}$ ybrid Instruments, supra note 161 , at $40-41$.

250. In 1992, Congress amended the CEA to grant the CFTC express authority to exempt particular classes of transactions from regulation. See Futures Trading Practices A ct of 1992, Pub. L. N o. 102-546, 106 Stat. 3590 (codified at 7 U.S.C. § 6(c) (1994)). The CFTC subsequently exercised this power to exempt several important forms of financial derivatives from oversight, including swaps. See 17 C.F.R. § 35 (1998).

251. For example, in D unn v. CFTC, 519 U .S. 465 (1997), the CFTC claimed jurisdiction over the "interbank" market for trading in options based on foreign currencies. U Itimately, the Supreme Court rejected the CFTC's claim, citing the "Treasury A mendment" to the CEA, 7 U.S.C. § 2(ii) (1994), which states that the statute does not apply to transactions in foreign currencies. See D unn, 519 U .S. at 469.

252. See $M$ arkham, Confederate B onds, supra note 161 , at $28-31$ (listing numerous instances of derivatives losses); R omano, supra note 7, at 2-3 (same).

253. O ver-the-Counter D erivatives, 63 Fed. R eg. 26,114, 26,115 (1998) (to be codified at 17 C.F.R. pts. 34-35) (proposed M ay 12, 1998).

254. Id. at 26,115 . 
tional claims ${ }^{255}$ Congress has entered the fray by passing legislation that effectively blocks the CFTC from issuing any new regulations, pending the results of an investigation by a presidential working group that includes representatives from the Treasury, the Federal $R$ eserve, and the SEC, all of whom oppose the idea of CFTC regulation. ${ }^{256} \mathrm{M}$ eanwhile, legislators in the $\mathrm{H}$ ouse of $\mathrm{R}$ epresentatives have introduced legislation to expressly preclude the CFTC from regulating derivatives. ${ }^{257}$

F ederal lawmakers appear to have reached a critical juncture in the ongoing dispute over derivatives. A fter years of legal uncertainty, the question of whether and to what extent the CEA 's antispeculation provisions apply to derivatives may be about to be determined. The answer to that question carries vital economic implications. If the CFTC succeeds in its quest to regulate derivatives, it may find itself trying to stuff a multi-trillion dollar genie back into its bottle. A Ithough the CFTC's release clearly states that any new regulatory restrictions will apply only prospectively, ${ }^{258}$ it is difficult to imagine that the derivatives market could retain its current size if the CE A 's exchange trading requirement were applied to confine derivatives to the regulated exchanges. ${ }^{259} \mathrm{O}$ the other hand, if Congress exempts derivatives from the CEA, the result will be a radical departure from legal tradition. ${ }^{260}$ A s described in Part I, A merican common law has long refused to enforce off-exchange contracts of sale not intended to be settled by delivery of the good or service in question. ${ }^{261}$ Thus, in declaring derivatives exempt from the CEA, Congress would be overruling law that dates back not just decades, but centuries.

255. See Chair Introduces Bill, supra note 17, at 1197 (noting that the CFTC release has unsettled the market and provoked criticisms from the SE C, the Federal R eserve Board, and the Treasury, which claim that the CFTC lacks authority).

256. See D avid Barboza \& J eff G erth, Who's in Charge? A gency Infighting and Regulatory Uncertainty, N.Y. TIMES, Dec. 15, 1998, at C14 (discussing CFTC's proposal and Congress's response).

257. See Chair Introduces Bill, supra note 17, at 1197.

258. See $O$ ver-the-Counter D erivatives, 63 Fed. $R$ eg. at 26,116.

259. Thus some commentators have predicted that aggressive CFTC regulation of derivatives would undermine the domestic market and drive trading offshore. See, e.g., Tormey, supra note 9 , at 2358 .

260. The result would be the same if the CFTC takes the nominal position that the CEA applies to derivatives, but then declares derivatives exempt from regulation. See supra notes 15 , 250, and accompanying text (discussing the CFTC's exemptive authority); see also infra note 290 and accompanying text (same).

261. See supra notes $40-45$ and accompanying text. 
W hat is the best course? A Ithough derivatives raise a variety of policy issues, one of the most important is the derivatives market's effect on the level of speculative activity found in the $U$ nited States economy. D erivatives allow speculators to do an end run around the CEA 's exchange trading requirement by placing naked price wagers in the OTC market. They also allow traders to evade margin requirements, short sales restrictions, capital gains holding period requirements, and other rules that restrain speculation in spot markets. ${ }^{262}$ The risk hedging and information arbitrage models of trading imply that these opportunities for regulatory arbitrage may be a blessing rather than a bane. Thus commentators routinely praise derivatives for making it easier to shift risk and for increasing the accuracy of market prices, ${ }^{263}$ and attack the idea of CFTC regulation as an unnecessary obstacle to financial "innovation." 264

262. See, e.g., REVIEW OF FEDERAL MARGIN REGULATIONS, supra note 115, at 57-64 (describing margin requirements for exchange traded futures and options on futures, and noting that margin requirements range from a fraction of $1 \%$ to approximately $10 \%$ of a contract's value); D avid A. Weisbach, Should a Short Sale A gainst the B ox Be a Realization Event?, 50 NA T'L TAX J . 495, 495-96 (1997) (discussing how equity swaps can be used to avoid capital gains holding requirements); W orley, supra note 121, at 1293-98 (describing how bearish stock speculators can avoid the SE C's short sale restrictions by shorting stock index futures and options).

263. See, e.g., $\mathrm{H}$ azen, supra note 7, at 1008 (observing that financial derivatives are commonly praised for shifting risk and promoting better pricing); $\mathrm{H} \mathrm{u}, \mathrm{M}$ isunderstood D erivatives, supra note 7, at 1466 (arguing that derivatives can be valuable for hedging risks); R omano, supra note 7, at 5 (stating that derivatives "serve important economic functions that cannot be overemphasized," including risk hedging and price discovery); Stein, supra note 69, at 498 (describing how derivatives have been praised for contributing to the efficiency of markets). B ut see $\mathrm{H} \mathrm{u}, \mathrm{M}$ isunderstood D erivatives, supra note 7, at $1466 \mathrm{n.35}$ ("It is important not to exaggerate the private benefit of being able to hedge against such market risks.").

264. See, e.g., Hu, Misunderstood Derivatives, supra note 7, at 1513 (warning against "Procrustean" regulation of derivatives that hampers financial innovation); M arkham, Confederate B onds, supra note 161, at 72 (contending that regulating OTC derivatives under the CEA "may be too intrusive, resulting in a strangling of this economically useful, highly innovative, and still growing industry"); M arkham, $\mathrm{H}$ ybrid Instruments, supra note 161, at 2, 53 (arguing that CFTC regulations would "hamper innovation" and result in lost market opportunities); M erton H. M iller \& Christopher L. Culp, The SE C's Costly D isclosure Rules, W A LL ST. J ., J une 15,1996 , at A 14 (criticizing as "worse than worthless" a proposed SE C rule that would require public companies using derivatives to disclose estimates of their exposures to market risk). But cf. $\mathrm{H}$ azen, supra note 7, at 1031 (maintaining that derivatives should be subject to an economic purpose test similar to that imposed by the CFTC on the exchanges).

Indeed, the idea that speculation in futures and options necessarily serves economic efficiency has begun to threaten the CFTC's authority to police against speculative trading on the regulated exchanges as well. Commentators have begun to attack the wisdom of the CEA by arguing that restrictions on futures and options trading, whether on or off the exchanges, only impede progress and financial innovation. See John $\mathrm{H}$. Stassen, Propaganda as Positive L aw: Section 3 of the Commodity Exchange Act ( $\mathrm{A}$ Case Study of $\mathrm{H}$ ow Economic Facts $\mathrm{Can} \mathrm{Be}$ 
To the observer familiar with the heterogeneous expectations model of trading and its implications, however, the sudden appearance of an immense speculative market seems a more ominous development. Thus the next Section considers how the $\mathrm{HE}$ approach can offer insights to regulators seeking to understanding the economic consequences of derivatives trading.

\section{HE Theory and the E conomic Consequences of D erivatives Speculation}

W hen Congress passed the CE A in 1936, its members firmly believed that speculators harm markets. ${ }^{265}$ O bservers familiar with the risk hedging and information arbitrage models of trading may find the notion that speculation can be harmful unattractively oldfashioned. Thus contemporary scholars and policymakers tend to downplay the CEA's antispeculation origins, ${ }^{266}$ emphasizing instead the CEA 's role in preventing fraud and manipulation in futures and options trading. ${ }^{267}$ Similarly, the principal danger regulators now as-

Changed By Act of Congress), 58 CHI.-KENT L. REV. 635, 655 (1982) (attacking as "economically unsound" the CEA 's premise that speculation can be excessive); Stein, supra note 69, at 473 (noting that the exchange trading requirement which is the CEA 's central purpose "recently has been attacked as unworkable and undesirable" because it discourages useful transactions).

The organized exchanges, complaining of a competitive disadvantage relative to the unregulated OTC market, have adopted these arguments to push for a professional market, or "ProM arket," exemption from the CEA that would apply to all exchange-based trading between parties with net worths of at least \$1 million. See S. 257, 105th Cong. § 6 (1997); H.R . 467, 105th Cong. $\$ 102$ (1997). A lthough $\$ 1$ million may seem a significant figure, an exemption set at this level would apply to virtually all corporations, banks, pension funds, and other institutional traders, as well as to many individuals. The CFTC has estimated that the net result would be to remove $90 \%$ of exchange trading volume from CFTC oversight. See Exchanges' Self-Interest Would Prevail Under ProM arket Proposal, B orn Warns, 29 Sec. Reg. \& L. Rep. (BNA ), at 621 (M ay 2, 1997) (reporting the remarks of CFTC Chairman B rooksley B orn).

265. See supra note 87 and accompanying text. Indeed, stripped of its original antispeculation purpose, much of the CEA no longer makes sense. Why require exchange-traded futures to serve an economic purpose beyond "mere speculation," for example, if speculation itself serves an economic purpose?

266. O ther antispeculation doctrines have been subject to similar treatment. Thus, for example, modern commentators now generally explain the insurance doctrines of indemnity and insurable interest as responses to problems of moral hazard, see supra text accompanying notes 105-08, and justify the capital gains holding period requirement on non-antispeculative grounds, see supra notes 137-39 and accompanying text.

267. See, e.g., D unn v. CFTC, 519 U .S. 465, 474-75 (1997) (noting the CFTC's claim that it should have jurisdiction over currency derivatives to prevent fraud); $M$ arkham, $M$ anipulation, supra note 218, at 282-83 (1991) (suggesting that the CFTC was created to prevent manipulation); Perdue, supra note 218, at 345 (emphasizing the CFTC's antimanipulation purpose). This revisionist view paints the $\mathrm{CEA}$ as a technical and somewhat trivial consumer protection stat- 
sociate with derivatives is not excessive speculation but the perceived peril of "systemic" risk - the possibility that cataclysmic derivatives losses at one firm might trigger a chain reaction of crises at other firms. ${ }^{268}$

The HE model of speculation suggests, however, that the modern assumption that speculation is efficient may be dangerously misleading when applied to derivatives trading. The analysis provided in Part III implies that HE trading can lead to three distinct forms of economic harm. First, speculation driven by subjective disagreement can reduce social welfare by eroding trader wealth through transaction costs without providing any compensating benefit; second, speculation can reduce social welfare by increasing traders' risk, and with it the level of risk found in the marketplace; and third, speculation can in some circumstances lead to price distortions and market bubbles. ${ }^{269}$ L et us consider how each form of harm might apply in the case of speculation in OTC derivatives.

Focusing first on derivatives speculation's effects on trader wealth, it is important to recognize that corporations and investment funds that attempt to earn trading profits by speculating in derivatives must incur a number of expenses. These include the time and effort necessary to make market predictions, as well as the fees and spreads charged by derivatives dealers. It is difficult to estimate how much is spent annually on costs associated with OTC derivatives trading. However, assuming (extremely conservatively) that transaction costs average only a tenth of a percent of notional amount, ${ }^{270} \mathrm{a}$ $\$ 70$ trillion OTC market implies transaction costs of approximately $\$ 70$ billion. If $\mathrm{HE}$ trading is common in the OTC market, much if not most of that $\$ 70$ billion has been squandered in the zero-sum game of trying to outpredict other $\mathrm{HE}$ speculators.

A $n$ even more important source of trader welfare losses from OTC derivatives trading may take the form of increased and uncompensated trader risk. The $\mathrm{HE}$ model predicts that the opportunity to

ute, of interest only to the small subgroup of the population that trades on the organized futures exchanges.

268. See GAO REPORT, supra note 11 , at 7-8 (discussing systemic risk). R ather than supporting the role of the CFTC, a focus on systemic risk emphasizes the importance of the Federal R eserve's monitoring of minimum capital requirements and oversight of reporting systems. See id. at 14-16 (listing G A O's recommendations regarding derivatives, which do not mention the (FTC).

269. See supra Part III.B.

270. See Hu, Hedging Expectations, supra note 7, at $1014 \mathrm{n} .132$ (describing dealers' relatively low spreads on simple swaps as ranging from $0.12 \%$ to $0.22 \%$ ). 
speculate in OTC derivatives can tempt end users into volatile markets they would otherwise choose to avoid. Thus Procter \& Gamble and $\mathrm{G}$ ibson $\mathrm{G}$ reetings, normally in the staid businesses of hawking shampoo and greeting cards, lost hundreds of millions of dollars speculating on interest rates in the swaps market. ${ }^{271} \mathrm{~A} n$ even more compelling example may be found in the recent near collapse of the hedge fund Long-Term Capital Management L.P. ${ }^{272}$ Because the managers of L ong-Term Capital believed that they could predict future patterns of price volatility in financial markets, they not only risked their investors' money to place derivatives bets, they also borrowed money to increase the size of the bets. A t one point, the firm held derivatives positions approximately 100 times larger than its capital base. $^{273}$

By suggesting how the opportunity to speculate cheaply through derivatives may tempt traders into accepting uncompensated risks, the HE model of speculation accordingly offers to solve an important theoretical puzzle: the perceived link between derivatives trading and increased systemic risk. Even before the collapse of B arings Bank and the near collapse of Long-Term Capital, policymakers feared that derivatives trading losses might drive one or more large financial institutions into bankruptcy, triggering a chain reaction of other firm failures. ${ }^{274}$ This link between derivatives and increased systemic risk is difficult to explain under the conventional risk hedging model of trading. A fter all, if derivatives are used primarily for hedging, they should reduce systemic risk by reducing the risks of the individual firms that make up the system. ${ }^{275}$ In contrast, the HE model explains how derivatives trading can increase systemic risk by increasing both

271. See sources cited supra note 27 (describing these and other swaps market losses); see also Henry T.C. Hu, Derivatives and Unexpected Risks: An Introduction, 21 J. CORP. L. 1 (1995) (observing that corporate derivatives "end-users, intentionally or not, sometimes entered derivative realities that involved more, rather than less, fearsome market risks").

272. See generally Steven Lipin et al., B ailout B lues: H ow a Big H edge Fund M arketed Its Expertise and Shrouded Its Risks, W A LL St. J ., Sept. 25, 1998, at A 1 (discussing the near-collapse of L ong-Term Capital).

273. See id.

274. See GAO REPORT, supra note 11 , at 7-8 (associating derivatives with increased systemic risk). The recent near failure of Long-Term Capital has reinforced this perception that derivatives increase risk. See, e.g., David Barboza \& J eff G erth, On Regulating D erivatives: L ong-Term Capital Bailout Prompts Call for Action, N.Y. TIMES, D ec. 15, 1998, at C1 ("'Y ou have huge risks building up on the shoulders of these few huge financial institutions." ) (quoting statement by Henry T.C. H u).

275. Cf. supra text accompanying note 152 (discussing information arbitrageurs' techniques for reaping profits without taking on increased risk). 
the number of firms that expose themselves to risk and the level of their exposure.

The discussion above suggests that $\mathrm{HE}$ speculation in derivatives clearly carries the potential to reduce social welfare by eroding traders' wealth while increasing the risks they face. A s for the third form of harm often associated with speculative trading-allocative inefficiency due to market bubbles and similar price distortions-the analysis provided in Part III is more equivocal. ${ }^{276}$ B ecause derivatives are essentially off-exchange futures and options, the existence of a thriving derivatives market can significantly reduce obstacles to short selling. Thus, in some cases, opening a derivatives market may improve the accuracy of market prices by eliminating the price-inflating effects of short sales restrictions in the spot market for the underlying commodity or financial instrument. This analysis implies that derivatives can encourage more accurate market prices through a mechanism quite different from that suggested by the information arbitrage model, suggesting a hitherto unrecognized social benefit from derivatives trading. A the same time, if opening a derivatives market increases the absolute dispersion of traders' opinions by increasing the total pool of speculators, and if some restrictions on short sales remain, the net result may be more bubbles. ${ }^{277} \mathrm{An} \mathrm{HE}$ analysis of derivatives speculation accordingly predicts that derivatives trading has the potential to improve the accuracy of market prices in some circumstances, and to distort prices in others.

A more sophisticated analysis of the derivatives market that incorporates the lessons of the $\mathrm{HE}$ model consequently offers the unsettling prediction that derivatives trading can be the source of efficiency losses as well as efficiency gains. That possibility carries important implications for public policy. Thus far, policymakers have been unable to resolve the conflict between economic theory's claim that derivatives speculation promotes efficiency and the strong intuition that something is amiss when a large portion of the nation's energy and resources is devoted to speculative activity. As a result, lawmakers have adopted a largely hands-off approach toward OTC derivatives trading.

276. See supra notes $230-33$ and accompanying text.

277. Moreover, encouraging speculation in derivatives runs the risk of increasing traders' welfare losses due to transaction costs and increased risk exposure. See supra notes 174-76 and accompanying text. 
The HE model suggests, however, that in some circumstances unrestrained speculation may indeed pose a threat to social welfare. A dding the insights of the $\mathrm{HE}$ approach to those of the risk hedging and information arbitrage theories thus clarifies the fundamental economic problem posed by OTC derivatives. Put simply, that problem is: how can we protect beneficial forms of derivatives trading while discouraging welfare-reducing, price-distorting transactions? A full discussion of the many policy issues posed by derivatives and the optimal regulatory response lies beyond the scope of this A rticle. The $\mathrm{HE}$ model suggests some interesting potential directions for exploration, however. In particular, two traditional antispeculation rulesthe CEA and its common law precursor, the rule against difference contracts-may offer useful lessons for lawmakers seeking to constrain destructive forms of derivatives speculation. Thus the next Section considers how lawmakers might go about trying to maximize the social benefits of derivatives while minimizing their social costs.

\section{D iscouraging HE Trading in D erivatives: L essons from the CE A}

The challenge of filtering out welfare-reducing speculation while protecting economically beneficial transactions exists in any speculative market, and is not unique to OTC derivatives. Policymakers accordingly can look to existing antispeculation laws for strategies to temper welfare-reducing speculation in derivatives. O ne obvious prototype for regulation is the CEA.

A s discussed in Part I, the CEA's ban on off-exchange futures can be viewed as a codification of the common law ban on difference contracts. ${ }^{278}$ In addition to the exchange trading requirement, however, the CEA includes other provisions that significantly modify the common law. ${ }^{279}$ In particular, the common law placed no restrictions on the kinds of contracts that could be traded on the organized exchanges, choosing instead to leave those decisions to the exchanges and their members. In contrast, the CEA created a government en-

278. See supra text accompanying notes 88-91.

279. For example, the CEA authorizes the CFTC to police against fraud and manipulation in futures trading, see sources cited supra note 218 (discussing the CEA's antimanipulation function), allows the imposition of trading and position limits on individual traders, see supra note 95 and accompanying text (discussing position and trading limits), and imposes criminal penalties for off-exchange trading, see supra note 92 and accompanying text (discussing criminal penalties). 
tity to act as an antispeculative filter: the Commodity Futures Trading Commission. ${ }^{280}$

The CFTC filters out speculation in futures and options on at least three levels. First, the CFTC discourages speculation in exchange-listed contracts at the level of individual transactions, by imposing position limits and trading limits that are not applied to trades that serve a "bona fide" hedging purpose. ${ }^{281}$ Second, the CFTC serves as a gatekeeper to the exchanges by deciding what sorts of standardized contracts may be listed for trading in the first place. This judgment revolves, in part, around whether a particular contract can be shown to serve an economic purpose beyond "mere speculation." ${ }^{282}$ Third, the CFTC has the authority to approve off-exchange trading in certain classes of instruments by granting administrative exemptions to the CE A . B efore its M ay 1998 release, the CFTC used this authority to exempt several important classes of financial derivatives from oversight, including swaps and hybrids. ${ }^{283}$

The CFTC accordingly enjoys considerable authority to ban or otherwise limit transactions it does not believe to be economically useful. Thus, one possible strategy for discouraging disagreementbased speculation in financial derivatives would be to affirm the CFTC's claim that the CEA applies to OTC derivatives trading. This approach would treat financial derivatives agreements as illegal unless the CFTC either approved a particular type of contract for trading on a regulated futures exchange, or granted that type of contract an administrative exemption from the CEA. ${ }^{284}$ Derivatives users would accordingly be required to demonstrate to the CFTC's satisfaction on a contract-by-contract ${ }^{285}$ basis that their trading served some beneficial economic purpose.

Some observers might object to this approach on the ground that it is too difficult for the CFTC to distinguish between useful risk

280. See supra note 85 and accompanying text.

281. See supra notes $94-95$ and accompanying text.

282. See supra note 94 and accompanying text.

283. See O ver-the-Counter D erivatives, 63 Fed. R eg. 26,114, 26,116 (1998) (to be codified at 17 C.F.R. pts. 34-35) (proposed May 12, 1998) (discussing the CFTC's decision to exempt swaps from regulation); see also supra note 250 and accompanying text (same).

284. Indeed, Congress could go further and statutorily reverse the Supreme Court's decision in Dunn v. CFTC, 519 U .S. 465 (1997), by enacting legislation declaring that the CEA's Treasury A mendment does not exempt trading in currency-based derivatives. See supra note 251 (discussing D unn and the Treasury A mendment).

285. Or even, in the case of trading limits and position limits, transaction-by-transaction. 
hedging and information arbitrage trades on the one hand, and wasteful disagreement-based transactions on the other. W hile no perfect means of accurately identifying the nature of individual transactions may exist, there are a number of ways the CFTC can crudely distinguish beneficial from harmful trading. For example, just as the CFTC now allows traders in exchange-listed futures to escape position limits and trading limits by demonstrating a hedging purpose, the CFTC might require traders who want to list a particular type of derivatives contract for trading on an exchange to demonstrate that the contract offsets a preexisting source of risk. Similarly, if the CFTC finds that the market for a particular futures contract appears dominated almost entirely by profit-seeking speculators rather than consumers and producers, or that speculators as a class seem to be losing money trading in the contract, it might reasonably conclude that the contract appeals primarily to $\mathrm{HE}$ traders rather than true information arbitrageurs. $^{286}$

To a generation of legal scholars raised on interest group theory, this notion of the CFTC as a bureaucratic gatekeeper to the derivatives market may seem unattractive. ${ }^{287} \mathrm{H}$ istory suggests, however, that the CFTC has served as a relatively faithful antispeculation watchdog. In the U nited States, most speculative disasters have occurred outside the regulated exchanges. O range County, Procter $\&$ G amble, and $G$ ibson $G$ reetings all suffered their losses while trading in the OTC market. ${ }^{288}$ In contrast, the lax regulation characteristic of many foreign futures exchanges has produced such high-profile catastrophes as those of Barings Bank and Sumitomo Bank, which both lost billions of dollars speculating in standardized contracts on organized foreign futures exchanges. ${ }^{289}$

286. See supra text accompanying notes 171-76 (describing $\mathrm{HE}$ trading as characterized by speculator-with-speculator trading and ex post speculator losses).

287. For example, R oberta R omano has argued that the CEA can best be explained not as a good faith legislative attempt to serve the public interest by discouraging welfare-reducing speculation, but as the possibly inefficient product of a legislative process in which an organized and self-interested coalition of commodities producers, banks, and organized futures exchanges has managed to control the regulatory outcome. See R oberta R omano, The Political D ynamics of D erivative Securities Regulation, 14 Y A LE J. on RE G. 279, 314-17 (1997).

288. See sources cited supra note 27 (describing losses).

289. See Coming a Cropper in Copper, THE E CONOMIST, J une 22, 1996, at 69 (noting that Sumitomo's losses resulted from trading copper futures and options on the London M etal Exchange); Stephen E. Frank, J.P. M organ Reprimanded on Sumitomo, W A L L ST. J ., A pr. 3, 1997, at A 3 (reporting that Sumitomo's losses totaled $\$ 2.6$ billion); R ichard L. H olman, World Wire, W A LL ST. J ., J une 12, 1997, at A 12 (reporting that B arings Bank's losses totaled $\$ 1.36$ billion); Sara Webb et al., A Royal M ess: Britain's Barings PL C B ets on Derivatives, W A LL ST. J ., Feb. 
$Y$ et applying the CEA in its present form to OTC derivatives inevitably raises the possibility that CFTC oversight designed to deter welfare-reducing speculation may also deter beneficial trading. U nlike the standardized contracts traditionally traded on the organized exchanges, OTC derivatives are privately negotiated, often highly customized instruments that can take a virtually infinite number of forms. A s a result, applying the CEA to derivatives might require many users to seek the CFTC's prior approval for each and every contract they enter, which might prove an insurmountable obstacle to many beneficial transactions. Y et, if the CFTC uses its authority to declare a broad class of derivatives exempt from the CEA, it has effectively abandoned any attempt to discourage $\mathrm{HE}$ speculation in the exempt instruments.

\section{E. D iscouraging H E Trading in D erivatives: L essons from the Common Law}

That observation sets the stage for exploring an alternative to the apparently binary choice now faced by federal regulators of either allowing the CFTC to substantively regulate OTC derivatives, or exempting them from the CEA entirely. The alternative is to apply the CEA to derivatives, while amending the statute to eliminate the CEA provisions that criminalize off-exchange futures and options trading. ${ }^{290}$ Such an amendment would effectively return us to the common law rule, under which difference contracts that were not entered on an organized exchange and that could not be shown to serve a hedging purpose were regarded as unenforceable- but not criminal-transactions.

U nder the common law, traders were free to enter off-exchange difference agreements that did not serve an indemnity (hedging) purpose. ${ }^{291} \mathrm{H}$ owever, because such agreements were legally unenforceable, traders had to find private mechanisms to enforce them. Legal scholars recently have shown a keen interest in situations where market participants choose to settle their disagreements through private enforcement mechanisms, rather than by going to court and invoking the coercive powers of the state. ${ }^{292}$ M ost discussions of such private

27, 1995, at A 1 (noting that B arings incurred its losses trading stock-index futures contracts on the $O$ saka and Singapore International M onetary exchanges).

290. See 7 U .S.C. § 13 (1994); see also supra note 92 and accompanying text.

291. See supra notes $38-42$ and accompanying text.

292. See, e.g., Robert C. Ellickson, Order Without law: How Neighbors Settle DISPUTES (1991) (arguing that people can often settle disputes without referring to any source 
ordering have focused, however, on cases where parties voluntarily avoid the legal system. The heterogeneous expectations model of speculation offers an interesting variation on this theme by suggesting how private ordering can be superior to government coercion not only when parties voluntarily opt out of the legal system, but also, sometimes, when they are involuntarily shut out.

To see how a rule of civil unenforceability may provide a superior solution to the problem of welfare-reducing speculation in OTC derivatives, consider how the parties to an OTC agreement might find ways of assuring performance other than judicial enforcement. M ost obviously, in situations where parties deal repeatedly with each other or with others in the same business community, one of the best ways to assure performance is through reputation. Because a good reputation-that is, a reputation for fulfilling contractual obligations- can induce others to trade, the desire to preserve reputational capital protects against opportunistic defaults in legally void agreements. ${ }^{293}$ For example, the swaps market is dominated by large banks, and reputation is regarded as such a reliable guarantee of performance that even very large trades are often put into writing only after a transaction has actually occurred. ${ }^{294}$ This analysis suggests that when a corporation, bank, or investment fund expects to be using OTC derivatives on an ongoing basis, it will be reluctant to renege on a legally unenforceable agreement for fear that it will be excluded from participating in the OTC derivatives market in the future.

In an OTC derivatives market characterized by a mix of hedging, information arbitrage, and HE trading, which sorts of traders are likely to be repeat players with strong reputational interests in keeping their promises? Let us return to the phenomena of ex post speculator losses and trader learning discussed in Part III. ${ }^{295}$ Informa-

of law); L isa B ernstein, O pting O ut of the L egal System: Extralegal Contractual R elations in the Diamond Industry, 21 J. LEGA L STUD. 115 (1992) (analyzing the elaborate rules by which diamond industry participants resolve disputes without reference to state-created law). See generally Symposium, L aw, E conomics, \& N orms, 144 U . PA . L. R E V . 1643 (1996).

293. See Bernstein, supra note 292, at 131-32 (discussing reputation as an enforcement mechanism). When contracts are legally unenforceable, contracting parties can also try to reduce the chance of opportunistic breach through such measures as mutual incremental performance or posting a bond. Neither seems particularly useful in the context of OTC derivatives, however. Given the size of most derivatives deals, posting a bond is likely to prove prohibitively expensive, while incremental performance no longer works when prices or interest rates shift to the point that one party incurs a significant trading loss.

294. Clair A. Hill, Order In The Shadow of the Law, or How Contracts Do Things With Words $10 \mathrm{n} .18$ (1998) (unpublished manuscript on file with author).

295. See supra notes 190-94 and accompanying text. 
tion arbitrageurs, and risk-accepting speculators who deal with hedgers, generally enjoy ex post the trading profits they expected ex ante. Thus arbitrageurs and risk-accepting speculators are likely to become repeat players with strong interests in protecting their reputations for keeping promises, even when a particular trade is no longer advantageous. ${ }^{296} \mathrm{HE}$ speculators, in contrast, on average incur losses from trading, and eventually stop. Thus HE traders are far more likely to be amateurs who will renege opportunistically on a derivatives agreement if a deal turns against them. A s an example, consider what happened when $\mathrm{G}$ ibson $\mathrm{G}$ reetings, Procter $\&$ Gamble, and O range County suffered derivatives trading losses. A II three were relative newcomers to the derivatives market whose trades were driven by the speculative desire to reap profits by predicting interest rates, ${ }^{297}$ and all three responded to their trading losses by filing lawsuits challenging the enforceability of their agreements. ${ }^{298}$

Declaring OTC derivatives unenforceable but not illegal accordingly may discourage $\mathrm{HE}$ speculation while allowing risk hedging and information arbitrage trading. If the individuals and institutions who deal in derivatives know they cannot go to court to enforce their agreements, trading will tend to take place only among those with large reputational stakes- that is, among repeat players whose trading not only appears beneficial ex ante, but actually results in ex post benefits. A mateurs will be able to find willing counterparties only if they can demonstrate that their derivatives contracts are actually enforceable "indemnity" agreements that hedge against demonstrable risks, or, perhaps, that they are information arbitrageurs or riskaccepting speculators with histories of profitable dealings in other markets who are likely to become repeat players in derivatives. ${ }^{299}$

296. E ven under a rule of civil unenforceability, risk-accepting speculators would be able to enforce their derivatives agreements in the courts if they could prove that their counterparties were using their agreements to offset preexisting sources of business risk. See supra notes 65-67 and accompanying text (discussing the enforceability of indemnity agreements).

297. See sources cited supra note 27 (describing cases).

298. See Procter \& G amble Co. v. B ankers Trust Co., 925 F. Supp. 1270 (S.D. O hio 1996); $\mathrm{K}$ necht, supra note 27, at $\mathrm{A} 3$ (discussing the O range County suit); Paulette Thomas, Procter \& G amble Sues B ankers Trust B ecause of H uge L osses on D erivatives, W A LL ST. J ., O ct. 28, 1994, at $A 6$ (discussing Procter \& G amble suit); R ichard Walters, B ankers Trust Sued over U.S. D erivatives Contracts, FIN. TIMES, Sept. 14, 1994, at 27 (discussing G ibson G reetings's claim that Bankers Trust "did not reveal the material risks and misrepresented the nature of the transactions and thereby deceived and defrauded" the company).

299. M oreover, if derivatives are legally unenforceable, both parties to the transaction may have an incentive to share information regarding their estimates of future risks and returns, in an attempt to ensure that neither will renege later. Such sharing may itself discourage $\mathrm{HE}$ 
Thus, by modifying the CEA to make off-exchange futures and options unenforceable in the courts, lawmakers can encourage private ordering that may be more effective than government regulation in filtering out speculation from the OTC market.

Indeed, to some extent this may be the system of "regulation" currently in place, albeit by default rather than by design. When trading in financial derivatives first became commonplace in the early 1980s, many traders seemed to presume that derivatives, like other contracts, were legally enforceable. B y the late 1980s and early 1990s, however, a series of well-publicized losses suffered by speculating individuals, corporations, and investment funds produced a number of lawsuits filed by disappointed derivatives users that challenged the validity of their agreements on grounds ranging from antibucketshop laws, to the CEA, to old-fashioned fraud..$^{300}$ A dditional questions have been raised by the CFTC's recent eagerness to claim jurisdiction over the OTC market, and especially by its M ay 1998 concept release announcing its intent to consider comprehensive regulation. ${ }^{301}$ The net result has been to cast a cloud of legal uncertainty over the OTC market. ${ }^{302}$

speculation by encouraging derivatives traders to form more homogenous expectations. This result compares favorably with the incentives to mislead that exist when derivatives contracts are legally enforceable. For example, one prominent derivatives dealer, Banker's Trust, has been accused in several recent lawsuits of misleading its clients about the risks associated with the derivatives it sold them. See, e.g., Procter \& G amble, 925 F. Supp. 1270; Thomas, supra note 298, at A 6 (discussing the Procter \& Gamble suit); Walters, supra note 298, at 27 (discussing $\mathrm{G}$ ibson $\mathrm{G}$ reetings's claim)

300. See, e.g., CFTC v. Noble M etals Int'I, Inc., 67 F.3d 766 (9th Cir. 1995) (alleging violations of the CEA ); Salomon Forex, Inc. v. Tauber, 8 F.3d 966 (4th Cir. 1993) (alleging violations of the CEA and antibucketshop laws); U nited States v. B entley, 825 F.2d 1104 (7th Cir. 1987) (alleging violations of mail and wire fraud statutes); Thomas, supra note 298, at A 6 (discussing suit alleging fraud and deception); W alters, supra note 298, at 27 (discussing G ibson G reetings's claims of misrepresentation); Transnor (Bermuda) Ltd. v. B P N orth A m. Petrol., 738 F. Supp. 1472 (S.D.N.Y . 1990) (alleging manipulation in derivatives transaction).

301. O ver-the-Counter D erivatives, 63 Fed. R eg. 26,114 (1998) (to be codified at 17 C.F.R . pts. 34-35) (proposed M ay 12, 1998); see also sources listed supra note 17 (reporting on the adverse reaction to the release).

302. See A Iton B. H arris, The CFTC and D erivative Products: Purposeful A mbiguity and J urisdictional Reach, 71 CHI.-KENT L. REV. 1117, 1167 (1996) (stating that "'court rulings . . . conspired to keep OTC derivatives under a cloud of legal uncertainty,' and that the CFTC, in order 'to avoid disrupting the new OTC derivatives markets,' was forced to issue 'ever more tortured interpretations of the [CEA ]'") (quoting M ary L. Shapiro, Chairman, CFTC, A ddress B efore the National A ss' $n$ of Business E conomists (Feb. 15, 1995)) (alterations in original) (emphasis omitted); Q uestion of Who Will R egulate OTC M arket H as B een Raised, CFTC O fficial Suggests, 30 Sec. R eg. \& L. Rep. (BNA), at 1198 (A ug. 7, 1998) (noting continuing legal uncertainty over whether swaps must be traded on an exchange). 
D erivatives trading nevertheless continues to flourish. The surprising resiliency of the OTC market suggests a provocative interpretation of recent events. Following such well-publicized losses as those of O range County, G ibson G reetings, and Procter \& G amble in 1994, recent years have seen comparatively few speculative disasters in the OTC market. This may be due to relatively stable prices and interest rates in the macroeconomy, which have decreased the odds that a derivatives deal will produce great losses or great gains. It is also possible, however, that legal uncertainty about whether derivatives are enforceable has made traders hesitate to do business with counterparties that they think might renege on a deal that goes sour. A Ithough it is perhaps premature to judge the aftermath of the L ongTerm Capital debacle, it offers an interesting contrast to earlier derivatives disasters. U nlike Procter $\&$ Gamble, G ibson $G$ reetings, and Orange County-which all have some primary business purpose other than derivatives trading-Long-Term Capital is a hedge fund that was expressly created to reap profits by trading derivatives. ${ }^{303}$ Thus, its managers are arguably information arbitrageurs with a longterm reputational interest in the OTC market. A nd rather than renege on its derivatives contracts, L ong-Term Capital has responded thus far by seeking additional funding to permit it to perform its agreements. $^{304}$

These observations suggest that the ongoing legal uncertainty over the enforceability of OTC derivatives contracts may have weeded at least some HE speculators out of the contemporary derivatives market. If so, policymakers debating how to respond to the CFTC's claim of jurisdiction over the derivatives market might do well to recognize that if the Congress responds to the CFTC's initiative by exempting OTC derivatives from the CEA, it will have done more than adopt a laissez faire attitude of nonintervention. In effect, it will have chosen to sanction derivatives trading by offering to enforce derivatives contracts in the courts. In doing so, it will have abandoned a legal tradition of unenforceability that dates back not just decades, but centuries. ${ }^{305}$

303. See B arboza \& G erth, supra note 274 , at C1.

304. See Raghavan \& Pacelle, supra note 27, at A 1 (describing Long-Term Capital's response to its derivatives losses).

305. This analysis presumes that if Congress passes legislation to exempt OTC derivatives from the CEA , that legislation will be deemed by the courts to have preempted state law in the area. If not, the interesting possibility arises that federal legislation exempting derivatives from 
Is such a dramatic change in the law wise? Making derivatives contracts legally enforceable may make sense when trading provides economic benefits by efficiently shifting risk or improving market prices. Thus, for example, society may want to enforce exchangetraded contracts that the CFTC has determined serve a useful economic purpose-for example, commodities futures that serve consumers' and producers' hedging needs, or stock futures and options that ward off speculative price bubbles by reducing obstacles to short selling. In many cases of HE trading, however, enforceability may encourage transactions that decrease rather than increase social welfare. Thus, rather than declare OTC derivatives exempt under the $C E A$, Congress might do better to amend the CEA to return to the common law rule that off-exchange futures and options not settled by delivery are legally unenforceable unless shown to serve a hedging purpose.

G iven the legal uncertainty that already exists in the OTC market, this approach would not so much create a new rule of civil unenforceability, as preserve and clarify the source of the unenforceability that exists today. In doing so, it may also preserve the private ordering that may already be policing against destructive $\mathrm{HE}$ speculation in the OTC market.

\section{F. Summary: R egulation and Private O rdering in the M arket for OTC D erivatives}

OTC derivatives can be used to hedge against business risks and to profit from superior price information. They can also be used, however, to speculate on subjective disagreement over the future. D espite the apparent difficulty of distinguishing disagreement-driven transactions from other forms of trading, lawmakers seeking to reduce the welfare losses that can result from $\mathrm{HE}$ speculation in derivatives can choose from a variety of regulatory strategies. ${ }^{306}$ O ne prom-

the CEA will resurrect the common law rule by leading courts to declare that federal law no longer preempts state law regulating difference contract trading.

306. In addition to the government gatekeeper and private ordering strategies examined in this A rticle, there are other ways lawmakers can discourage $\mathrm{HE}$ trading. For example, federal securities law identifies categories of transactions that seem likely to appeal primarily to $\mathrm{HE}$ speculators, and then discourages or prohibits those categories entirely. See supra notes 118-28 and accompanying text (discussing margin requirements, short sales restrictions, and the uptick rule). This strategy is evident in other antispeculation doctrines as well. The capital gains holding period requirement discourages the sale of any capital asset that has been held for less than one year, see supra notes 137-39 and accompanying text, while the champerty doctrine flatly forbids the sale of legal claims, see supra note 136 and accompanying text. In addition to 
ising approach might be to return to the common law rule by decriminalizing trading in futures and options contracts outside the CFTC-regulated exchanges, ${ }^{307}$ while declaring such contracts to be legally unenforceable.

A rule of civil unenforceability that encourages private ordering may offer significant advantages as a means of filtering out $\mathrm{HE}$ speculation while preserving more beneficial transactions. This is not to suggest that the common law rule provides a perfect solution: although judges can easily distinguish enforceable exchange-traded futures from OTC transactions, applying the indemnity exception for true hedging contracts is more difficult, and almost any approach courts can devise to apply the common law rule will likely allow some welfare-reducing trading to occur and discourage some efficient transactions. Nevertheless, as a result of the CFTC's M ay 1998 release, it appears that legal uncertainty about OTC derivatives' status under the CEA is about to be resolved one way or the other. The heterogeneous expectations model of speculation suggests that a return to the common law rule that encourages private ordering may be an attractive alternative to "reforms" that would either require all derivatives users to do business under the CFTC's watchful eye and the threat of criminal sanction, or abandon the centuries-old tradition of legal restraints on speculation by declaring OTC derivatives exempt from the CE A and therefore enforceable in the courts.

\section{CONCLUSION}

Contemporary scholars and policymakers frequently assert that speculation-whether in stocks, real estate, or OTC derivativesserves a valuable economic function. This claim is grounded in modern economic theory and particularly in the risk hedging and infor-

categorically restricting some kinds of trading, the SE A also employs a second and more subtle strategy for discouraging disagreement-based stock speculation: mandatory disclosure rules that promote homogenous expectations by providing uniform, subsidized information to investors. This suggests an alternative rationale for mandatory disclosure that has been largely overlooked by contemporary legal scholars. But see Stout, Casinos, supra note 132, at 695-97 (arguing that mandatory disclosure may serve an antispeculation function). Finally, the observation that $\mathrm{HE}$ traders tend to be amateurs suggests that $\mathrm{HE}$ speculation can be reduced in some markets by opening the market only to larger, sophisticated traders. The CFTC may have embraced this strategy in its recent adoption of R ule 35, which exempts from the CEA swaps transactions between banks, insurance companies, and other relatively wealthy and sophisticated parties. See Exemption of Swap A greements, 17 C.F.R. § 35.1(b)(2) (1996).

307. Such trading is now illegal under 7 U.S.C. $\S 13$ (1994); see also supra notes 88-90 (discussing illegality of off-exchange difference contracts). 
mation arbitrage models of speculative trading. A ccording to these models, speculation shifts risk to those who can bear it most easily (risk hedging) and improves the accuracy of market prices (information arbitrage). The net result has been a strong presumption that speculative trading benefits both traders and markets.

This A rticle challenges the orthodox view that speculation serves efficiency by presenting an alternative theory of speculative trading. The heterogeneous expectations model of speculation rests on the assumption that in a world where information is scarce and costly, rational traders may acquire different subsets of imperfect information that lead them to form differing expectations for the future. These differences of opinion, in turn, can inspire trading between individuals who share an identical willingness to bear risk and an identical willingness to invest in available, but costly, information.

By incorporating the reality of subjective disagreement into the analysis of speculative markets, the heterogeneous expectations approach sheds light on a variety of economic phenomena that have long troubled theorists. Thus, for example, the HE theory can explain the otherwise puzzling association between derivatives speculation and increased systemic risk, ${ }^{308}$ and can illuminate such mysterious economic events as the 1637 tulipmania and the Japanese "bubble economy" of the 1980 's. ${ }^{309}$

The HE model of speculation also offers important insights to legal scholars. Since the days of the common law, a variety of legal rules have discouraged speculative trading both in spot markets and in futures and options. When viewed in isolation, these doctrines can be explained away on other grounds, or dismissed as inefficient vestiges of irrational prejudice. When considered as a whole, however, A merican law reveals a surprisingly strong and well-seasoned structure of rules designed to constrain speculators and to limit their role in the economy. The HE model provides theoretical support for this longstanding pattern of legal hostility by predicting-in direct contrast to the risk hedging and information arbitrage models-that speculative trading inefficiently reduces trader welfare and can distort market prices. The HE model thus offers insights into the efficiency

308. See supra notes 199-201, 276-77 and accompanying text (discussing how HE trading increases risk).

309. See supra notes 206, 228, 231 and accompanying text (describing tulipmania and the possible role of $\mathrm{HE}$ traders); D oes A merica $\mathrm{H}$ ave A Bubble E conomy? No, BUS. WK., May 4, 1998, at 182 (describing the Japanese "bubble economy" of the 1980s and ascribing it to speculation in real estate and other assets). 
of the law in general, and the efficiency of the common law in particular.

Perhaps the greatest contribution of the HE model lies not in its value to scholars, but in its lessons for lawmakers. ${ }^{310}$ In particular, the HE model offers important immediate guidance for lawmakers involved in the impending battle over financial derivatives. O ver the past two decades, a thriving, multi-trillion dollar, off-exchange market in these poorly understood instruments has blossomed in the face of considerable legal uncertainty over the extent to which the CEA applies to financial derivatives. This situation may be about to change as a result of the CFTC's recent announcement that it intends to develop a comprehensive scheme to regulate OTC trading under the CEA. In a sense, the CFTC's initiative is not as novel as it first appears: legal restraints on off-exchange futures and options trading date back at least to the nineteenth century. The CFTC's release has nevertheless inspired champions of derivatives to argue that financial derivatives should be expressly exempted from the CEA .

The heterogeneous expectations approach provides normative support for the CFTC's jurisdictional claim, by illuminating how CFTC oversight of derivatives trading can produce welfare gains by filtering out disagreement-based trading. It also, however, suggests a potentially superior modification to this government gatekeeper ap-

310. The possibility that subjective disagreement can tempt individuals and institutions into accepting risks and squandering resources in the hope of outpredicting each other carries important implications for a variety of contemporary policy issues as well.

For example, the HE model sheds light on the ongoing debate over whether monetary policy should impose a "Tobin tax" on transactions in foreign currencies to stabilize exchange rates, as proposed by Nobel laureate J ames Tobin, see Policy Forum: Sand in the Wheels of International Finance, 105 EcoN. J. 160 (1995) (discussing the Tobin tax); Robert Kuttner, A Tiny Tax M ight Curb Wall Street's H igh Volatility, Bus. W K., M ar. 3, 1997, at 22 (arguing for a Tobin tax to reduce speculation in foreign exchange). The model also sheds light on the value of the mandatory disclosure requirements imposed by federal securities laws. See supra note 306 (describing the implications of HE theory for value of mandatory disclosure). It offers insights, too, into whether individuals diagnosed with potentially fatal illnesses like A ID S should be able to cash in their life insurance before death by selling their policies to viatical companies. See A bbie Crites-L eoni \& A ngellee S. Chen, M oney for L ife: Regulating the Viatical Settlement Industry, 18 J. LEGAL MED. 63, 77 (discussing whether the viatical industry is viable under insurable interest rules); Shanah D. Glick, Comment, A re Viatical Settlements Securities Within the Regulatory Control of the Securities A ct of 1933?, 60 U . CHI. L. REV. 957, 962-63 (1993) (same); see also supra text accompanying notes 97-98 (discussing the insurable interest doctrine). Finally, it offers guidance on whether and how lawmakers ought to regulate "online" gambling. See Claire A nn K oegler, H ere Come the Cybercops 3: B etting on the N et, $22 \mathrm{~N}$ ov A L. REV. 545 (1998) (discussing the regulation of online gambling); supra notes 43-45, 164 and accompanying text (discussing gambling as form of speculation). 
proach: allowing derivatives trading outside the organized exchanges, while declaring off-exchange transactions that cannot be shown to serve a hedging purpose to be legally unenforceable. This alternative recognizes that when the CFTC has determined that an exchangetraded contract serves an important economic purpose, legal enforcement may make sense. O utside the exchanges, however, a rule of unenforceability would force derivatives traders to rely on private ordering, and particularly on reputational capital, to ensure the performance of agreements. This strategy-which mirrors both the common law approach and, perhaps, the OTC market as it exists today-may offer substantial advantages as a means of preserving beneficial risk hedging and information arbitrage while discouraging $\mathrm{HE}$ speculation.

In sum, the HE model offers unique and important insights to lawmakers faced with the task of navigating the shifting shoals of the modern derivatives markets. This observation does not imply that the conventional risk hedging and information arbitrage models are invalid. R isk hedging and information arbitrage trades certainly occur, and with some frequency. The heterogeneous expectations approach does suggest, however, that any discussion of speculation that fails to take account of disagreement-based trading runs the risk of being seriously misleading. A ny full understanding of speculative markets, and any general theory of speculation, must consider the roles of uncertainty and disagreement. 